\title{
REVISION OF THE EARLY OLIGOCENE FLORA OF HRAZENÝ HILL (FORMERLY PIRSKENBERG) IN KNIIŽECÍ NEAR ŠLUKNOV, NORTH BOHEMIA
}

\author{
ZLATKO KVAČEK \\ Charles University in Prague, Faculty of Science, Albertov 6, CZ - 12843 Praha 2, the Czech Republic; \\ e-mail: kvacek@natur.cuni.cz;
}

\section{VASILIS TEODORIDIS}

Charles University in Prague, Faculty of Education, Magdalény Rettigové 4, CZ - 11639 Praha 1, the Czech Republic; e-mail: vasilis.teodoridis@pedf.cuni.cz;

\section{JANA ZAJÍCOVÁ}

Charles University in Prague, Faculty of Science, Albertov 6, CZ - 12843 Praha 2, the Czech Republic;

e-mail: jana.zajicova@natur.cuni.cz.

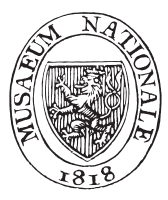

Kvaček, Z., Teodoridis, V., Zajícová, J. (2015): Revision of the early Oligocene flora of Hrazený hill (formerly Pirskenberg) in Knížecí near Šluknov, North Bohemia. - Acta Mus. Nat. Pragae, Ser. B, Hist.-Nat., 71(1-2): 55-102. Praha. ISSN 0036-5343.

\begin{abstract}
The early Oligocene flora of Hrazený hill in Knížecí village at Šluknov, the topic of Erwin Knobloch's diploma thesis, is revised and new elements not previously encountered are included, partly thanks to the use of cuticular analysis: among conifers Pinus cf. rigios (UNGER) EtTingshausen, Taxus engelhardtii KVAČEK and Torreya bilinica SAPORTA et MARION, among angiosperms Laurophyllum medimontanum BỦŽEK et al., Platanus neptuni (ETTINGSHAUSEN) BỦŽEK et al., Engelhardia orsbergensis (WEBER) JÄHNICHEN et al., Betula alboides ENGELHARDT emend. KvaČEK et Walther, B. buzekii Kvaček et Walther, Alnus gaudinii (Heer) Knobloch et KvaČEK, Carpinus roscheri Walther et KVAČEK, C. mediomontana MAI, C. cordataeformis MAI, Ampelopsis hibschii BŮŽEK et al., Hydrangea microcalyx SIEBER, Oleinites hallbaueri (MAI) SAChSE and Saportaspemum cf. occidentale MAYER et MANCheSter. Updated taxonomy has been proposed for several other fossil species including a new combination Parvileguminophyllum haeringianum (ETTINGSHAUSEN) KVAČEK comb. $n$. for the small legume foliage previously called Mimosites. The plant assemblage containing 60 fossil species (1 bryophyte, 5 conifers and 54 angiosperms) has been assigned to the early Oligocene (based on age of the radiometrical dated lava flow immediately covering the fossiliferous diatomite). The reconstructed vegetation type is interpreted as a warm-temperate mixed-mesophytic to broad-leaved deciduous forest with a high proportion of deciduous woody elements. The flora is very similar in its spectrum to adjacent sites of a similar age occurring in Seifhennersdorf in Saxony and Kundratice in the České středohoři Mountains and fits into the previously defined floral assemblage of Seifhennersdorf-Kundratice.
\end{abstract}

Early Oligocene, plant macrofossils, České středohoří Mountains, North Bohemia, palaeoclimate

Received April 23, 2015

Issued October, 2015

\section{Introduction}

Several Palaeogene sites of plant and animal assemblages connected with the magmatic complex of the České středohoří Mountains (Böhmisches Mittelgebirge in German) and adjacent Saxony well known since Sternberg's times have been newly revisited and reviewed in several monographs (e.g. Bůžek et al. 1976, Kvaček and Walther 1995, 1998, 2004, Walther and Kvaček 2007, Kvaček and Teodoridis 2011). All these studies contributed new information on the palaeo-world of this region. In addition to the classic localities we return now to those recovered and studied in detail after the Second World War, situated on the northern periphery of the mountains. A monograph on the early Oligocene flora of Seifhennersdorf-Varnsdorf was published in 2007 (Walther and Kvaček 2007) along with diatoms, fishes and insects. Another site - Hrazený hill (formerly Pirskenberg or Pirsken) in Knížecí near Šluknov has also yielded numerous plant fossils, but so far no new revised data have been available (Text-fig. 1). The plant

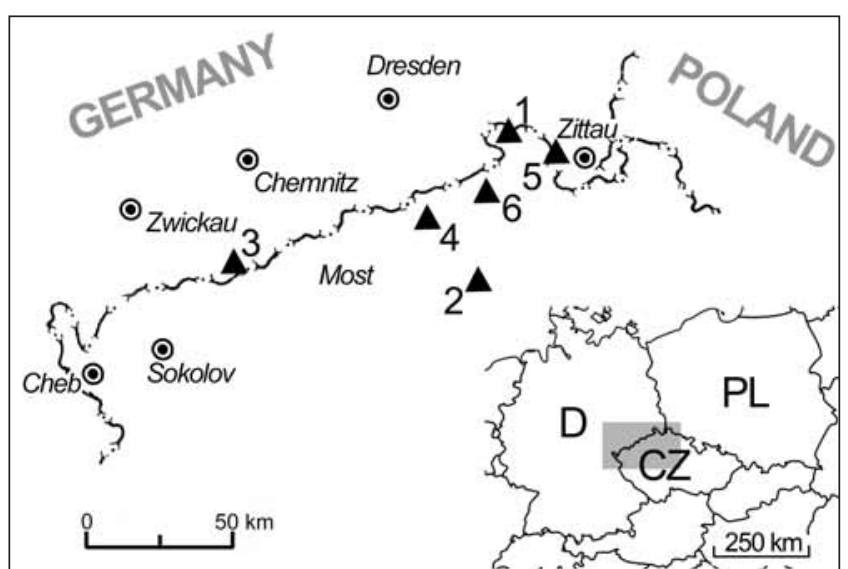

Text-fig. 1. Location of the discussed early Oligocene sites in the northern part of the Bohemian Massif (the Czech Republic and Saxony) - 1. Knížecí, Hrazený hill, 2. Kundratice, 3. Hammerunterwiesenthal, 4. Holý Kluk, 5. Seifhennersdorf, 6. Bechlejovice. 
material was collected from the diatomite layers there and worked out by Knobloch $(1958,1961)$ but the data are outdated and required revision. Beside the original material housed in the National Museum in Prague in 2014 we also sorted out and examined numerous additional fossils collected by Knobloch, which he had left aside for future study but never returned to these collections. Contrary to observations by Knobloch (1961, p. 248), some of the plant remains yielded cuticles that have enabled more precise identification (see Table 1).

Besides fossil plants, co-occurring fishes are known also from this locality (Obrhelová 1961, Gaudant in Bellon et al. 1998, Böhme 2007, Přikryl 2014) and some new specimens were recovered from the collections and offered to our colleague Tomáš Přikryl (Geological Institute CAS, v. v. i., Prague) for a re-evaluation. A few other animal remains (e.g. beetle wing-cases) found at the same time are too incomplete and have not as yet been subjected to detailed study.

\section{Geological setting and age}

The site of Hrazený hill, previously known as Pirskenberg or Pirsken in the village of Knížecí in North Bohemia (Knobloch 1961, Oberhelová 1961) lies ca. 10 km NW from the town of Rumburk and $4 \mathrm{~km} \mathrm{SSW} \mathrm{from} \mathrm{Šluknov} \mathrm{(Plate} \mathrm{21).}$ It lies on the periphery of the České středohoří magmatic complex in Šluknov hills (Bellon et al. 1998), where Hrazený hill is the highest peak at an altitude of $609.7 \mathrm{~m}$ above sea level. The fossiliferous diatomite lies under basaltoid (Kopecký in Knobloch 1959) and tephritic (Bellon in Bellon et al. 1998) lava flows and reaches about $5 \mathrm{~m}$ in thickness. It is not accessible in outcrops but samples are available from old waste heaps in Knížecí village following an unsuccessful search for lignite in the $19^{\text {th }}$ century.

The first reports on fossil plant remains from this area were published by Weise (1890). Further geological and palaeontological data were obtained during geological mapping by Herrmann and Beck (1897) who also provided a list of recovered fossil plants identified by H. Engelhardt from Dresden. This collection was not illustrated nor described in detail. Another site of fossiliferous diatomite is situated near the village of Lipová (formerly Heinspach) mentioned by Herrmann and Beck (1897), where also fossil plants occur (see Jeremies 2006).

Knobloch (1959, p. 102-103) reported on his geological mapping in the area of Hrazený hill and the village of Knížecí in the following text (shortened translation from Czech): "The freshwater Tertiary deposit was not visible in the complete section. The thickness is very variable (from $0.3 \mathrm{~m}$ to 3-5 $\mathrm{m}$ on average). It starts with fine-grained green-brown tuffitic clay and continues upwards as variegated clay with interbeds of sandy and clayey bedded diatomite. It also includes a black layer of bituminous clay $0.2 \mathrm{~m}$ thick, which was obviously interpreted as poor quality lignite. The layers are not laid horizontally and incline towards the basin center at maximum angles of ca. $50^{\circ}$ or less. The richest fossiliferous layers are represented by bedded reddish to light brown diatomite with abundant fossil flora showing regular bedding similar to the diatomite at Bechlejovice and Varnsdorf. The Tertiary complex ends with an eruption of basaltoid magma. L. Kopecký who kindly assessed thin sections of the magmatic rock from Hrazený hill identified it as common basalt sensu stricto. However, the existence of 2-3 flows cannot be ruled out."

An extensive correlative study of the České středohoři Mountains by Bellon et al. (1998) assigned the flora of Knížecí to the early Oligocene and concluded that the nearest plant assemblages were described from the slightly older sites of Seifhennersdorf-Varnsdorf and Kundratice (Kvaček and Walther 1998, Walther and Kvaček 2007). Bellon (in Bellon et al. 1998) attempted radiometric dating of several sites in the České středohoří magmatic complex by a detailed petrological and geochemical study. He carried out K-Ar dating on whole rock samples and obtained data suggesting an age from 23.7 to $38.3 \mathrm{Ma}$. He also analyzed one sample of a lava flow immediately covering the diatomite layer at Hrazený hill and an age of $29.5 \pm 1.5 \mathrm{Ma}$ was suggested. Böhme (2007, p. 189) estimated the ectothermic vertebrate fauna from Knížecí also to be early Oligocene.

\section{Material and methods}

The collecting activities of Erwin Knobloch between the years 1956 - 1957 on waste dumps left after old mining attempts in the village of Knížecí (5058'33'N, 14²4'51 'E) provided almost all the study material (Knobloch 1958, 1959, 1961, Oberhelová 1961). A few plant specimens were added by Kotlaba and Bartoš later (collections in the National Museum in Prague). The exact position and lithology of the fossiliferous diatomite at Knížecí was described in detail by Knobloch $(1958,1959,1961)$ who also personally excavated most of the material studied. Some of the layers are thinly bedded, fine grained and quite hard; the mechanical preparation to reveal complete plant impressions was obviously difficult because many specimens show traces left by a knife (Knobloch 1961, pl. 8, fig. 3 etc.). In addition to the thinly bedded diatomite we also noticed in the collections samples of coarser diatomite facies with accumulations of disintegrated Tetraclinis twigs and fragmentary plant fossils. The majority of the specimens studied represents flat leaf impressions, occasionally infructescences (Platanus neptuni, Alnus) and catkins (Alnus), fruits (Acer, Craigia, etc.) or seeds (Carpolithes spp.). In rare cases a detached stamen and fruitlets of Platanus neptuni were recovered. Conifer needles and a smaller proportion of leaf fossils are impressions/ compressions with preserved coaly material and cuticle on the surface. The material is heavily oxidized. We used a shortened maceration procedure, in which the leaf fragments were first treated in diluted HF, rinsed in water and then in diluted $5 \% \mathrm{KOH}$. The coaly material was mostly naturally oxidized and could be dissolved without any additional maceration. The cuticles were then transferred into a drop of water on a slide, embedded in glycerol and sealed with a cover glass bordered with nail varnish.

The illustrated specimens and cuticle preparations have been transferred to the collections of the palaeontological department of the National Museum in Prague (numbers prefixed by NM), duplicate material is housed in the Czech Geological Survey, Prague (numbers prefixed by EK and without numbers) together with unidentified or fragmentary 
Table 1. Current taxonomic assignements compared with the designations of Knobloch (1961).

\begin{tabular}{|c|c|}
\hline Present treatment & Knobloch (1961) \\
\hline Muscites sp. & Muscites sp. \\
\hline \multicolumn{2}{|l|}{ Pinus cf. rigios } \\
\hline Taxodium dubium & Taxodium distichum miocenicum \\
\hline Tetraclinis salicornioides & Libocedrus salicornioides \\
\hline \multicolumn{2}{|l|}{ Taxus engelhardtii } \\
\hline \multicolumn{2}{|l|}{ Torreya bilinica } \\
\hline Liriodendron haueri & Liriodendron haueri \\
\hline Laurophyllum mediomontanum & Salix longa \\
\hline Laurophyllum sp. & $\begin{array}{l}\text { Laurus princeps }+ \text { Laurophyllum } \mathrm{sp} .+ \\
? \text { Benzoin attenuatum }+\mathrm{cf} . \text { Laurus } \\
\text { primigenia }\end{array}$ \\
\hline Daphnogene cinnamomifolia & Cinnamomum scheuchzeri \\
\hline Smilax weberi & Smilax grandifolia \\
\hline "Typha" latissima & Typha latissima \\
\hline Poacites sp. & Poacites cf. aequalis \\
\hline Platanus neptuni & $\begin{array}{l}\text { Ceratopetalum bilinicum }+ \text { Comptonia } \\
\text { difformis p.p. }\end{array}$ \\
\hline Cercidiphyllum crenatum & Cercidiphyllum crenatum \\
\hline Ampelopsis hibschii & $\begin{array}{l}\text { Platanus } \text { cf. aceroides }+ \text { Vitis sp. }+ \text { Zelkova } \\
\text { ungeri p.p. }\end{array}$ \\
\hline Phaseolites sp. 1 & Leguminosites sp. p.p. \\
\hline Phaseolites sp. 2 & Leguminosites sp. p.p. \\
\hline Phaseolites sp. 3 & ? Cassia sp. \\
\hline Phaseolites sp. 4 & Dalbergia bella \\
\hline Parvileguminophyllum haeringianum & Mimosites cf. haeringiana \\
\hline Rosa lignitum & $\begin{array}{l}\text { Rosa sp. }+ \text { Engelhardia macroptera p.p. }+ \\
\text { ? Rhus pyrrhae }\end{array}$ \\
\hline Crataegus pirskenbergensis & Crataegus pirskenbergensis \\
\hline Ulmus fischeri & $\begin{array}{l}\text { cf. Ulmus braunii var. plurinervia }+ \text { Zelkova } \\
\text { ungeri p.p. }\end{array}$ \\
\hline \multicolumn{2}{|l|}{ Zelkova zelkovifolia } \\
\hline Celtis pirskenbergensis & $\begin{array}{l}\text { Celtis begonioides }+ \text { Celtis begonioides var. } \\
\text { pirskenbergensis }\end{array}$ \\
\hline Comptonia difformis & Comptonia difformis p.p. \\
\hline Engelhardia orsbergensis & Myrica lignitum p.p. \\
\hline Engelhardia macroptera & Engelhardtia macroptera \\
\hline Carya fragiliformis & Carya serraefolia \\
\hline Cyclocarya sp. & $\begin{array}{l}\text { Cyclocarya cyclocarpa + Juglans (Carya) } \\
\text { bilinica p.p. }\end{array}$ \\
\hline Betula alboides & Betula cf. dryadum \\
\hline Betula buzekii & Betula prisca \\
\hline Alnus gaudinii & $\begin{array}{l}\text { ? Pterocarya denticulata }+\mathrm{cf} . \text { Alnus } \\
\text { kefersteinii }\end{array}$ \\
\hline Alnus kefersteinii & Alnus sp. + Betula sp.p.p. \\
\hline Carpinus grandis & Carpinus orientalis \\
\hline Carpinus roscheri & Betula brongniartii \\
\hline \multicolumn{2}{|l|}{ Carpinus cordataeformis } \\
\hline Carpinus mediomontana & Carpinus cf. neilreichii \\
\hline
\end{tabular}


Table 1. [continued]

\begin{tabular}{|c|c|}
\hline Populus zaddachii & Populus zaddachii \\
\hline Salix sp. & Populus rottensis \\
\hline Toxicodendron herthae & Rhus herthae \\
\hline Acer angustilobum & Acer cf. angustilobum \\
\hline Acer palaeosaccharinum & Acer palaeosaccharinum \\
\hline \multicolumn{2}{|l|}{ Acer integrilobum } \\
\hline Acer sp. & Acer sp. \\
\hline Craigia bronnii & Pteleaecarpum bronnii \\
\hline Cornus studeri & Cornus studeri + Rhamnus graeffii \\
\hline Hydrangea microcalyx & Paliurus thurmannii \\
\hline Oleinites hallbaueri & Myrica lignitum p.p. + cf. Ilex rottensis \\
\hline \multicolumn{2}{|c|}{ Saportaspermum cf. occidentale } \\
\hline \multicolumn{2}{|c|}{ Dicotylophyllum cf. heerii } \\
\hline Dicotylophyllum sp. 1 & $\begin{array}{l}\text { Juglans acuminata }+ \text { Ficus arcinervia }+\mathrm{cf} \text {. } \\
\text { Rhus pteleaefolia }\end{array}$ \\
\hline Dicotylophyllum sp. 2 & Leguminosites sp. p.p. \\
\hline Dicotylophyllum sp. 3 & Juglans (Carya) bilinica p.p. \\
\hline Dicotylophyllum sp. 4 & Sibirea rottensis \\
\hline Dicotylophyllum sp. 5 & Aesculus cf. palaeocastanum \\
\hline Dicotylophyllum sp. 6 & Celastrus persei \\
\hline Carpolithes sp. 1 & ? Pisonia eocenica \\
\hline Carpolithes sp. 2 & Carpolithes sp. \\
\hline
\end{tabular}

specimens. The cuticle preparations transferred to the National Museum bear the same collection numbers as the macrofossil, from which they were taken, but with additional letters a-x. Most of the specimens described by Knobloch (1961) were available and re-examined here, except for some which were obviously lost, e.g. illustrated fruits of Craigia, Engelhardia, foliage of Rosa and some impressions of angiosperms.

\section{Systematic palaeontology}

The general characteristics of the flora were described by the late Erwin Knobloch who submitted it as a diploma thesis (Knobloch 1958) and later published it in an abbreviated form (Knobloch 1961). The cuticle analysis allowed the addition of several new elements not recognized in Knobloch's study and treated here in detail anew. The nomenclature published by Knobloch (1961) was rectified and notes on affinities of some other specimens were included according to present knowledge. English translations of the descriptions given in Czech by Knobloch (1958) are used in selected cases and new descriptions are provided, where necessary. Extensive synonym lists have been avoided and references to the basionyms and previous monographs are quoted instead. The chapter "Material studied" refers to the specimens investigated personally by the present authors. For the systematic arrangement of taxa newly proposed classifications and linear sequence of extant gymnosperms and angiosperms (Christenhusz et al. 2011, Reveal 2012) have been adopted.

\section{Bryophytes}

\section{Muscites BRONGNIART}

\section{Muscites sp.}

Pl. 1, Fig. 1-3

1961 Muscites sp. (Hypnum heppii HeER); Knobloch, p. 249 , pl. 10, fig. 1 .

Delicate impressions of sterile moss gametophyte plants monopodially branched and covered with leaflet appendages less than $1 \mathrm{~mm}$ in size showing thin midribs.

Discussion. The preservational state of the examined moss remains is quite poor, anatomical and morphological details that would allow a more precise identification are not visible. Similar but better preserved are impressions published as Hypnum lycopodioides WeBER by Weyland (1937, p. 69, pl. 9, fig. 1-3) from the upper Oligocene of Rott, Rhineland, and housed in the collections of the Geological-Palaeontological Institute of the University in Bonn, which we could examine personally. The branching pattern seems to correspond to both fossil records. Before the Rhineland material is revisited no definite judgment can be made about the material from Knížecí.

Material. Fragmentary moss gametophytes, NM-G2888, NM-G11514 and a few un-numbered EK specimens. 


\section{Conifers}

\section{Pinaceae LindLey}

\section{Pinus Linnaeus}

Pinus (subgen. Pinus) cf. rigios (Unger) EtTIngshausen

$$
\text { Pl. 1, Fig. 4-5 }
$$

? 1866 Pinus rigios (Unger) Ettingshausen, p. 41, pl. 13, fig. 11-12.

Fragmentary pine needles in ternate fascicle, ca. 0.5-0.7 $\mathrm{mm}$ thick, trigonal in cross section, the maximum preserved length $45 \mathrm{~mm}$, sheath permanent, $2 \mathrm{~mm}$ long.

Discussion. Fossil pine needles are rare in the Palaeogene deposits of the České středohoří Mountains (e.g. Žichov and Matrý - see Ettingshausen 1866, Akhmetiev et al. 2009, as Pinus rigios (Unger) EtTingshausen). Some previously reported needle-like fossils assigned by Menzel (1901) to pines from Suletice-Berand turned out to represent monocots (Kvaček and Walther 1995). The occurrence of pine pollen noted in several cuticle preparations confirms pine stands nearby the site of Knížecí during the time when the fossiliferous diatomite was deposited.

$P$. rigios was originally described from the lower Miocene of Bílina in the North Bohemian Basin, where it is associated with seed cones of $P$. engelhardtii Menzel. A more accurate determination of the present material is not really possible because of its fragmentary nature. Co-occurring seed cones, which would more reliably characterise this pine, have not been so far recovered. The needles can be referred to subgen. Pinus and may represent the same species as those recovered at Žichov and Matrý.

M a t e ri a 1. Two needle fascicles, EK 237a, b, 238.

\section{Cupressaceae RichaRd ex BARTLING sensu lato}

\section{Taxodium RICHARD Taxodium dubium (STERnberg) HeER}

P1. 1, Fig. 6-7, Pl. 2, Fig. 1

1823 Phyllites dubius Sternberg, tent., p. 39, pl. 36, fig. 3.

1855 Taxodium dubium (SternBerg) HeEr, p. 49-50, pl. 17, fig. 5-15.

1961 Taxodium distichum miocenicum HeER; Knobloch, p. 250 , pl. 2, fig. 8, pl. 10, fig. 2 .

1976 Taxodium dubium (STERnBerG) HeER; Kvaček, p. 290, fig. 5-7.

The Taxodium twigs from Knížecí were described by Knobloch (1958) as follows (translated from Czech): "Leaves are acicular, entire-margined and acuminate at the apex, with a clearly distinct midrib. They are attached very regularly at angles of ca. $45^{\circ}$ on either side of the twig axis. The longest twig reaches $12 \mathrm{~cm}$." The twigs are on the average $60 \mathrm{~mm}$ long and 7 to $19 \mathrm{~mm}$ wide. Kvaček (1976, fig. 7b) was able to prepare the cuticle from one of the twigs from Knížecí previsouly published by Knobloch (1961, pl. 2, fig. 8, as Taxodium distichum miocenicum HEER) and interpreted it as ordinary epidermal structure of Taxodium dubium with stomata mostly transversally orientated to the leaf length.

D i s c u s s i on. Similar twigs from Seifhennersdorf exhibited only poorly preserved epidermal structure (Walther and Kvaček 2007). According to Kunzmann et al. (2009), the European Oligocene populations of Taxodium belong to the same fossil species as occurring in the European Neogene and differ only in details of the cone scales.

M a t e ri a l. Leafy twigs, NM-G2815a, b with cuticle, NM-G2892, EK numerous specimens without number.

\section{Tetraclinis MASTERS Tetraclinis salicornioides (UNGER) KVAČEK}

Pl. 1, Fig. 8-10, Pl. 2, Fig. 2-3

1847 Thuites salicornioides UnGER, p. 11, pl. 3, fig. $1-4$.

1961 Libocedrus salicornioides (Unger) HEER; Knobloch, p. 251, pl. 1, fig. 12, pl. 14, fig. 9.

1989 Tetraclinis salicornioides (UNGER) KVAČEK, p. 48, pl. 2, fig. 3, 10, 12, 14.

Knobloch (1958, as Libocedrus salicornioides) described some of the recovered remains as follows (translated from Czech): "Leaves on the twigs strongly adpressed, so that they look as if fused, forming the twig itself. They are approximately rhombic in form. The wider end bears a blunt tip, or it has projections on both sides and a medial small depression, where the next leaf is attached, or it is semicircular with six small projections. The leaves are scaly and show 2-6 (mostly 3) longitudinal ribs. They are verticillate and vary in size, the smallest being $2 \mathrm{~mm}$ long, the longest $12 \mathrm{~mm}$." The newly obtained epidermal structure matches other records of this conifer from North Bohemia (see e.g. Kvaček 1989, Kvaček et al. 2014).

D iscussion. Numerous specimens at hand have yielded cuticle structure and one specimen removed from rock shows even the typical stomatal topography of this species. It widely differs from the xeromorphic disposition of stomata in the narrow areas sunk between leaves in $T$. brachyodon (BRONGNIART) MAI et WALTHER (Kvaček et al. 2000).

M a teria 1. Short fragments of twigs, many isolated segments, NM-G2810, NM-G8584, NM-G11495b, c, NM-G11496a, b, NM-G11507, EK 240-245, further specimens not numbered.

\section{Taxaceae GraY}

\section{Taxus LinNaEus Taxus engelhardtii KvAČEK}

Pl. 1, Fig. 11-13, Pl. 2, Fig. 4-5

1976

Taxus engelhardtii KVAČEK, p. 294, fig. 8-9.

Needle-like leaves isolated, flattened, univeined, only reaching $1 \mathrm{~mm}$ in width and 6-12 $\mathrm{mm}$ in length. Epidermal 
structure shows adaxially rectangular cells with straight anticlines. Abaxial cuticle reflects two stomatal bands and three non-stomatal zones; medial non-stomatal zone papillate, lateral only beside stomata covered with low papillae. Stomatal apparati longitudinally arranged, monocyclic, composed of a pair of sunken guard cells and usually four papillate subsidiary cells.

D i s c u s s i on. Knížecí is the third site, from which proven foliage of Taxus engelhardtii has been recorded. The first occurrence is from the type locality at Kundratice, where whole twigs are preserved (Kvaček and Walther 1998). Thanks to the very typical epidermal structure we can record the presence of this conifer based on separated needles with very particular papillate monocyclic stomata on the lower leaf side. In addition to the type locality it was only recorded in the upper Oligocene of Enspel in western Germany (Köhler and Uhl 2014). The needles of Cephalotaxus parvifolia (WALTHER) KVAČEK et WALTHER are morphologically indistinguishable but differ decidedly by the absence of papillae on the stomata (Kvaček and Wather 1998, Walther and Kvaček 2007). According to Spjut (2007) Taxus engelhardtii is very similar to the extant T. mairei (LEMÉE et H. LÉveILlÉ) S.Y. Hu ex T.S. LIU native in subtropical laurophyllous forests of southern China.

Materia 1. Isolated needles with cuticle structure, NM-G11481a, b, NM-G11482a, b, NM-G11501a-c.

\section{Torreya ARNOTT}

\section{Torreya bilinica SAPORTA et MARION}

Pl. 1, Fig. 14-16, P1. 2, Fig. 6-8

1866 Sequoia langsdorfii ETTINGSHAUSEN (non (BRONGNIART) HEER), p. 39, pro parte, pl. 13, fig. 9.

1876

1984 Torreya bilinica SAPORTA et MARION, p. 221. Torreya bilinica SAPORTA et MARION; Kvaček, p. 478 , fig. 5-6.

Needles linear, up to $20 \mathrm{~mm}$ long, $1.5 \mathrm{~mm}$ wide, apex bluntly acute, with a single broad midrib, epidermis prosenchymatous, cells straight-walled, very narrow, ca. $10-15 \mu \mathrm{m}$ wide and more than $250 \mu \mathrm{m}$ long, with blunt cuneate ends, abaxially papillate near stomatal bands, with two stomatal bands much more strongly papillate, ca. 120 $\mu \mathrm{m}$ wide, elliptic outlines of stomata barely visible under the thick papillate cover, stomata monocyclic, longitudinally aligned, otherwise scattered, not forming lines, guard cells sunken, with thinly demarcated elongate stomatal pit surrounded by a ring of ca. 8 subsidiary cells forming the broadly oval apparatus up to $80 \mu \mathrm{m}$ wide and $110 \mu \mathrm{m}$ long.

$\mathrm{D}$ is c u s s i o n. The fossil record of needles of Torreya from the Czech Republic was reviewed by Kvaček (1984) who used evidence from epidermal anatomy to confirm the view of Saporta and Marion (1976) that the fragmentary twig from the Oligocene site of Žichov in North Bohemia, which had been misidentified as Sequoia by Ettingshausen (1866), should belong to Torreya in spite of the aberrant blunt apex of the needles. Similar rounded apices as in other occurrences of Torreya bilinica at Seifhennersdorf and also at Knížecí appear in ancient representatives of the genus (Torreya gracilis FLORIN, 1958) while the Neogene records (e.g. Kvaček et al. 2008) share the cuspidate apex with all living species (Florin 1948, Li et al. 2001). The Palaeogene of North Bohemia (Žichov - Kvaček 1984, Kundratice - Kvaček and Walther 1998, Matrý - Akhmetiev et al. 2009, Roudníky Kvaček et al. 2014, Knížecí - present paper) and Saxony (Kleinsaubernitz - Walther 1999, Seifhennersdorf - Walther and Kvaček 2007) is the limited area of this species, which is not known elsewhere.

M a t e ria l. Fragmentary needles with cuticle structure, NM-G11508a, b, NM-G11509a, b, NM-G11510a, b, all with cuticle, EK 246.

\section{Magnoliaceae JussieU}

\section{Liriodendron LINNAEUS Liriodendron haueri ETTINGSHAUSEN}

Pl. 3, Fig. 1-4, P1. 6, Fig. 1

1869 Liriodendron haueri EtTINGSHAUSEN, p. 9, pl. 41, fig. 10-10b.

1961 Liriodendron procaccinii UnGER; Knobloch, p. 273, pl. 7, fig. 1, 3 .

1961 Styrax sp.; Knobloch, p. 288, pl. 14, fig. 4.

Leaves broadly ovate with four lobes arising from a point one third of the blade width or only shallowly bilobate, leaf blade 41-82 mm long and 21 - ca. $90 \mathrm{~mm}$ wide, base widely cuneate, petiolate, petiole maximum $50 \mathrm{~mm}$ long. Midrib strong and straight, secondary veins arising at an angle of $40-50^{\circ}$, opposite or alternate, every second joined by a broken tertiary vein to the next vein above and then looping. Lowermost pairs sending fine outer loops towards the margin. Tertiary venation forms polygonal fields. Mesophyll tissue with small lens-shaped secretory cells, cuticles smooth, the abaxial surface with scattered stomata openings, otherwise cell structure poorly preserved.

D i s c u s s i o n. One aberrant leaf impression with only two shallow lobes was referred to Styrax by Knobloch (1961) but a similar leaf impression from Markvartice was assigned to Liriodendron on account of its epidermal anatomy (Bůžek et al. 1976, pl. 3, fig. 8). Of the available names for fossil species of Liriodendron (see e.g. Archenegg 1894) we prefer here Liriodendron haueri ETTINGSHAUSEN rather than $L$. procaccinii UNGER (selected by Knobloch 1958, 1961) because the former name is based on a leaf impression from the Oligocene of North Bohemia (see Hably et al. 2001, p. 27, pl. 20, fig. 2, Akhmetiev et al. 2009, pl. 13, fig. 3) and was accepted by the previous authors dealing with other Palaeogene occurrences of Tulip tree foliage in this region (see e.g. Bůžek et al. 1976, Walther 1998). L. procaccinii is a common designation for fossil foliage of Liriodendron distributed mainly in Europe during the late Neogene (see Saporta and Marion 1876 - Meximieux, Knobloch 1998 Willershausen). L. haueri differs from L. procaccinii in acute lobes contrary to mostly rounded lobes in the Italian Neogene populations (Knobloch 1998, p. 14). Revision of the latter species type material from Senigallia, Italy (Massalongo and Scarabelli 1859, Kustatcher et al. 2014) is required. Two extant species differ in the surface sculpture of the abaxial 
cuticle. The leaves in L. tulipifera L. from E and SE North America are abaxially smooth, in L. chinense (HEMSLEY) SARGENT from eastern China and Vietnam are papillate. In this respect our material looks to be similar to L. tulipifera.

It is noteworthy that in living species of Tulip tree the fruitlets survive in large quantities after the season under the trees while foliage readily decomposes over the winter. This is perhaps a reason why leaf impressions are less common than fruitlets in the fossil state (e.g., at Markvartice - Bůžek et al. 1976, Roudníky - Kvaček et al. 2014). This is however not the case at the Knížecí site, where no fruitlets have yet been recovered.

Materia 1. Leaf impressions, NM-G2856a-f with cuticle, NM-G2859, NM-G2997, NM-G8591.

\section{Lauraceae JuSSIEU}

\section{Laurophyllum GÖPPERT \\ Laurophyllum medimontanum BŮžEK, HOLÝ et KVAČEK}

\section{Pl. 4, Fig. 1-2, Pl. 6, Fig. 2}

Salix longa AL. Braun; Knobloch, p. 252, pl. 8, fig. 9.

1976

Laurophyllum medimontanum BŮŽEK, HoLÝ et KVAČEK, p. 98, pl. 9, fig. 1-5, pl. 16, fig. 1-6, pl. 17, fig. 1-2.

Leaves elongate, entire-margined, 70-110 $\mathrm{mm}$ long and $15 \mathrm{~mm}$ wide, midrib straight, gradually narrowing towards the base apex, secondary veins thin, long ascending and looping, intersecondaries ending in tertiary veins that form a polygonal network. Abaxial cuticle moderately papillate, reflecting brachyparacytic stomata.

D i s c u s s i o n. This fossil species was at first compared with Laurophyllum villense (WEYLAND et KILPPER) KVAČEK, 1971 but later recognized as an independent fossil species (Bůžek et al. 1976), widely distributed at Markvartice, outside the Bohemian Massive also found in Hesse (Flörsheim - Kvaček 2004, as Laurophyllum cf. villense).

Material studied. Leaf impressions, partly with cuticles, NM-G2863, NM-G2995, NM-G2996, NM-G3002a-c, NM-G3003.

\section{Laurophyllum sp.}

\section{Pl. 4, Fig. 3-7, Pl. 6, Fig. 3}

1961 Laurus princeps HeER; Knobloch, p. 275, pl. 10, fig. 4.

1961 Laurophyllum sp.; Knobloch, p. 276, pl. 10, fig. 8. 1961 ? Benzoin attenuata HEER; Knobloch, p. 276.

1961 cf. Laurus primigenia UNGER; Knobloch, p. 276, pl. 10 , fig. 7 .

Leaves elongate to oval, 48-106 mm long, 17-19 mm wide, entire-margined, venation camptodromous to brochidodromous lauroid, secondaries irregularly disposed.

D is cussion. Lauroid leaf impressions described by Knobloch (1961, p. 275-276) are mostly preserved without clearly discernible cuticle structure and thus their identification to species level is very imprecise. One specimen (NM-G2885) yielded a very thinly cutinized abaxial epidermis, which is similar to the material from Markvartice assigned to Magnoliaceae (?) gen. et sp. by Bůžek et al. (1976).

Material st udied: Leaf impressions, NM-G2884, NM-G2885a, b, NM-G2890a, b, NM-G2977, NM-G2890a, b, NM-G11998a, b, EK 258.

\section{Daphnogene UNGER \\ Daphnogene cinnamomifolia (BRONGNIART) UNGER}

Pl. 5, Fig. 1-4, Pl. 6, Fig. 4

Phyllites cinnamomifolia Brongniart in Cuvier, p. 359, pl. 11, fig. 12.

Daphnogene cinnamomifolia (BRONGNIART) UNGER, p. 424.

1961 Cinnamomum scheuchzeri (HEER) Frentzen; Knobloch, p. 276, pl. 1, fig. 7, pl. 10, fig. 9.

Knobloch (1961) identified cinnamomoid leaves from Knížecí according to the slender form as Cinnamomum scheuchzeri from the middle Miocene of Öhningen and described them as follows: (translated from Czech) "Leaves lanceolate, entire. Midrib straight, conspicuous. Basal veins running near the margin. In the leaves' lower two thirds they end and connect with the secondary veins, which depart from the midrib. Basal veins are connected with the leaf margin by tertiaries either perpendicular or oblique or broken. In the leaves' upper third secondary veins arise from the midrib and interconnect by loops. Higher-order venation is formed by a reticulum of polygonal fields." The leaves vary in size from very small, $21 \mathrm{~mm}$ long and $13 \mathrm{~mm}$ wide to slightly broader, ca. $40 \mathrm{~mm}$ wide, fragmentary in length. The mesophyll tissue contains numerous lens-shaped secretory cells. The recently obtained structure of the adaxial cuticle shows polygonal cells with straight anticlinale walls or occasionally only very shallowly wavy, the abaxial cuticle is densely hairy and the trichomes are only $5 \mu \mathrm{m}$ thick, very narrow, and ca $100 \mu \mathrm{m}$ long.

Discussion. The record of Daphnogene from Knížecí is similar in epidermal patterns to those known from other Oligocene localities in Europe (e.g. Kvaček and Knobloch 1967, Bůžek et al. 1976). The abaxial epidermal structure, namely long narrow trichomes, corresponds to that described from the Oligocene material of Markvartice (Kvaček in Bůžek et al. 1976). As any connection between Palaeogene foliage with fruits of Cinnamomum has not yet been proven, we continue including the above fossil species in the fossil genus Daphnogene.

Material studied: Leaf impressions-compressions, NM-G2811, NM-G2851a, b, NM-G8600, NM-G11497, NM-G11498, NM-G11499, NM-G11500, NM-G11513, EK 247, 248, partly with cuticles.

\section{Smilacaceae Ventenat}

Smilax LinNaEus

Smilax weberi WESSEL

Pl. 5, Fig. 9-10 

pl. 2, fig. 1.

1961 Smilax grandifolia (UnGER) HeER; Knobloch, p. 251 , pl. 13 , fig. 7 , pl. 15 , fig. 9 .

Leaves entire-margined, blade 37 to ca. $65 \mathrm{~mm}$ long, 29 to $34 \mathrm{~mm}$ wide, ovate, at base more or less cordate, towards the apex gradually narrowing. Midrib straight, with one or two arch-like basal veins on either side, the outermost interconnected by large fields. Tertiary venation consists of polygonal fields of variable size.

$\mathrm{D}$ is cussion. The newly studied type material from the upper Oligocene of Rott (Winterscheid et al., personal communication) confirms the correct identification of the Knížecí material, as suggested above.

Material studied: Leaf impression, NM-G8581a, b, NM-G8608, EK 249.

Monocotyledonae inc. fam.

\section{"Typha" latissima A. BRAUN}

Pl. 5, Fig. 5-6, 8

1961

Typha latissima A. BRAUN; Knobloch, p. 251, pl. 12, fig. 7.

Strap-like fragmentary foliage with parallel venation attaining a mean width of $10-15 \mathrm{~mm}$, parallel veins of two orders; between slightly thicker veins $1 \mathrm{~mm}$ apart run 2-4 thinner veins. Cross veins almost perpendicular, $1.5-2 \mathrm{~mm}$ apart.

Discussion. The generic affinity of the foliage described above is open and due to fragmentary nature of fossils uncertain.

Material studied: Leaf fragments, NM-G8593, EK 250-254.

\section{Poacites Heer (non Schlotheim) Poacites sp. div.}

\author{
Pl. 5, Fig. 7
}

1961 Poacites cf. aequalis EtTINGSHAUsen; Knobloch, p. 252.

Strap-like fragmentary leaves with parallel venation, attaining a meanwidth 6 to $17 \mathrm{~mm}$. Thicker veins irregularly interspaced with thinner veins.

Discussion. The affinity of these fragments to monocots is obvious but otherwise not determinable more exactly. Heer (1855) was the first who connected the fossil genus Poacites correctly with angiosperms, contrary to previous authors, who had applied it mostly to lycopod foliage (see Andrews 1955, 1970). Hence the name Poacites in the sense of Heer (1855) requires conservation.

Material studied: Leaf impressions, NM-G3001, EK 255-257.
Platanaceae LeSTIBoudois ex DUMORTIER

\section{Platanus LinNaEUS \\ Platanus neptuni (EtTINGSHAUSEN) BŮžEK, HolÝ et KVAČEK}

Pl. 6, Fig. 5, P1. 7, Fig. 1-7

1866 Sparganium neptuni EtTingShausen, p. 31, pl. 7, fig. 9-15.

1961 Comptonia diforme (STERNBERG) BERRY; Knobloch, p. 257, pro parte, pl. 3, fig. 9 left [NM-G2830b].

1961 Ceratopetalum bilinicum ETTINGSHAUSEN; Knobloch, p. 277, pl. 10, fig. 12.

1967 Platanus neptuni (ETTINGSHAUSEN) BŮŽEK, HolÝ et KVAČEK, p. 205, pl. 1-4.

Fragmentary leaves obovate, $37-42 \mathrm{~mm}$ long and 7-11 mm wide, on the margin widely blunt regularly toothed, partly entire, venation semicraspedodromous, partly eucamptodromous, adaxial cuticle composed of polygonal cells with regularly sinuate anticlines, abaxial cuticle showing large anomocytic stomata and compound trichome bases dispersed on abaxial leaf side. Female infructescence ca. $10 \mathrm{~mm}$ in diameter composed of narrow fruitlets projected by a short style out of the infructescence outline. Isolated stamen obconical, with two longitudinal pollen sacks and a terminal thickened cap. Strap-like stipules parallel-veined, cut at the base.

D i s c u s s i o n. The single available infructescence was wrongly interpreted as belonging to Comptonia by Knobloch (1961). All the other organs fit within the characteristics recognized previously in this species (Bůžek et al. 1976, Kvaček and Manchester 2004). The affinity of these foliage fragments is confirmed by the epidermal structure showing large anomocytic stomata with widely open ledges and compound trichome bases (Pl. 6, Fig. 5) recorded in the previous studies.

Material studied: Fragmentary leaves, partly with cuticle structure, NM-G2887, NM-G11503a, b, NM-G11504a, b, EK 259-262; female infructescence, NM-G2830b; isolated stamen, NM-G11998c; stipule, EK 263.

\section{Cercidiphyllaceae VAN TIEGHEM}

\section{Cercidiphyllum SIEBOLD et ZUCCARINI Cercidiphyllum crenatum (UNGER) R. BROWN}

$$
\text { P1. 7, Fig. 8-9 }
$$

1850

1935 Cercidiphyllum crenatum (UNGER) R. BROwn, p. 575 , pl. 68 , fig. $1,6,8-10$.

1961 Cercidiphyllum crenatum (UNGER) R. BROwN; Knobloch, p. 274, pl. 15, fig. 1, 3, 4, 11.

Leaves of Cercidiphyllum were characterized by Knobloch (1958, translation from Czech) as follows: "Leaf blade cordate to elliptical, widest in the lower half. Leaf margin crenulate, base cordate to rounded. 1-3 basal veins run on either side of the main vein. They are broken in places, 
where other veins emerge. A row of thinner veins start from basal veins and run towards the leaf margin, they loop and send veinlets into marginal teeth. Tertiary venation consists of variously sized fields". Leaf blades attain 30 to $64 \mathrm{~mm}$ in length and 21 to ca. $50 \mathrm{~mm}$ in width.

D i s c u s s i o $n$. The typical variation in leaf form from narrower elliptical to rounded and broadly cordate is developed in the plant assemblage of Knížecí in the same way as in some other records of this species in the České středohoří Mountains, e.g. at Bechlejovice (Kvaček and Walther 2004).

Mat e rial st ud i ed: Leaf impressions, NM-G8580, NM-G8595, NM-G8599, NM-G11492, EK 264-266.

\section{Vitaceae JussiEU}

\section{Ampelopsis MichauX Ampelopsis hibschii BŮžEK, KVAČEK et WALTHER}

Pl. 8, Fig. 1-6

1961 Platanus cf. aceroides GÖPPERT; Knobloch, p. 277, pl. 10, fig. 3 [NM-G2891].

1961 Vitis sp.; Knobloch, p. 288, pl. 8, fig. 3 [NM-G2869].

1961 Zelkova ungeri KovÁTs; Knobloch, p. 270, pro parte, pl. 7, fig. 7 [NM-G2855].

1981 Ampelopsis hibschii BŮŽEK, KVAČEK et WALTHER, p. 127, pl. 1-6, text-fig. 1-7.

Knobloch (1958) described the material as follows (translated from Czech): "Base slightly cordate, leaf probably palmately veined and trilobate. From the base three basal veins and secondaries emerge, which are slightly wavy and end in the marginal teeth. Tertiary veins are perpendicular or oblique between secondaries and form variable large fields. Petiole $18 \mathrm{~mm}$ long" (under Platanus cf. aceroides). "A rounded leaf, probably shallowly trilobed (leaf margin and apex not preserved). Base cordate, basal veins slightly arched, secondaries also wavy. Tertiaries forked between secondaries producing a broken line. Quaternary venation composed of a network of polygonal areoles" (under Vitis sp.). Morphologically variable fragmentary foliage attains 38 to ca. $78 \mathrm{~mm}$ in length and 68 to ca. $80 \mathrm{~mm}$ in width.

D i s c us sion. Besides large fragmentary leaves and a petiolate base assigned to Platanus $\mathrm{cf}$. aceroides, Vitis and partly Zelkova by Knobloch (1961), we recovered from the additional fragmentary material from Knížecí leaf apices with a separated tip, a diagnostic feature of $A$. hibschii (Bůžek et al. 1981). We assume that other fragmentary leaf fossils apparently belonging to Vitaceae, as listed in the synonymy, belong to this species known from Bechlejovice, Kundratice and elsewhere. One impression assigned to Zelkova (Knobloch 1961, pl. 7, fig. 7) may represent a leaflet of a compound leaf only rarely encountered in this species (e.g. Walther in Mai and Walther 1978, pl. 7, fig. 2-3, as Ampelopsis sp.).

Material studied: Leaf impressions, NM-G2855, NM-G2869, NM-G2891, EK 267-271, more specimens not numbered.

\section{Leguminosae Jussieu}

\section{Phaseolites UNGER \\ Phaseolites sp. 1}

Pl. 9, Fig. 4

1961 Leguminosites sp.; Knobloch, p. 279, pro parte, pl. 5, fig. 15 .

Leaflets entire-margined, oval, symmetric to slightly oblique, rounded at base, rounded at apex, attaining at maximum $30 \mathrm{~mm}$ in length and $22 \mathrm{~mm}$ in width, sessile to very shortly petiolulate, venation very fine, dense, eucamptodromous.

D iscussion. Similar legume leaflets have been described from Bechlejovice (Kvaček and Walther 2004, p. 31, pl. 13, fig. 5-7, as Leguminosites sp. 1) and Kundratice (Kvaček and Walther 1998, p. 20, pl. 10, fig. 9-10, as Leguminosae gen. et sp., forma 1-2). We use the fossil taxon Phaseolites for such legume foliage instead of Leguminosites, which is typified by carpological material (Bowerbank 1840).

Material studied: Leaflet impressions, NM-G2839, EK 273-275.

\section{Phaseolites sp. 2}

$$
\text { P1. 9, Fig. 7-8 }
$$

1961 Leguminosites sp., Knobloch, p. 279, pro parte, pl. 8, fig. 10 .

Leaflets entire-margined, ovate, almost sessile, obliquely attached and asymmetric at base, fragmentary in length, $20 \mathrm{~mm}$ wide.

D i s c u s s i o n. Knobloch (1961) stated that he did not find any reference to similar legume foliage in the literature and we share his opinion.

Material studied: Impressions of isolated leaflets, NM-G2983, NM-G2868, EK 276.

\section{Phaseolites sp. 3}

P1. 9, Fig. 5

1961 ? Cassia sp.; Knobloch, p. 280, pl. 11, fig. 5.

Fragmentary compound leaf, with leaflets entiremargined, ovate (?), obviously belonging to but detached from a long straight petiole, sessile, showing two basal veins starting asymmetrically from the rounded base.

D is cus s ion. Knobloch (1961) believed that this incomplete fossil remain may resemble Dalbergia rottensis WeYland (1937, p. 98, pl. 11, fig. 11-14, text-fig. 39). Due to its very fragmentary nature the generic affinity of this single specimen is very uncertain.

Material studied: Incomplete leaf impression, NM-G2903. 


\section{Phaseolites sp. 4}

Pl. 9, Fig. 6

Dalbergia bella HeER; Knobloch, p. 280, pl. 10, fig. 10 .

Leaflet sessile, entire-margined, emarginate, obovate, $24 \mathrm{~mm}$ long, $12 \mathrm{~mm}$ wide, midrib thin, straight, secondary veins eucamptodromous, steep, closely spaced, occasionally forked near margin, tertiary venation reticulate.

D i s c u s s i on. The generic affinity of this single leaflet obviously belonging to legume foliage is uncertain.

Material studied: Leaflet impression, NM-G2862a, b.

\section{Parvileguminophyllum Herendeen et Dilcher}

1990 Parvileguminophyllum HERENDEEN et DILCHER, p. 348 .

Type: Parvileguminophyllum georgianum (BERRY) HERENDEEN et DiLCHER.

\section{Parvileguminophyllum haeringianum (ETTINGSHAUSEN) KVAČEK comb. nov.}

\author{
P1. 9, Fig. 1-3
}

1853 Mimosites haeringiana EtTingshausen, p. 92, pl. 30, fig. 23-37 (basionym).

1961 Mimosites cf. haeringiana EtTINGSHAUSEN; Knobloch, p. 280, pl. 12, fig. 1, pl. 14, fig. 8.

2010 Mimosites haeringiana EtTINGSHAUSEN; Meller, p. 140-141, pl. 41, fig. 7-8, pl. 42, fig. 1-9.

Lectotypus selected here: leaflet illustrated by Ettingshausen (1853, pl. 30, fig. 31) and Meller (2010, pl. 42, fig. 6a, b), GBA 1853/001/0173/8 at the Geologische Bundesanstalt, Vienna (Häring, Lower Oligocene).

Linear basally asymmetrical leaflets of delicate legume foliage, blunt at the apex and with asymmetrical basal venation, 11-19 $\mathrm{mm}$ long and $4 \mathrm{~mm}$ wide.

Discussion. Previous records of this legume, elsewhere often occurring as compound leaves (e.g. at Kundratice - Kvaček and Walther 1998, Bechlejovice Kvaček and Walther 2004, as Mimosites haeringianus) were described from the České středohoří Mountains under the designation Mimosites haeringianus ETTINGSHAUSEN (Kvaček and Walther 1998, 2004). Because the generic name Mimosites is based on pods (Bowerbank 1840), a newly introduced fossil genus Parvileguminophyllum for morphologically similar foliage of uncertain affinities (Herendeen and Dilcher 1990) is given preference. The late Eocene flora of Florissant includes very similar leaf impressions known as Prosopis linearifolia (LESQUEREUX) MACGinities (1953, p. 126, pl. 46, fig. 1, 5 (non pl. 73, fig. 7); Meyer 2003, p. 105, fig. 95). A more precise comparison has not yet been done.

Material studied: Leaflet impressions, NM-G8583, NM-G8592, NM-G11487, EK numerous not numbered.

\section{Rosaceae JussiEU}

\section{Rosa LinNaeus \\ Rosa lignitum HEER}

Pl. 10, Fig. 1-9

1869 Rosa lignitum HeER, p. 99, pl. 30, fig. 33.

1961 Rosa sp.; Knobloch, p. 278, pl. 8, fig. 4.

1961 Engelhardtia macroptera (BRONGNIART) ETTINGSHAUSEN; Knobloch, p. 311, pro parte, only pl. 4, fig. 4.

1961 ? Rhus pyrrhae UNGER; Knobloch, p. 287, pl. 8, fig. 2, pl. 11, fig. 11 .

Leaflets mostly ovate, small-sized, 19-54 mm long, 22-19 mm wide, crenulate to finely denticulate on margin, sub-sessile, venation dense, semi-craspedodromous. Knobloch (1961) characterized the material very briefly: (translated from German): "Leaflets oval, simple dentate, at base slightly asymmetrical, teeth apically orientated, secondary veins steep and entering the marginal teeth."

D i s c u s s i o n. Knobloch (1961) refered to a monograph of fossil roses, predicted to have been accomplished by the Czech expert Dr. Ivan Klášterský but which was never finished, and therefore treated the remains of roses very superficially. Detached leaflets of similar type and crenulate margin as well as complete compound leaves had been since known from other localities in the České středohoři Mountains, e.g. Kundratice (Kvaček and Walther 1998), Roudníky (Kvaček et al. 2014) and in particular Bechlejovice (Kvaček and Walther 2004).

Material studied: Leaflet impressions, NM-G2865, NM-G2871, NM-G2876b, EK 277-286.

\section{Crataegus Linnaeus \\ Crataegus pirskenbergensis KNOBLOCH}

P1. 10, Fig. 10-11

1961 Crataegus pirskenbergensis KNOBLOCH, p. 278, pl. 8, fig. 7-8.

Leaves broadly ovate, divided into 3 lobes, 32 to $78 \mathrm{~mm}$ long, 26 to ca. $60 \mathrm{~mm}$ wide, finely serrate. For a more detailed description and diagnosis see Knobloch (1961).

D i s c u s s i o n : Similar leaf impressions have also been recorded in the Oligocene floras at Bechlejovice (Kvaček and Walther 2004), Roudníky (Kvaček et al. 2014) and probably at Seifhennersdorf (Walther and Kvaček 2007).

Material st ud i ed: Leaf impressions, NM-G2861a, b, NM-G2867 a, b.

\section{Ulmaceae MirbeL}

\section{Ulmus LINNAEUS \\ Ulmus fischeri HEER}

P1. 11, Fig. 1-4
Ulmus fischeri HeER, p. 57, pl. 57, fig. 1-3. 

STANDFEST; Knobloch, p. 270, pl. 1, fig. 3, 5.

1961 Zelkova ungeri KovÁts; Knobloch, p. 270, pl. 1, fig. 2, pl. 7, fig. 4, 7 .

Leaves shortly petiolate, lamina broadly ovate to ovate-elongate or oval, 13-45 mm long, 15-31 mm wide, simple or double dentate. Midrib straight, up to 11 secondary veins, straight to slightly bent, partly forked, tertiary veins perpendicular to secondary veins.

D i s c u s s i o n . Knobloch (1961) incorrectly assigned some coarsely simple dentate elm leaves to Zelkova which differs in having less densely spaced secondary veins. These simple dentate leaves fall into the normal variation of Ulmus fischeri foliage which is widely distributed in the Oligocene of the České středohoří Mountains (e.g. Bechlejovice Kvaček and Walther 2004) and Saxony (Walther and Kvaček 2007).

Mat e rial st u d i ed: Leaf impressions, NM-G2804, NM-G2807, NM-G2808, NM-G2809, NM-G2855, NM-G2858, EK 287, some other fragments not numbered.

\section{Zelkova SPACH \\ Zelkova zelkovifolia (UNGER) BŮŽEK et KOTLABA}

\section{Pl. 11, Fig. 5}

1844

Ulmus zelkovifolia UNGER, p. 94, pl. 24, fig. 7 right, 9-13.

1845 Ulmus zelkovifolia UNGER; Unger, p. 95, pl. 26, fig. 7 (lectotype).

1963 Zelkova zelkovifolia (UNGER) BŮŽEK et KotLABA in KotlabA, p. 59, pl. 3, fig. 7-8.

Two leaf fragments showing coarsely dentate margins and which prove the occurrence of this fossil species at Knížecí.

Discussion. In general both fragments match a much more diversified record from Kundratice and Bechlejovice (Kvaček and Walther 1998, 2004). They differ from the simple dentate elm foliage, e.g. Ulmus fischeri HEER, in having fewer secondary veins, although in some critical cases the differentiation might be arbitrary.

Material studied: Leaf impressions, EK 288, 289.

\section{Celtidaceae LINK}

\section{Celtis TOURNEFORT \\ Celtis pirskenbergensis (KNOBLOCH) KVAČEK et WALTHER}

Pl. 12, Fig. 1-6

1961 Celtis begonioides GÖPPERT var. pirskenbergensis KNOBLOCH, p. 273, pl. 6, fig. 3, 5, 8 (holotype).

1961 Celtis begonioides GöPPERT; Knobloch, p. 273, pl. 6, fig. 9, pl. 12, fig. 4 .

2006 Celtis sp.; Radoň et al., p. 101, pl. 5, fig. 5-7.

2007 Celtis pirskenbergensis (KNOBLOCH) KVAČEK et WALTHER; Walther and Kvaček, p. 101, pl. 7, fig. $1-8$, text-fig. $4 \mathrm{a}-\mathrm{c}$.
Leaves short petiolate, ovate to elongate, up to $64 \mathrm{~mm}$ long and 16 to ca. $45 \mathrm{~mm}$ wide, oblique at base, on margin coarsely serrate, slightly asymmetrical. Three basal veins arise from below the lamina base at sharp angles. Outer basal veins ascend upwards to about one half of the leaf length and then loop with higher almost straight secondary veins. Tertiary veins are perpendicular (translated from Knobloch 1958, 1961, emended).

D is c u s s i o n. Kvaček and Walther (in Walther and Kvaček 2007) merged all specimens of Celtis recovered from Knížecí and elsewhere in the Palaeogene of North Bohemia and Saxony into a single fossil species $C$. pirskenbergensis (KNOBLOCH) KVAČEK et WALTHER. The same large sized kind of foliage also occurs at the other Oligocene sites Holý Kluk (Radoň et al. 2006) and Seifhennersdorf (Walther and Kvaček 2007). We agree with this treatment leaving separately other fossil species known from the Miocene, which clearly differ morphologically (see e.g. Němejc et al. 2003).

M a t e ri a 1 s t u di ed: Leaf impressions, NM-G2850a, b (holotype), NM-G2851a, b, NM-G2852, NM-G2853a, b, NM-G2979, NM-G8600.

\section{Myricaceae RICHARD ex KunTH}

\section{Comptonia L'HÉRITIER Comptonia difformis (STERNBERG) BERRY}

\author{
Pl. 6, fig. 6, Pl. 13, Fig. 1-8
}

1961 Comptonia difformis (STERnBERG) BERry; Knobloch, p. 257 pro parte (non infructescence on pl. 3, fig 6 left = Platanus neptuni), pl. 3, fig. 4-7, 9-10, pl. 12, fig. 6 , pl. 15, fig. 8 .

Leaves coriaceous, variable in size from minute specimens hardly attaining $21 \mathrm{~mm}$ in length and $5 \mathrm{~mm}$ in width to larger, up to $80 \mathrm{~mm}$ long, acuminate, at base abruptly narrowing into a short petiole. Leaf lamina pinnately dissected into triangular rounded segments (lobes) at base reaching usually to the midrib, opposite to alternate, variable in size and form in this respect matching the living Comptonia peregrina L. Segments at apex usually blunt, but also mucronate; $2-8$ perpendicular secondaries entering the lobes, three of them are usually thicker than the others and stretch to the margin from the straight midrib. They are connected by oblique tertiary veins that form a polygonal field (Knobloch 1958, translated from Czech, emended). The newly obtained epidermal structure is very fragmentary. Adaxial cuticle is smooth and shows outlines of cells ca. 20-25 $\mu \mathrm{m}$ in diameter with almost straight to wavy anticlines. Abaxial cuticle is extremely thin, hairy, and shows rounded short uniseriate stalks ca. $12 \mu \mathrm{m}$ in diameter and even disc-shaped glandular trichomes up to $50 \mu \mathrm{m}$ in diameter.

D is cussion. The occurrence of Comptonia in the European Palaeogene is connected with two fossil species, C. difformis later widely spread in the Neogene and the more xeromorphic, small-leaved C. dryandrifolia BRONGNIART (= C. schrankii (STERnBERG) BERRY). The population from 
Knížecí corresponds to $C$. difformis morphologically, as stated by Knobloch (1961), as well as in epidermal anatomy. In general the epidermal structure matches that obtained from leaves of Comptonia difformis from the upper Oligocene of Kleinsaubernitz (Walther 1999).

Material studied: Leaf compressions-impressions, NM-G2826, NM-G2827, NM-G2829, NM-G2831, NM-G2986, NM-G2987, NM-G2988， NM-G2989, NM-G2830, NM-G11502a, b, EK 290-302, numerous specimens not numbered.

\section{Juglandaceae A. RichARD ex KUNTH}

\section{Engelhardia LeSChENAUX ex BLUME Engelhardia orsbergensis (WESSEL et WEBER) Jähnichen, MaI et WaLther}

P1. 6, Fig. 9, Pl. 14, Fig. 1-5

1856

Banksia orsbergensis WESSEL et WEBER, p. 146, pl. 25, fig. 9a-d.

1961 Myrica lignitum (UnGer) SAPORTA; Knobloch, p. 256 , pro parte, pl. 1, fig. 13 , pl. 2, fig. 10 , pl. 2 , fig. 3 , pl. 12, fig. 5 .

1977 Engelhardia orsbergensis (WESSEL et WEBER) JäHNICHEN, MAI et WALTHER, p. 326, pl. 38-49, text-fig. 1-3.

Leaflets narrow elongate, 34-55 $\mathrm{mm}$ long and $13 \mathrm{~mm}$ wide, straight to slightly bent, minutely widely dentate, base asymmetrical. The epidermal structure rarely preserved on delicate leaflets, showing rounded stalks of peltate trichomes and sunken stomata.

D is c u s s i on. The material from Knížecí was partly identified as Myrica lignitum (Knobloch 1961, p. 256, morphotype 1, cf. Dryandroides acuminata). All specimens studied correspond morphologically to the variation in Engelhardia orsbergensis as known from the type locality Orsberg in the Rhineland (Jähnichen et al. 1977, Winterscheid and Kvaček 2014) and other occurrences in the České středohoří Mountains (e.g. Kvaček and Walther 1995, 1998). Similar leaflets, but lacking epidermal structure, have been described from the early Oligocene site Häring in Austria under several fossil species, e.g. Rhus prisca ETTINGSHAUSEN and $R$. juglandogene EtTINGSHAUSEN.

Material studied: Leaflets, NM-G2805, NM-G2824, NM-G8582, NM-G11511a, b, EK 303-311, some more not numbered.

\section{Engelhardia macroptera (BRONGNIART) UNGER}

$$
\text { Pl. 14, Fig. } 5
$$

Carpinus macroptera BRONGNIART, p. 48, pl. 3, fig. 6 .

1866 Engelhardia macroptera (BRONGNIART) UNGER, p. 52, pl. 16, fig. 9-12.

1961 Engelhardia macroptera (BRONGNIART) UNGER; Knobloch, p. 261, pl. 4, fig. 4, 10.

Fruits are rounded nuts attached to a four-winged involucrum. The main three wings are triveined, the medial wing is longer, rounded at the apex, the very short forth wing envelopes the fruit basally. Venation consists of elongate fields along the main veins, forming smaller areoles towards the lobe margin (translated and emended from Knobloch 1958).

D is c us sion. The fruits of Engelhardia occur only rarely in the Knížecí plant assemblage and match other occurrences in the European Tertiary (see Mai in Jähnichen et al. 1977).

Material studied: Fragmentary involucres, EK 312.

\section{Carya NutTal \\ Carya fragiliformis (STERnberg) KVAČEK et WALTHer}

$$
\text { P1. 14, Fig. } 70
$$

Phyllites fragiliformis SternBerg, p. 42, index iconum, pl. 50, fig. 1.

1961 Carya serraefolia (GÖPPERT) KRÄUSEL; Knobloch, p. 260, pl. 9, fig. 9, 12, pl. 11, fig. 1-3.

2007 Carya fragiliformis (STERNBERG) KVAČEK et WALTHER; Walther and Kvaček, p. 110, pl. 11, fig. $1-3$, pl. 23 , fig. $8-10$, text-fig. 6 b.

Leaflets ovate-oval, 36-115 mm long and 26-36 mm wide, on margin double serrate, base decurrent, asymmetrical, midrib straight or slightly bent, distinct, secondary veins at almost right angle at leaflet base, higher up at a more steep angle. Often forked near margin, sometime twice, particularly those from near the leaflet base, tertiary veins running perpendicularly or slightly oblique, higher-order venation areolate (Knobloch 1958, translated from Czech, modified).

D i s c u s s i o n s: The material assigned by Knobloch (1961) to Carya represents variable foliage, which is partly difficult to distinguish from leaflets of Cyclocarya, as described below.

Material studied: Impressions of leaflets, NM-G2878, NM-G2878, NM-G2894, NM-G2895, NM-G2978, EK 313-316.

\section{Cyclocarya ILJINSKAYA Cyclocarya sp.}

$$
\text { P1. 14, Fig. } 8
$$

1897 Pterocarya cyclocarpa D.H.R. SCHLECHTENDAL, p. 20, pro parte, pl. 4, fig. 1-3.

1961 Cyclocarya cyclocarpa (D.H.R. SCHLECHTENDAL) KNOBLOCH, p. 262, pl. 15, fig. 5-7.

1961 Juglans (Carya) bilinica A. BRAun; Knobloch, p. 258 , pl. 4, fig. 5-9.

Leaflets lanceolate to narrow ovate, cuneate at base, 33-70 mm long, 14-22 mm wide, margin fine serrate, midrib bent, secondary veins widely regularly spaced, looping near margin, semicraspedodromous, tertiary veins forming polygonal fields (Knobloch 1961, emended).

Discussion. Knobloch (1961) was the first who corrected Iljinskaya's combination of Cyclocarya "cycloptera" 
for this species (Iljinskaya 1953) to "cyclocarpa". The morphology of foliage corresponds in general with the records from Bechlejovice (Kvaček and Walther 2004) and Seifhennersdorf (Walther and Kvaček 2007). So far no associated fruits of Cyclocarya have been recovered in the České středohoří Mountains and thus an open nomenclature is applied (see also Walther and Kvaček 2007).

Material studied: Impressions of leaflets, NM-G2833， NM-G2836， NM-G2837， NM-G2929, NM-G2932, NM-G2984, NM-G8589, EK 317-319.

\section{Betulaceae GrAY}

\section{Betula LinNAEUS \\ Betula alboides ENGELHARDT}

Pl. 15, Fig. 1-2

1870

Betula alboides ENGELhardt, p. 16, pl. 3, fig. 22-23.

1961 Betula cf. dryadum BRONGNIART; Knobloch, p. 266, pl. 14, fig. 3 .

Leaves broadly ovate or oval, rounded at base, $26-30 \mathrm{~mm}$ long, 13-22 mm wide, margin simple to double dentate, midrib thin, secondary vein in 6-7 pairs, craspedodromous, at medium acute angles $\left(47-62^{\circ}\right)$.

D i s c u s s i on. The smaller leaves of birch recovered at Knížecí and assigned by Knobloch (1961) to Betula dryadum BRONGNIART match the newly studied lectotype of $B$. alboides from Seifhennersdorf (Walther and Kvaček 2007). However, we do not follow use of this fossil species also for larger forms, as suggested by Walther and Kvaček (2007), and apply a separate species B. buzekii for them, as explained below.

Material studied: Leaf impressions, NM-G8588, EK 324-327.

\section{Betula buzekii KVAČEK et WALTHER}

Pl. 15, Fig. 3-4

1961 Betula prisca EtTINGSHAUSEN; Knobloch, p. 265, pl. 2, fig. 5, 7, pl. 5, fig. 1-13, pl. 10, fig. 11.

1998 Betula buzekii KvaČEK et Walther, p. 9, pl. 3, fig. 8-10, text-fig. 5, 13.1.

Leaves long petiolate, ovate to ovate elongate, ca $40 \mathrm{~mm}$ long and $25 \mathrm{~mm}$ wide, on the apex acute to acuminate, at base rounded to subcordate or slightly decurrent, margin simple to double serrate; midrib straight or slightly bent, secondary veins diverging at angles of (25-) 30-40 (-45) $)^{\circ}$, mostly opposite, 7-9, 3-5 $\mathrm{mm}$ apart, craspedodromous, tertiary veins slightly bent between secondary veins (Knobloch 1961, as Betula prisca, emended).

Discussion. The prevailing birch foliage from Knížecí was assigned by Knobloch (1961) to Betula prisca ETTINGSHAUSEN. It corresponds well in gross leaf morphology to the newly established species B. buzekii KVAČEK et WALTHER (1998) based on another early Oligocene population from Kundratice.
Material studied: Leaf impressions, NM-G2821, NM-G2822, NM-G2823, NM-G2838, NM-G2841, NM-G2842， NM-G2843， NM-G2844， NM-G2845, NM-G2846, NM-G2847， NM-G2848， NM-G2849, NM-G2882, NM-G2980， NM-G2982， NM-G2994, NM-G4839, NM-G4840, NM-G4841, EK 320-323, some more not numbered.

\section{Alnus Miller \\ Alnus gaudinii (HEER) KNOBLOCH et KVAČEK}

\section{Pl. 15, Fig. 5-7}

1859

Rhamnus gaudinii HeER, p. 79, pl. 124, fig. 4-15, pl. 125, fig. 1, 7, 13 .

1961 ? Pterocarya aff. denticulata (GöPPERT) SCHLECHTENDAL; Knobloch, p. 264, pl. 11, fig. 10.

1961 cf. Alnus kefersteinii (GöPPERT) Unger; Knobloch, p. 267, pl. 2, fig. 9, 11.

1976 Alnus gaudinii (HeER) KNOBLOCH et KVAČEK, p. 33, pl. 6, fig. 1, 3, pl. 7, fig. 1, 5, pl. 13, fig. 4, pl. 15 , fig. $1-4,7-8,10-11,15,17$, pl. 16 , fig. $1-5$, pl. 19 , fig. 15 , pl. 20 , fig. 10 , text-fig. 11-12.

Leaves oblong to narrow ovate, incomplete in length, 23-30 mm wide, on margin simple serrate, teeth blunt, almost glandular, quite widely spaced, secondary veins eucamptodromous-semicraspedodromous, at angles of 30$35^{\circ}$, partly looping, tertiary veins oblique or perpendicular, prominent, higher-order venation distinct.

D i s c u s s i o n. Knobloch (1961) compared some alder leaf impresions from Knížecí with Alnus kefersteinii, which is based on generative organs, and erroneously compared some leaf impressions with the Juglandaceae (as ? Pterocarya aff. denticulata (Göppert) SchlechtendAl). Similar foliage occurs e.g. at Kundratice, from where the epidermal structure has also been obtained (Kvaček and Walther 1998).

Material studied: Leaf impressions-compressions, NM-G8603a, b, EK 328-341.

\section{Alnus kefersteinii (GÖPPERT) UNGER}

\section{Pl. 15, Fig. 8-9}

1838 Alnites kefersteinii GöPPERT, p. 364, pl. 41, fig. $1-19$.

1847 Alnus kefersteinii (GÖPPERT) UNGER, p. 115, pro parte, pl. 33, fig. 1-3.

1961 Betula sp.; Knobloch, p. 267, pro parte, pl. 5, fig. 14 (non pl. 10, fig. 8 = indeterminable object).

1961 Alnus sp.; Knobloch, p. 268, pl. 2, fig. 3, 12.

Alder infructescences 14-21 mm long, 10-12 mm wide, catkins containing in situ pentaporate pollen of Alnus.

$\mathrm{D}$ is cussion. Both female and male reproductive organs are assigned to the same fossil species following the original Göppert's (1838) concept. The same type of A. gaudinii foliage has been found in association with similar infructescences at many other Oligocene sites, e.g. Kundratice (Kvaček and Walther 1998) and Seifhennerdorf (Walther and Kvaček 2007). 
Material studied: Infructescences and catkins with pollen in situ, NM-G2819, NM-G2820, NM-G2840, EK 342-343.

\section{Carpinus LinNaEus Carpinus grandis UNGER}

Pl. 16, Fig. 1

1850 Carpinus grandis UNGER, p. 409.

1961 Carpinus orientalis GAUDIN et STROzzI; Knobloch, p. 269, pl. 13, fig. 6, pl. 14, fig. 1.

Leaves ovate, $27-35 \mathrm{~mm}$ long, $12-18 \mathrm{~mm}$ wide, fine simple or double serrate on margin, subcordate to rounded at base, midrib straight, secondary veins craspedodromous, parallel, densely spaced, tertiary veins not preserved.

D i s c u s s i o n. The above described hornbeam foliage may not be placed without question in the above relatively formal taxon, as it is accompanied at various sites either by fruits of the $C$. betulus type or the $C$. orientalis type described below.

Material studied: Leaf impressions, NM-G8587, NM-G8601, EK 345-348, 358.

\section{Carpinus roscheri KVAČEK et WALTHER}

\section{Pl. 16, Fig. 2-3}

1961 Betula brongniartii ETTINGSHAUSEN; Knobloch, p. 266, pl. 2, fig. 1-2, 6.

2007 Carpinus roscheri KVAČEK et WALTHER; Walther and Kvaček, p. 105, pl. 10, fig. 1-5, text-fig. c-e.

Leaves broadly ovate, 45-65 mm long, 31-39 wide, base rounded to subcordate, margin coarsely double serrate, midrib almost straight, thick, secondary veins regularly parallel, at angles of $50^{\circ}$, in leaf base up to $70^{\circ}$, opposite or slightly alternate, in 10 pairs ca. $6 \mathrm{~mm}$ apart.

$\mathrm{D}$ i s c u s s i o n. Foliage similar to the newly described fossil species $C$. roscheri from Seifhennersdorf (Walther and Kvaček 2007) was recovered by Knobloch (1961, as Betula brongniartii) also at Knížecí. As at Seifhennersdorf this type of foliage is accompanied by involucres, assigned to Carpinus cordataeformis and differing from the $C$. orientalis - type in shallow lobed margins.

Material studied: Leaf impressions, NM-G2816a，b，NM-G2817, NM-G2818, NM-G2821, NM-G2825, NM-G2981, EK 344.

\section{Carpinus cordataeformis MAI}

$$
\text { P1. 16, Fig. 6-7 }
$$

1963 Carpinus cordataeformis MAI, p. 55, pro parte, pl. 4, fig. 1-2, text-fig. 6a-b.

Involucrum elongate, very shallow bluntly dentate on one side partly covering the fruit, and almost entire on the opposite side.
D is cussion. Similar fruits accompany leaves of C. roscheri at Seifhennersdorf (Walher and Kvaček 2007).

Material studied: Involucres, NM-G2995b, EK 349.

\section{Carpinus mediomontana MAI}

P1. 16, Fig. 4-5

1961 Carpinus neilreichii KovÁts; Knobloch, p. 268, pl. 12, fig. 3 .

1963 Carpinus cordataeformis MAI, p. 55, pro parte, pl. 4, fig. 3-4, text-fig. 6d.

1978 Carpinus mediomontana MAI; Mai and Walther, p. 68 , pl. 6, fig. 6 , pl. 28, fig. 21-27.

According to Knobloch (1958, translated from Czech) the involucres are asymmetric, not divided into lobes, on one side entire, on the opposite coarsely dentate with double denticulate larger teeth, venation palmate, including up to 7 basal primary veins, thicker stretching to the teeth, thinner veinlets ending before margin at about $2 / 3$ of the involucre, higher order veins perpendicular or slightly oblique.

D i s c u s s i o n. Similar involucres and fruits have been found at Seifhennersdorf associated with foliage of $C$. grandis (Walther and Kvaček 2007). At Knížecí they occur quite often and clearly prevail over Carpinus cordataeformis.

Material studied: Involucres, partly with fruits, NM-G2998b, NM-G8586, EK 350-356, 405, some more not numbered.

\section{Salicaceae MirbeL}

\section{Populus Linnaeus Populus zaddachii HeER}

$$
\text { P1. 17, Fig. 4-6 }
$$

1859 Populus zaddachii HeER, p. 307

1869 Populus zaddachii HeER; Heer, p. 30, pl. 5, pl. 6, fig. 1-7, pl. 12, fig. 1c.

1961 Populus zaddachii HeER; Knobloch, p. 254, pl. 12, fig. 9, pl. 13, fig. 5, pl. 14, fig. 2, 7.

According to Knobloch (1958, translated from Czech), the leaves are broadly ovate elongate to cordate with crenulate-serrate margin, at base rounded to slightly cordate; the midrib is straight extending into a flattened petiole up to $2 \mathrm{~mm}$ broad and accompanied by two lateral primaries, from which thin secondary veins arise. They attain a size ranging from $36 \mathrm{~mm}$ to more than $120 \mathrm{~mm}$ in length and 29-73 $\mathrm{mm}$ in width.

D i s c u s s i o n. Knobloch (1961, p. 254) stressed the large variation in leaf morphology of $P$. zaddachii and compared it with the living $P$. balsamifera $\mathrm{L}$. This fossil species typical of the European Oligocene (see Mai and Walther 1978) is known from several other Oligocene sites in North Bohemia and Saxony (see Walther and Kvaček 2007).

Material studied: Leaf impressions, NM-G2990, NM-G2991，NM-G8578，NM-G8579a，b，NM-G8590, NM-G8604a, b, EK 359. 


\section{Salix LinNAEUS \\ Salix sp.}

Pl. 17, Fig. 1-3

1961

Populus rottensis WeYLAND; Knobloch, p. 254, pl. 1, fig. 9, pl. 11, fig. 9 .

Leaves narrow lanceolate, up to $85 \mathrm{~mm}$ long and 16-18 $\mathrm{mm}$ wide, base rounded with thick petiole, margin glandular serrate. Midrib thick, secondary veins quite steep, camptodromous to semicraspedodromous, bent along the margin, lower pair almost opposite. Tertiary veins reticulate.

D i s c u s s i on. Knobloch (1961) followed Weyland (1937) who suggested similar material from Rott to belong to Populus and assigned also his fragmentary impressions to Populus, mainly because of lacking intersecondary veinlets. In our opinion these leaf impressions are more comparable with foliage of willows, described from other Oligocene sites as Salix varians GÖPPERT with preserved epidermal anatomy important for distinguishing both genera (see Walther in Mai and Walther 1978, Walther and Kvaček 2007).

Mate rial st ud i ed: Leaf impressions, NM-G2806, NM-G2893a, b, EK 360a, b, more fragments not numbered.

\section{Anacardiaceae LindLEY}

\section{Toxicodendron MILLER}

\section{Toxicodendron herthae (UNGER) KVAČEK et WALTHER}

$$
\text { P1. 18, Fig. } 1
$$

Rhus herthae UNGER, p. 6 (non pl. 14, fig. 21= Fagus sp.).

$1850 \quad$ Rhus herthae UnGER; Unger, p. 473.

1961 Rhus herthae UNGER; Knobloch, p. 286, pl. 13, fig. 4.

1998 Toxicodendron herthae (UNGER) KVAČEK et WALTHER, p. 27, pl. 15, fig. 3-8, text-fig. 13.16.

Leaflets oval, very fragmentary, on the apex bluntly acute, on margin irregularly bluntly coarsely serrate, midrib straight, distinct, secondary veins bent, craspedodromous, accompanied by single intersecondaries, not reaching the margin, tertiary veins oblique. Resin ducts have been recorded in the mesophyll during maceration. Epidermal structure not preserved except distinct and dense wavy cuticle striation.

Discussion. Fragmentary specimens clearly correspond with the more complete material from Bechlejovice, Kundratice and other sites of North Bohemia and Saxony, from where this well recognizable accessory element has been reported (Kvaček and Walther 1998, 2004). For nomenclatural details see Kovar-Eder et al. (2004).

Material studied: Impressions of fragmentary leaflets, NM-G2916a, b, EK 361.

\section{Sapindaceae JussiEU}

\section{Acer LinNAeus Acer angustilobum HeER}

P1. 6, Fig. 7, P1. 18, Fig. 2-3
Acer angustilobum HeER, p. 57, pl. 117, fig. 25a, pl. 118, fig. 4-9.

1961 Acer cf. angustilobum HeER; Knobloch, p. 285, pl. 9 , fig. 4 , pl. 11, fig. 4 .

Leaves deeply tricuspidate, blades 19 to more than $65 \mathrm{~mm}$ long and 22-74 mm wide, lobes of almost the same width, with subparallel margins, widely simple dentate. Abaxial cuticle fine papillate.

Discussion. Maple leaves with a prominently double dentate middle lobe have usually been assigned to Acer palaeosaccharinum STUR but transitional forms connect them with typical Acer angustilobum with only simple dentation on the main lobe. Both fossil morpho-types are connected with transition as expressed in the Procházka's monographs (Procházka 1952, Procházka and Bůžek 1975) by establishing infraspecific taxa (Acer palaeosaccharinum forma subplatanoides PROCHÁzKA et BƯŽEK and forma subdasycarpoides PROCHÁzKA et BƯŽEK). We apply the same system as in Knobloch (1961) and maintain both fossil species independently. The epidermal structure obtained from one fragmentary specimen corresponds exactly to the structure described for A. angustilobum from Seifhennersdorf (Walther and Kvaček 2007, p. 117). We follow this treatment stressing that foliage from the České středohoří Moutains assigned to A. angustilobum is difficult to discriminate from some forms of $A$. palaeosaccharinum as described below, which differ in epidermal anatomy (Walther 1972).

Material studied: Leaf impressions, NM-G2877, NM-G2993, NM-G8607, NM-G11505a, b, EK 363-371.

\section{Acer palaeosaccharinum STUR}

\section{Pl. 18, Fig. 6-7}

1867

Acer palaeosaccharinum STUR, p. 177, pl. 5, fig. 8 .

1961 Acer palaeosaccharinum STUR; Knobloch, p. 284, pl. 1, fig. 11, pl. 9, fig. 3, 5-8, 10, pl. 9, fig. 6-7.

Knobloch (1958) described leaf forms which he assigned to Acer palaeosaccharinum STUR as follows (translation from Czech): "Leaves 3-5 lobed, base rounded to subcordate, margin widely simple to double dentate with teeth of different size. Venation palmate, basal veins at $40-50^{\circ}$, secondary veins craspedodromous, only slightly bent, tertiary veins forming polygonal fields." The blades are 16 to $76 \mathrm{~mm}$ long and 18 to $85 \mathrm{~mm}$ wide. The epidermal structure was not preserved.

D i s c u s s i o n. This species prevails in the Knížecí leaf assemblage. As noted above, aberrant leaf forms of Acer palaeosaccharinum can be misinterpreted as A. angustilobum.

Material studied: Leaf impressions, NM-G2814, NM-G2872， NM-G2874， NM-G2875， NM-G2876, NM-G2879，NM-G2880，NM-G2900，NM-G8605，EK several impressions not numbered. 


\section{Acer integrilobum WEBER}

$$
\text { P1. 18, Fig. } 4
$$

Acer integrilobum C.O. WeBER, p. 196, pl. 22, fig. $5 \mathrm{a}-5 \mathrm{~b}$ (non fig. $5 \mathrm{c}$ ).

Leaf trilobate, ca. $20 \mathrm{~mm}$ long and fragmentary in width, lobes entire-margined.

D i s c u s s i on. Such maple leaves with almost entire margin are rare in the Oligocene leaf assemblages of the České středohoří Mountains (Walther 1972, Kvaček and Walther 1998). They occur commonly in the Oligocene localities Rott and Seifhennersdorf and differ from entire-margined trilobed forms of $A$. integerrimum (VIVIANI) MASSOLONGO in acuminate apices of lobes (Walther 1972).

Material studied: Leaf impression, EK 362.

\section{Acer sp.}

P1. 18, Fig. 5

1961

Acer sp.; Knobloch, p. 286, pl. 7, fig. 8, pl. 11, fig. 8 .

Isolated mericarps of winged double samaras, $22-45 \mathrm{~mm}$ long, 8-35 $\mathrm{mm}$ wide, seed part rounded, 5-7 $\mathrm{mm}$ in diameter, attachment scar at a very narrow angle to the fruit length.

D is cus s ion. Knobloch (1961) proposed that the fruits occurring at Knížecí belong to foliage of $A$. palaeosaccharinum which prevails in the Knížecí plant assemblage. Such fruits have been described as Acer cyclospermum GÖPPERT from the upper Oligocene deposits in the Rhineland (Winterscheid and Kvaček 2014). The connection between fossil maple fruits and foliage has not so far been firmly resolved.

Material studied: Detached maple mericarps, NM-G2860, NM-G2992, NM-G8596, EK 372-373.

\section{Malvaceae Jussieu}

\section{Craigia W.W. SMITH et W.E. Evans Craigia bronnii (UNGER) KVAČEK, BŮŽEK et Manchester}

\section{Pl. 19, Fig. 1-2}

1845 Ulmus bronnii UnGer, p. 79, pro parte, pl. 25, fig. 2-4 (non fig. 1).

1948 Pteleaecarpum bronnii (UNGER) Weyland, p. 130, pl. 21, fig. 5, text-fig. 5-9.

1961 Pteleaecarpum bronnii (Unger) WeYland; Knobloch, p. 280, pl. 6, fig. 11, pl. 13, fig. 12.

1991 Craigia bronnii (UNGER) KVAČEK, BU゚ŽEK et MANCHESTER, p. 522.

Winged broadly oval to rounded fruit valves $10-12 \mathrm{~mm}$ wide and 12-17 mm long with spindle-shaped medial locule, rarely with a small ovate seed inside. Venation of the wing composed of narrow elongated fields radiating from the locule, steeper in the upper part.
D i s c u s s i o n. These fruit remains agree in size and morphology with other records of the same species, commonly recovered from the Oligocene and Miocene of Central Europe (Kvaček et al. 2005).

Material studied: Detached fruit valves, EK 374-376.

\section{Cornaceae Berchtold et J. PresL}

\section{Cornus Linnaeus \\ Cornus studeri HeER}

\author{
Pl. 19, Fig. 4
}

1859 Cornus studeri HeER, p. 27, pl. 105, fig. 18-21.

1861 Rhamnus graeffii HeER; Heer, p. 287, pl. 10, fig. 13. 1961 Cornus studeri HeER; Knobloch, p. 288, pl. 13, fig. $1-3,11$.

Leaves rounded elliptical, blade $31-74 \mathrm{~mm}$ long, 17-50 mm wide, entire-margined, secondary veins very steep, directed subparallel towards the apex. Tertiary venation not preserved.

D i s c u s s i o n. The exact affinity of this morpho-type is equivocal (see discussion in Knobloch 1961, p. 288) and is not supported by any epidermal study.

Material st ud i ed : Leaf impressions, NM-G2999, NM-G8598, NM-G8606, NM-G2883a, b, EK 378-380.

\section{Hydrangeaceae DUMORTIER \\ Hydrangea LINNAEUS \\ Hydrangea microcalyx SIEBER}

$$
\text { P1. 19, Fig. } 3
$$

1880 Hydrangea microcalyx SIEBER, p. 16, pro parte, fig. 26-27, 31.

1961 Paliurus thurmannii HeER; Knobloch, p. 287, pl. 11, fig. 11.

Petaloid sepal entire-margined, described by Knobloch (1958, as Paliurus thurmannii translated from Czech) as follows: "The main vein is straight and accompanied on both sides by bent basal veins running towards the apex. The outer side of the basal veins is bordered by small loops. The inner area between main veins shows irregularly disposed areoles". The only specimen available is $18 \mathrm{~mm}$ long and $13 \mathrm{~mm}$ wide,

D i s c u s s i o n. The single petaloid sepal recovered at Knížecí was erroneously assumed by Knobloch (1961) to represent a leaf impression. Similar, more complete remains of Hydrangea microcalyx are also known from Kučlín (Kvaček and Teodoridis 2011), Suletice-Berand (Kvaček and Walther 1995) and Seifhennersdorf (Walther and Kvaček 2007).

Material studied: One sepal impression, NM-G8585. 


\section{Oleaceae HoffMAnn et LINK}

\section{Oleinites CoOKson Oleinites hallbaueri (MAI) SACHSE}

\author{
Pl. 6, Fig. 8, P1. 19, Fig. 5-7
}

1885 Carya elaenoides UNGER; Engelhardt, p. 67, pl. 25, fig. 1-4.

1961 Myrica lignitum (UNGER) SAPORTA; Knobloch, p. 256, pro parte, pl. 3, fig. 1-2.

1961 cf. Ilex rottensis WeYLAND; Knobloch, p. 282, pl. 13, fig. 10.

1963 Myrica hallbaueri MAI, p. 46, pl. 2, fig. 4-6, text-fig. 3a.

2001 Oleinites hallbaueri (MAI) SACHSE, p. 319, pl. 2, fig. 8-9.

Leaves elongate, up to $142 \mathrm{~mm}$ long and $65 \mathrm{~mm}$ wide, widely coarsely dentate, acuminate at the apex, rounded at the base, venation semicraspedodromous, midrib straight. Secondary veins regularly spaced, at wide angles, at the ends abruptly looping, and sending side veinlet into the teeth. Simple intersecondaries occasionally present, tertiary venation very fine, forming irregular fields. The cuticle structure poorly preserved, showing straight-walled cells on the adaxial epidermis and peltate trichomes with unicellular base, which is reflected in the outline as a double line.

Discussion. Knobloch (1961) merged this morpho-type with Myrica lignitum but stressed the heterogeneity of this species in his concept. Mai (1963) separated it as a new species of Myrica. Later studies of the epidermal anatomy (Sachse 2001) confirmed the affinity to the Oleaceae and not to the Myricaceae. Our structure of the peltate trichomes from specimen NM-G2812 matches the pattern found on the holotype (Bůžek et al. 1976).

Material studied: Leaf impressions, NM-G2812, NM-G2828, NM-G2832, NM-G4859a, b, NM-G8602, EK 381-382, more specimens not numbered.

\section{Dicotyledonae inc. fam.}

\section{Saportaspermum MeYer et MANCHESTER} Saportaspermum cf. occidentale MEYER et MANCHESTER

\section{Pl. 20, Fig. 9}

Winged seeds $10 \mathrm{~mm}$ long and $4 \mathrm{~mm}$ wide matching previous records from the Oligocene and Miocene of North America (Meyer and Manchester 1997) and Central Europe (see Walther and Kvaček 2007).

Discussion. The affinity of these winged seeds described above has not yet been resolved, although such remains regularly accompany similar leaf assemblages of Oligocene and Miocene age. As they have been dispersed by wind and occur sporadically, their parent plants may belong to elements growing far from the nearby vegetation.

Material studied: NM-G11483, EK 394.

\section{Dicotylophyllum SAPORTA \\ Dicotylophyllum cf. heeri (ENGELHARDT) \\ KVAČEK et WALTHER \\ P1. 20, Fig. 5}

cf. 1998 Dicotylophyllum heerii (ENGELHARDT) KVAČEK et WALTHER, p. 14, pl. 6, fig. 5-6, text-fig. 7-8, 13.28 .

Fragments of (?) ovate leaves, rounded at base, long petiolate, with two glands next the leaf base, margin glandular serrate-crenate. Venation semicraspedodromous, midrib stout, secondary veins bent along the margin, at wider angles. Poorly preserved cuticle reflects only oval openings of stomata. Cuticle of the midrib is hairless and consists of isodiametric polygonal straight-walled cells.

D i s c u s s i o n. The affinity to Prunus is suggested by the presence of glands on the leaf base.

Material studied: Leaf fragments, NM-G11488a, b, NM-G11512.

\section{Dicotylophyllum sp. 1}

P1. 20, Fig. 1

1961 Juglans acuminata A. BRAUN; Knobloch, p. 258, pl. 4, fig. 2.

1961 Ficus arcinervia (ROSSMÄSSLER) HEER; Knobloch, p. 273, pl. 7, fig. 5-6.

1961 cf. Rhus pteleaefolia WEBER; Knobloch, p. 286, pl. 8 , fig. 1 .

Leaflets (?) elongate oval, entire-margined, 45-81 mm long, 23-30 mm wide. Midrib straight, thick, secondary veins looping well within the margin. Tertiary veins almost perpendicular to the secondaries, forming loops along the margin. One specimen has a long tip.

D i s c u s s i o n. This entire-margined morpho-type has been assigned to various genera (e.g. Cedrela by Palamarev and Petkova 1987) but so far no definite solution has been reached. The foliage is chartaceous, not suitable for cuticle studies.

Mate rial studied: Leaf impressions, NM-G2834, NM-G2857, NM-G2864.

\section{Dicotylophyllum sp. 2}

\section{Pl. 20, Fig. 2-3}

1961

1998

Leguminosites sp.; Knobloch, p. 280, pl. 14, fig. 6. "Palaeolobium"sp. 1; Kvaček and Walther, p. 23, pl. 13, fig. 1-2, text-fig. 13.24.

Leaves long petiolate, entire-margined with narrow elliptical to elongate blade, $19 \mathrm{~mm}$ long, $9 \mathrm{~mm}$ wide, rounded at apex, cuneate at base.

$\mathrm{D}$ is c u s s i o n. The affinity of these leaf forms is quite uncertain (Kvaček and Walther 1998); Knobloch (1961) believed that such morpho-types may represent foliage of legumes. Contrary to most legume leaflets, the discussed leaf remains are long petiolate and in our opinion may more likely represent simple leaves. 
Material studied: Leaf impressions, NM-G8597a, b, EK 383-386.

\section{Dicotylophyllum sp. 3}

Pl. 20, Fig. 4

1961

Juglans (Carya) bilinica Unger; Knobloch, p. 258, pro parte, pl. 4, fig. 9.

Along with specimens identified as Juglans (Carya) bilinica and included here to Cyclocarya (see above) one broader leaf fragment ca. $45 \mathrm{~mm}$ wide assigned by Knobloch (1961) to Juglans deviates in its forked secondaries.

$\mathrm{D}$ i s c u s s i o n. This fragmentary specimen may indeed represent a large leaflet, but a better interpretation would be as Fraxinus rather than Juglans.

Material studied: Leaf impression, NM-G2837.

\section{Dicotylophyllum sp. 4}

Pl. 20, Fig. 8

1961 Sibirea rottensis WEYLAND; Knobloch, p. 278, pl. 8, fig. 12 .

Leaf elongate, entire-margined, in the preserved specimen a length of $50 \mathrm{~mm}, 11 \mathrm{~mm}$ wide, apex bluntly rounded. Venation brochidodromous, irregular, midrib straight, secondary veins very steep, almost parallel with the midrib, forming elongated fields. Tertiary venation very fine, reticulate (according to Knobloch 1958, 1961, emended).

D i s c u s s i o n. Knobloch (1961) compared the single fragment described above with foliage of Sibirea rottensis WeYLAND, 1941 from the upper Oligocene of Rott. This interpretation has not been confirmed so far.

Material studied: Leaf impression, NM-G2889.

\section{Dicotylophyllum sp. 5}

Pl. 20, Fig. 7

1961 Aesculus cf. palaeocastanum EtTingShausen; Knobloch, p. 283, pl. 1, fig. 6, pl. 8, fig. 12.

Leaflets (?) elongate, shortly petiolulate, blades incomplete, more than $36 \mathrm{~mm}$ long, $31 \mathrm{~mm}$ wide, margin double serrate, midrib bent, quite thick. Secondary veins at narrow angles, craspedodromous. Tertiary veins perpendicular or oblique between secondary veins.

D i s c u s s i o n. Knobloch (1961) interpreted one leaf impression (NM-G2866) as a leaflet belonging to Aesculus and another fragment (NM-G8594) as a slightly different form of the same species (Knobloch 1958). In our opinion the affinity of both these impressions is very doubtful.

Material studied: Leaf impressions, NM-G2866, NM-G8594.

\section{Dicotylophyllum sp. 6}

Pl. 20, Fig. 5

Celastrus persei UnGER; Knobloch, p. 281, pl. 8, fig. 6 .
Leaf oval, $23 \mathrm{~mm}$ long, $17 \mathrm{~mm}$ wide, widely cuneate at base, apex bluntly acute, margin crenulate, venation semi-craspedodromous, secondary veins at wide angles, bent along the margin, sending out veinlets which end between the teeth.

D i s c u s s i o n. Knobloch (1961) believed according to the architecture and venation of this single impression that it certainly belonged to Celastrus. Perhaps more reasons should be put forward for such a determination, although the morpho-type is quite distinct and noteworthy.

Material studied: Leaf impression, NM-G2862.

\section{Carpolithes STERnBerg Carpolithes sp. 1}

P1. 20, Fig. 11

1961? Pisonia eocenica EtTINGSHAUSEn; Knobloch, p. 289 , pl. 1 , fig. 10

A minute narrow elliptical object with a long bent stalk or style.

D is cussion. This fossil described from Knížecí resembles a separated fruitlet of Platanus neptuni but no additional material is available to support a more precise identification.

Material studied: ? fruitlet impression, NM-G2813 a, b.

\section{Carpolithes sp. 2}

P1. 20, Fig. 10

1961 Carpolithes sp.; Knobloch, p. 289, pl. 8, fig. 11

Flattened rounded unidentifiable seeds (or fruits) ca. $2.5 \mathrm{~mm}$ in diameter, partly on a short stout stalk.

D is c us sion. The objects are poorly preserved and require a more detailed comparative study.

Material studied: Compressed seeds or fruits, NM-G2870, EK 396-398.

\section{Excluded objects inc. sed.}

1961

Betula sp.; Knobloch, p. 267, pro parte, pl. 10, fig. 6.

The fossil originally interpreted as a birch catkin did not yield any pollen. On detailed examination it seemed to be composed of fragments of fish scales and may represent a coprolite.

Material studied: One enigmatic fossil, NM-G2886a.

\section{Comparison with other palaeobotanical sites in north Bohemia and adjacent Saxony}

The Knížecí plant assemblage is from a recently examined site and the available collection is not so extentsive in comparison with historical localities, such as e.g. 
Kundratice, Suletice and Kučlín in the České středohoří Mountains and Seifhennersdorf in Saxony. The flora falls undoubtedly into the Kundratice-Seifhennersdorf floral assemblage, as defined by Kvaček and Walther (1998, for a more detailed comparison see Walther and Kvaček 2007, p. 132-4). The flora with the closest relationship to the Knížecí flora appears to be the Seihennersdorf assemblage; this is also supported by the geographic and chronostratigraphic proximity. Several, new and only partly proven elements stress common features of both sites, namely the combination of conifers (Taxodium, Tetraclinis, Torreya) and angiosperms (Platanus neptuni, Daphnogene, Toxicodendron, the same species of Ulmus, Carpinus, Betula, Juglandaceae, Acer, Rosa, Ampelopsis etc.). There are only a few noteworthy differences. The occurence of Taxus engelhardtii in Knížecí is shared with Kundratice, Liriodendron haueri and Pinus cf. rigios with Žichov and Comptonia with Suletice. The restricted spectrum of the Lauraceae and other termophilous elements (e.g. Sloanea) is similar to that of Bechlejovice. Although the dating of Knížecí is not exact, the prevailing deciduous character of the angiosperms suggests that Knížecí can be assumed as being from the early stages of Oligocene floras in North Bohemia (Bechlejovice, Kundratice) and it shows similarities with the flora of Roudníky (Kvaček et al. 2014) dated into the latest Eocene. Significant differences can be found between Knížecí and Kučlín (Kvaček and Teodoridis 2011), the latter lacking most of the deciduous angiosperms noted above. This Eocene flora, together with some others from North Bohemia with Doliostrobus (drill cores Hlinná and Lbín), deserves more detailed analysis in the future based on evidence of angiosperms from sites adjacent to Kučlín. These floras may represent a new plant complex contemporaneous with that of Hordle-Zeitz sensu Mai (1995). Younger Oligocene sites (Markvartice, Flörsheim) indicate warming trends reflected in the higher diversity of termophilous elements, namely the Lauraceae. The Knížecí flora is in this respect quite poor, containing only Daphnogene and Laurophyllum medimontanum.

\section{Implications on vegetation and palaeoclimatology}

The IPR analysis of the plant assemblage of Knížecí produces the following scores for the key components, i.e. broad-leaved deciduous (BLD) - $78.7 \%$, broad-leaved evergreen (BLE) - $17.8 \%$, sclerophyllous + legume-like (SCL+LEG) $-3.6 \%$ and zonal herbaceous (ZONAL HERB) $-2.1 \%$. This indicates a transitional zonal vegetation type between Mixed Mesophytic Forest and Broad-leaved Deciduous Forest sensu Teodoridis et al. (2011). The species diversity is not very high and some morphotypes included in the analysis may contain more natural species (e.g. Laurophyllum sp.), some others are not preserved well enough for accurate evaluation. However this ecotonal type of zonal vegetation was also estimated for the other early Oligocene plant assemblages of Kundratice (Kvaček and Walther 1998), Hammerunterwiesenthal (Walther 1998), Seifhennersdorf (Walther and Kvaček 2007), Suletice-Berand (Kvaček and Walther 1995) and Markvartice-Veselíčko
(Bůžek et al. 1976) - for detail see Teodoridis and Kvaček (2015).

The studied material is in some cases fragmentary and not really suitable for statistical physiognomical studies, such as CLAMP and any results must be taken cautiously. The CLAMP results (using the 144 site calibration dataset) estimate the climatic character of Hrazený to be as follows: mean annual temperature (MAT) $-11.3{ }^{\circ} \mathrm{C}$, warmest month mean temperature (WMMT) $-22.1^{\circ} \mathrm{C}$, coldest month mean temperature $(\mathrm{CMMT})-1.7{ }^{\circ} \mathrm{C}$, precipitation during 3 consecutive wettest months (3-WET) - $1357 \mathrm{~mm}$ and precipitation during 3 consecutive driest months (3-DRY) $254 \mathrm{~mm}$. The MAT proxy derived from Leaf Margin Analysis sensu $\mathrm{Su}$ et al. (2010) shows a result comparable with CLAMP, i.e., $11.2{ }^{\circ} \mathrm{C}$ (Sampling Error is $2.5^{\circ} \mathrm{C}$ ). We are indebted to Torsten Utescher, who kindly provided parallel proxy data based on the Coexistence Approach (CA) for the following characters: MAT $\left(14.6-18.9^{\circ} \mathrm{C}\right)$ WMMT $\left(24.7-28.3^{\circ} \mathrm{C}\right)$, CMMT $\left(5-12.2^{\circ} \mathrm{C}\right)$ and mean annual precipitation - MAP (979-1213 $\mathrm{mm})$. The CA estimates produces higher values than those from physiognomic techniques. In general, the proxy-data from Knížecí fit well into the palaeoclimatic evolution of the Bohemian Massif during the Palaeogene, as formulated by Teodoridis and Kvaček (in press), corresponding to a slight warming trend after the late Eocene/early Oligocene climatic collapse.

\section{Acknowledgements}

We are grateful to the curators of the collections of the Czech Geological Survey in Prague who allowed us to use the undescribed material collected by Erwin Knobloch for the present study. We are also indebted to Jiří Kvaček who made accessible the collections of the National Museum in Prague and also technically supported this study by making the microscopic technique available. Greatly appreciated are also the suggestions and notes made by two reviewers on the first version of the manuscript. We acknowledge consultations with Tomáš Přikryl (Prague) on the fish fauna. The study was financially supported by the grant project GAČR No. 14-23108S.

\section{References}

Akhmetiev, M., Walther, H., Kvaček, Z. (2009): Mid-latitude Palaeogene floras of Eurasia bound to volcanic setting and palaeoclimatic events - experience obtained from the Far East Russia (Sikhote-Alin') and Central Europe (Bohemian Massif). - Acta Musei nationalis Pragae, Series B - historia naturalis, 65(3-4): 61-121.

Andrews, H. N. jun. (1955): Index of generic names of fossil plants, 1820-1950. - Bulletin of the US Geological Survey, 1013: 1-262.

Andrews, H. N. jun. (1970): Index of generic names of fossil plants, 1820-1965. - Bulletin of the US Geological Survey, 1300: 1-354.

Archenegg, A. N. v. (1894): Über atavistische Blattformen des Tulipenbaumes. - Denkschriften der kaiserlichen Akademie der Wissenschaften, mathematisch-naturwissenschaftliche Klasse, 61: 269-284. 
Bellon, H., Bůžek, Č., Gaudant J., Kvaček, Z., Walther, H. (1998): The České Středohoří magmatic complex in Northern Bohemia. 40K_40Ar ages for volcanism and biostratigraphy of the Cenozoic freshwater formations. Newsletters on Stratigraphy, 36(2-3): 77-103.

Böhme, M. (2007): Revision of the cyprinids from the Early Oligocene of the České Středohoří Mountains, and the phylogenetic relationships of Protothymallus Laube 1901 (Teleostei, Cyprinidae, Gobioninae). - Acta Musei nationalis Pragae, Series B - historia naturalis, 63: 175-194.

Bowerbank, J. S. (1840): A history of the fossil fruits and seeds of the London Clay. - John Van Voorst, London, 144 pp.

Brongniart, A. (1822): Sur la classification et la distribution des végétaux fossiles ein general, et sur ceux des terrains de sediment supérieur en particulier. - Mémoires du Muséum National d'histoire naturelle, 8: 203-248.

Brongniart, A. (1828): Notice sur les plantes d'Armissan près Narbonne. - Annales des sciences naturelles, botanique, série 1, 15: 43-51.

Brown, R. W. (1935): Miocene leaves, fruits, and seeds from Idaho, Oregon, and Washington. - Journal of Paleontology, 9(7): 572-587.

Bůžek, Č., Holý, F., Kvaček, Z. (1967): Eine bemerkenswerte Art der Familie Platanaceae Lindl. (1836) im nordböhmischen Tertiär. - Monatsberichte der Deutschen Akademie der Wissenschaften zu Berlin, 9: 203-215.

Bůžek, Č., Holý, F., Kvaček, Z. (1976): Tertiary flora from the Volcanogenic Series at Markvartice and Veselíčko near Česká Kamenice (České Středohoří Mts.). - Sborník Ústředního ústavu geologického, Paleontologie, 18: 69-132.

Bůžek, Č., Kvaček, Z., Walther, H. (1981): Blattreste von Vitaceen aus dem Oligozän Mitteleuropas. Palaeontographica, Abteilung B, 175: 126-155.

Christenhusz M. J. M., Reveal J. L., Farjon A., Gardner M. F., Mill R. R., Chase M. W. (2011): A new classification and linear sequence of extant gymnosperms. - Phytotaxa, 19: $55-70$.

Engelhardt, H. (1870): Flora der Braunkohlenformation im Königreich Sachsen. - Preisschrift der Fürstlichen Jablonowski'schen Gesellschaft, Leipzig, 16: 1-69.

Engelhardt, H. (1885): Die Tertiärflora des Jesuitengrabens bei Kundratitz in Nordböhmen. - Nova Acta Academiae Leopoldinae, 48: 275-324.

Ettingshausen, C. (1853): Die Tertiäre Flora von Häring in Tirol. - Abhandlungen der Kaiserlich-Königlichen Geologischen Reichsanstalt, 2(2): 1-118.

Ettingshausen, C. v. (1866): Die fossile Flora des Tertiärbeckens von Bilin, I. - Separatum from Denkschriften der kaiserlichen Akademie der Wissenschaften, mathematisch-naturwissenschaftliche Klasse, 26: 1-98.

Ettingshausen, C. v. (1869): Die fossile Flora des Tertiärbeckens von Bilin, III. - Denkschriften der kaiserlichen Akademie der Wissenschaften, mathematisch-naturwissenschaftliche Klasse, 29: 1-110.

Florin, R. (1948): On the morphology and relationships of the Taxaceae. - Botanical Gazette, 110(1): 31-39. http://dx.doi.org/10.1086/335515
Florin, R. (1958): On Jurassic taxads and conifers from northwestern Europe and eastern Greenland. - Acta Horti Bergiani, 17(10): 257-402.

Göppert, H. R. (1838): De floribus in statu fossili commentatio. - Verhandlungen der Kaiserlichen Leopoldinisch-Carolinischen Deutschen Akademie der Naturforscher, 18: 547-572.

Hably, L., Erdei, B., Kvaček, Z. (2001): 19th century's palaeobotanical types and originlas of the Hungarian Natural History Museum. - Hungarian Natural History Museum, Budapest, 235 pp.

Heer, O. (1855): Flora Tertiaria Helvetiae, I. - J. Wurster et comp., Winterthur, $117 \mathrm{pp}$.

Heer, O. (1856): Flora Tertiaria Helvetiae, II. - J. Wurster et comp., Winterthur, $110 \mathrm{pp}$.

Heer, O. (1859): Flora Tertiaria Helvetiae, III. - J. Wurster et comp., Winterthur, $378 \mathrm{pp}$.

Heer, O. (1861): Beiträge zur näheren Kenntnis der Sächsisch-thüringischen Braunkohlenflora. - Abhandlungen des Naturwissenschaftlichen Vereins für Sachsen und Thüringen in Halle, 2: 405-438.

Heer, O. (1869): Miocene baltische Flora. - Beiträge zur Naturkunde Preussens, 2: 1-104.

Herendeen, P. S., Dilcher. D. L. (1990): Fossil mimosoid legumes from the Eocene and Oligocene of southeastern North America. - Review of Palaeobotany and Palynology, 62: 339-361. http://dx.doi.org/10.1016/0034-6667(90)90094-Y

Herrmann, O., Beck, R. (1897): Erläuterungen zur geologischen Karte des Königsreich Sachsen. Sektion Hinterhermsdorf-Daubitz. - W. Engelmann, Leipzig, 53 pp.

Il'inskaya, I. A. (1953): Monografiya roda Pterocarya Kunth [Monography of the genus Pterocarya Kunth.]. - Trudy Botanicheskogo Instituta imeni V. L. Komarova AN SSSR, Series 1, 10: 7-123. (in Russian)

Jähnichen, H., Mai, D. H., Walther, H. (1977): Blätter und Früchte von Engelhardia Lesch. ex Bl. (Juglandaceae) aus dem europäischen Tertiär. - Feddes Repertorium, 88: 323-363.

http://dx.doi.org/10.1002/fedr.19770880503

Jeremies, M. (2006): Bemerkenswerte tertiäre Blattfossilien aus den Schlukenauer Hügeland bei Hainspach (Lipová). - Berichte der Naturforschenden Gesellschaft Oberlausitz, 14: 17.

Knobloch, E. (1958): Terciérní flora Pirskenbergu u Šluknova a její vztah k okolním oblastem [Tertiary flora of Pirskenberg near Šluknov and its relationship to adjacent regions]; Diplomová práce [Diploma thesis]. MS, Univerzita Karlova, Př́rodo-vědecká fakulta [Charles University, Faculty of Sciences], Prague, Czech Republic, 114 pp. (in Czech) (Geological Library, Faculty of Sciences, Charles University)

Knobloch, E. (1961): Die oberoligozäne Flora des Pirskenberges bei Šluknov in Nord-Böhmen. - Sborník Ústředního ústavu geologického, Paleontologie, 26: 241-315.

Knobloch, E. (1998): Der pliozäne Laubwald von Willershausen am Harz (Mitteleuropa). - Documenta Naturae, 120: 1-302.

Knobloch, E., Kvaček, Z. (1976): Miozäne Blätterfloren vom Westrand der Böhmischen Masse. - Rozpravy Ústředního ústavu geologického, 42: 1-131. 
Köhler, J., Uhl, D. (2014): Die Blatt- und Karpoflora der oberoligozänen Lagerstätte Enspel (Westerwald, Rhinland-Pfalz, W-Deutschland). - Mainzer Naturwissenschaftliches Archiv, Beihefte, 35: 1-87.

Kotlaba, F. (1963): Tertiary plants from three new localities in Southern Slovakia. - Sborník Národního muzea, řada B, 19(2): 53-72.

Kovar-Eder, J., Kvaček, Z., Ströbitzer-Hermann, M. (2004): The Miocene Flora of Parschlug (Styria, Austria) Revision and Synthesis. - Annalen des Naturhistorischen Museums, Wien, 105A: 45-159.

Kunzmann L., Kvaček Z., Mai D. H., Walther H. (2009): The genus Taxodium (Cupressaceae) in the Palaeogene and Neogene of Central Europe. - Review of Palaeobotany and Palynology, 153: 153-183.

http://dx.doi.org/10.1016/j.revpalbo.2008.08.003

Kustatscher, E., Roghi, G., Bertini, A., Miola, A. (eds) (2014): La storia delle plante fossili in Italia [Palaeobotany of Italy]. - Museo di Scienze Naturali dell'Alto Adige, Bolzano, 395 pp. (in Italian)

Kvaček, Z. (1971): Fossil Lauraceae in the stratigraphy on the North Bohemian Tertiary. - Sborník Ústředního ústavu geologického, Paleontologie, 13: 47-86.

Kvaček, Z. (1976): Towards nomenclatural stability of European Tertiary Conifers. - Neues Jahrbuch für Geologie und Paläontologie, Monatshefte, 1975(5): 284-300.

Kvaček, Z. (1984): Tertiary taxads of NW Bohemia. - Acta Universitatis Carolinae, Geologica, 4(1982): 471-491.

Kvaček, Z. (1989): Fosilní Tetraclinis Mast. (Cupressaceae). - Časopis Národního muzea, řada př́rodovědná, 155: 45-54. (in Czech)

Kvaček, Z. (2004): Revisions to the Early Oligocene flora of Flörsheim (Mainz Basin, Germany) based on epidermal anatomy. - Senckenbergiana Lethaea, 84: 1-73. http://dx.doi.org/10.1007/BF03043465

Kvaček, Z. (2007): Do extant nearest relatives of thermophile European Tertiary elements reliably reflect climatic signal? - Palaeogeography, Palaeoclimatology, Palaeoecology, 253: 32-40. http://dx.doi.org/10.1016/j.palaeo.2007.03.032

Kvaček, Z., Knobloch, E. (1967): Zur Nomenklatur der Gattung Daphnogene UNGER und die neue Art Daphnogene pannonica sp. n. - Věstník Ústředního ústavu geologického, 42: 201-210.

Kvaček Z., Manchester, S. R. (2004): Vegetative and reproductive structure of the extinct Platanus neptuni from the Tertiary of Europe and relationships within the Platanaceae. - Plant Systematics and Evolution, 244: $1-29$.

http://dx.doi.org/10.1007/s00606-003-0082-2

Kvaček, Z., Teodoridis, V. (2011): A Late Eocene flora of Kučlín near Bílina in North Bohemia revisited. - Acta Musei nationalis Pragae, Series B - historia naturalis, 67(3-4): 77-82.

Kvaček, Z., Bůžek, Č., Manchester, S. R. (1991): Fossil fruits of Pteleaecarpum Weyland - Tiliaceous, not Sapindaceous. - Botanical Gazette, 152: 522-523. http://dx.doi.org/10.1086/337915

Kvaček, Z., Manchester, S. R., Schorn, H. E. (2000): Cones, seeds, and foliage of Tetraclinis salicornioides
(Cupressaceae) from the Oligocene and Miocene of western North America: a geographic extension of the European Tertiary species. - International Journal of Plant Sciences, 161(2): 331-344.

http://dx.doi.org/10.1086/314245

Kvaček, Z., Teodoridis, V., Gregor, H.-J. (2008): The Pliocene leaf flora of Auenheim, Northern Alsace (France). - Documenta naturae, 155(10): 1-108.

Kvaček, Z., Teodoridis, V., Mach, K., Přikryl, T., Dvořák, Z. (2014): Tracing Eocene-Oligocene transition: a case study from North Bohemia. - Bulletin of Geosciences, 89(1): 21-66.

Kvaček, Z., Walther, H. (1995): The Oligocene volcanic flora of Suletice-Berand near Ústí nad Labem, North Bohemia - a review. - Acta Musei nationalis Pragae, Series B historia naturalis, 50: 25-54.

Kvaček, Z., Walther, H. (1998): The Oligocene volcanic flora of Kundratice near Litoměřice, České středohoří Volcanic complex (Czech Republic). - Acta Musei nationalis Pragae, Series B - historia naturalis, 54: 1-43.

Kvaček, Z., Walther, H. (2004): Oligocene flora of Bechlejovice at Děčín from the neovolcanic area of the České Středohoří Mountains, Czech Republic. - Acta Musei nationalis Pragae, Series B - historia naturalis, 60: 9-60.

Li, Jianhua, Davis, C. C., Donogh, M. J., Kelley, S., Del Tredici, P. (2001): Phylogenetic relationship of Torreya (Taxaceae) inferred from sequence of nuclear ribosomal DNA ITS region. - Harvard Papers in Botany, 6(1): 275-281.

MacGinitie, H. D. (1953): Fossil plants of the Florissant beds, Colorado. - Publications of the Carnegie Institution, Washington, 599: 1-198.

Mai, D. H. (1963): Beiträge zur Kenntnis der Tertiärflora von Seifhennersdorf (Sachsen). - Jahrbuch des Staatlichen Museums für Mineralogie und Geologie zu Dresden, 1963: 39-114.

Mai, D. H. (1995): Tertiäre Vegetationsgeschichte Europas. - Gustav Fischer Verlag, Jena, 691 pp.

Mai, D. H., Walther, H. (1978): Die Floren der Haselbacher Serie im Weisselster - Becken (Bezirk, Leipzig, DDR). - Abhandlungen des Museums für Mineralogie und Geologie zu Dresden, 28: 1-101.

Massalongo, A., Scarabelli, G. (1859): Studii sulla Flora Fossile e Geologia Stratigrafica del Senigalliese. Tipografia d'Igbnazio Galeati e figlio, Imola, 504 pp.

Meller, B. (2010): Type specimens in Ettingshausen's Tertiary flora from Häring in Tyrol (1853) in the collections of the Geological Survey of Austria. Jahrbuch der Geologischen Bundesanstalt, 150: 123-230.

Menzel, P. (1901): Die Gymnospermen der nordböhmischen Braunkohlenformation. - Abhandlungen der Naturwissenschaftlichen Gesellschaft Isis, 1900(2): 49-69, 85-110.

Meyer, H. W. (2013): The fossils of Florissant. - Smithsonian books, Washington and London, $258 \mathrm{pp}$.

Meyer, W., Manchester, S. R. (1997): The Oligocene Bridge Creek flora of the John Day Formation, Oregon.University of California Publications in Geological Sciences, 141: 1-195. 
Němejc, F., Kvaček, Z., Pacltová, B., Konzalová M. (2003): Tertiary plants of the Plzeň Basin (West Bohemia). Acta Universitatis Carolinae, Geologica, 46(4, 2002): 121-176.

Obrhelová, N. (1961): Vergleichende Osteologie der tertiären Süßwasserfische Böhmens (Gobioidei). Srovnávací osteologie třetihorních sledkovodních ryb (Gobioidei) v Čechách. - Sborník Ústředního ústavu geologického, Paleontologie, 26(1959): 103-192.

Palamarev, E. H., Petkova, A. S. (1987): La macroflore du Sarmatien. - In: Tzankov, V. (ed.), Les fossiles de Bulgarie VIII.1, Academie Bulgare des Sciences, Sofia, p. 1-275. (in Bulgarian with French summary)

Procházka, M. (1952): Javory severočeských třetihor [Maples of the Northbohemian Tertiary]; Rigorózní práce [RNDr. thesis]. - MS, Univerzita Karlova, Př́rodovědecká fakulta [Charles University, Faculty of Sciences], Prague, Czech Republic, 250 pp. (in Czech) (Geological Library, Faculty of Sciences, Charles University)

Procházka, M., Bůžek, Č. (1975): Maple leaves from the Tertiary of North Bohemia. - Rozpravy Ústředního ústavu geologického, 41: 1-86.

Přikryl, T. (2014): A new species of the sleeper goby (Gobioidei, Eleotridae) from the České Středohoří Mountains (Czech Republic, Oligocene) and analysis of the validity of the family Pirskeniidae. - Paläontologische Zeitschrift, 88: 187-188. http://dx.doi.org/10.1007/s12542-013-0188-y

Radoň, M., Kvaček, Z., Walther, H. (2006): Oligocene megafossil plant remains and environment from the newly recovered locality of the Holý Kluk hill near Proboštov (České středohoří Mountains, Czech Republic). - Acta Universitatis Carolinae, Geologica, 47: 95-124.

Reveal, J. L. (2012): An outline of a classification system for extant flowering plants. - Phytoneuron, 37: 1-221.

Sachse, M. (2001): Oleaceous laurophyllous leaf fossils and pollen from the European Tertiary. - Review of Palaeobotany and Palynology, 115: 213-234. http://dx.doi.org/10.1016/S0034-6667(01)00070-7

Saporta, G., Marion, A. F. (1876): Recherches sur les végétaux fossils de Meximieux. - Archives du Museum d'Histoire Naturelle de Paris, 1: 131-335.

Schlechtendal, D. H. R. (1897): Beiträge zur näheren Kenntnis der Braunkohlenflora Deutschlands. Abhandlungen der Naturforschenden Gesellschaft zu Halle, 21: 3-28.

Sieber, J. (1880): Zur Kenntnis der nordböhmischen Braunkohlenflora. - Sitzungeberichte der kaiserlichenköniglichen Akadamie der Wissenschaften, mathematischnaturwissenschaftliche Klasse, 82: 67-101.

Spjut, R. W. (2007): Taxonomy and nomenclature of Taxus (Taxaceae). - Journal of the Botanical Research Institute, Texas, 1(1): 203-289.

Sternberg, K. (1820-1838): Versuch einer botanischgeologischen Darstellung der Flora der Vorwelt. - F. Fleischer, Leipzig, Ernst Breck's Witwe, Regensburg, J. Spurny, G. Hässe Söhne, Prag, Bd.1, H.1:1-26 (1820), H. 2:1-33 (1822), H. 3:1-39 (1823), H. 4: 1-48, Tentamen, I-VIII (1825), Bd. 2, H. 5, 6: 1-80 (1833), H. 7, 8: 81-220 (1838).
Stur, D. (1867): Beiträge zur Kenntnis der Flora der Süßwasserquarzite, der Congerien- und Cerithienschichten im Wiener und ungarischen Becken. - Jahrbuch der Geologischen Reichsanstalt, 17(1): 77-188.

Su, T., Xing, Y. W., Liu, Y. S., Jacques, F. M. B., Chen, W. Y., Huang, Y. J., Zhou, Z. K. (2010): Leaf margin analysis: A new equation from humid to mesic forests in China. - Palaios, 25: 234-238.

http://dx.doi.org/10.2110/palo.2009.p09-129r

Teodoridis, V., Kovar-Eder, J., Mazouch, P. (2011): The IPR-vegetation analysis applied to modern vegetation in SE China and Japan. - Palaios, 26(10): 623-638. http://dx.doi.org/10.2110/palo.2010.p10-149r

Teodoridis, V., Kvaček, Z. (2015): Palaeoenvironmental evaluation of Cainozoic plant assemblages recovered from the Bohemian Massif (Czech Republic) and adjacent Germany. - Bulletin of Geosciences, 90(3): 695-720.

Unger, F. (1841-47): Chloris protogaea. 1-10. - W. Engelmann, Leipzig, 149 pp.

Unger, F. (1849): Die Pflanzenreste im Salzstocke von Wieliczka. - Denkschriften der kaiserlichen Akademie der Wissenschaften, mathematisch-naturwissenschaftliche Klasse, 1: 311-322.

Unger, F. (1850): Genera et species plantarum fossilium. W. Braunmüller, Vindobonae, XL +627 pp.

Unger, F. (1866): Sylloge plantarum fossilium III. Denkschriften der kaiserlichen Akademie der Wissenschaften, mathematisch-naturwissenschaftliche Klasse, 25: 1-79.

Walther, H. (1972): Studien über tertiäre Acer Mitteleuropas. - Abhandlungen des Staatlichen Museums der Mineralogie und Geologie zu Dresden, 19: 1-309.

Walther, H. (1998): Die Tertiärflora von Hammerunterwiesenthal (Freistaat Sachsen). - Abhandlungen des Staatlichen Museums der Mineralogie und Geologie zu Dresden, 43-44: 239-364.

Walther, H. (1999): Die Tertiärflora von Kleinsaubernitz bei Bautzen. - Palaeontographica, Abteilung B, 249: 61-174.

Walther, H., Kvaček, Z. (2007): Early Oligocene flora of Seifhennersdorf (Saxony). - Acta Musei nationalis Pragae, Series B - historia naturalis, 63(2-4): 85-174.

Weber, C.O. (1852): Die Tertiärflora der niederrheinischen Braunkohlenformation. - Palaeontographica, 2: 115-282.

Weise, A. (1890): Braunkohlenschichten in der Gegend von Schluckenau. - Mitteilungen des nordböhmischen Exkursions-Klubs, 15 (1): 15-19.

Weyland, H. (1941): Beiträge zur Kenntnis der Rheinischen Tertiärflora. V. Dritte Ergänzungen und Berichtigungen zur Flora der Blätterkohle und des Polierschiefers von Rott im Siebengebirge. - Palaeontographica, Abteilung B, 86 (4-6): 79-112.

Wessel, Ph., Weber, O. (1856): Neuer Beitrag zur TertiärFlora der niederrheinischen Braunkohlenformation. Palaeontographica, 4: 1-57.

Weyland, H. (1937): Beiträge zur Kenntnis der rheinischen Tertiärflora. II. Erste Ergänzungen und Berichtigungen zur Flora der Blätterkohle und des Polierschiefers von Rott im Siebengebirge. - Palaeontographica, Abteilung B, 83(1-3): 67-122.

Weyland, H. (1948): Beiträge zur Kenntnis der rheinischen Tertiärflora. VII. - Palaeontographica, Abteilung B, 88: 115-188. 
Winterscheid, H., Kvaček, Z. (2014): Revision der Flora aus den oberoligozänen Seeablagerungen von Orsberg bei Unkel am Rhein (Rheinland-Pfalz, Deutschland). Palaeontographica, Abteilung B, 291(1-3): 1-83.

\section{Explanation of the plates}

\section{PLATE 1}

\section{Muscites sp.}

1. Most complete specimen, NM-G11514 (scale bar $5 \mathrm{~mm}$ ).

2. Counter-impression to the missing Knobloch's original (1961, pl. 10, fig. 1). NM-G2888 (scale bar $3 \mathrm{~mm}$ ).

3. Magnified detail of the previous figure (scale bar $1 \mathrm{~mm}$ ).

\section{Pinus cf. rigios (UNGer) EtTINGSHAUSEN}

4. Fascicle of three needle leaves joined with sheat, EK 237a (scale bar $5 \mathrm{~mm}$ ).

5. Three fragmentary needle leaves, obviously from the same fascicle, EK 238 (scale bar $5 \mathrm{~mm}$ ).

\section{Taxodium dubium (STERnberg) HeER}

6. Most complete shoot with cuticle structure shown in P1. 2, Fig. 1, Knobloch's original (1961, pl. 2, fig. 8), NM-G2815a (scale bar $5 \mathrm{~mm}$ ).

7. Impression of another shoot, Knobloch's original (1961, pl. 10, fig. 2), NM-G2892 (scale bar $5 \mathrm{~mm}$ ).

\section{Tetraclinis salicornioides (UNGER) KVAČEK}

8. Fragment of a branched twig composed of wide medial segments with attached simple ultimate segments, EK 243 (scale bar $5 \mathrm{~mm}$ ).

9. Another branched twig fragment, EK 242 (scale bar $9 \mathrm{~mm})$.

10. Simple twig segment with cuticle isolated from the rock shown in Pl. 2, Fig. 2-3, NM-G11507 (scale bar 3 mm).

\section{Taxus engelhardtii KVAČEK}

11. Needle base with cuticle, NM-G11482a (scale bar $3 \mathrm{~mm}$ ).

12. Short needle with cuticle, NM-G11481a (scale bar $3 \mathrm{~mm}$ ).

13. Needle base with cuticle, NM-G11501a (scale bar $3 \mathrm{~mm}$ ).

\section{Torreya bilinica SAPORTA et MARION}

14. Needle fragment with cuticle (see arrow), NM-G11508a (scale bar $3 \mathrm{~mm}$ ).

15. Needle fragment with cuticle (see arrow), NM-G11510a (scale bar $1.5 \mathrm{~mm}$ ).

16. Complete needle compression with cuticle, NM-G11509a (scale bar $5 \mathrm{~mm}$ ).

\section{PLATE 2}

\section{Taxodium dubium (STERnberg) HeER}

1. Cuticle of the specimen shown in Pl. 1, Fig. 6 reflecting stomata, NM-G2815b (scale bar $100 \mu \mathrm{m}$ ).

\section{Tetraclinis salicornioides (UNGER) KVAČEK}

2. Cuticle of the specimen shown in Pl. 1, Fig. 10 reflecting stomatal zone, NM-G11507a (scale bar $100 \mu \mathrm{m}$ ).
3. Cuticle of the same specimen shown in Pl. 1, Fig. 10 reflecting non-stomatal zone, NM-G11507a (scale bar $100 \mu \mathrm{m})$.

\section{Taxus engelhardtii KvAČEK}

4. Cuticle of the specimen shown in Pl. 1, Fig. 13 reflecting medial non-stomatal zone, NM-G11501b (scale bar $100 \mu \mathrm{m}$ ).

5. Cuticle of the specimen shown in Pl. 1, Fig. 13 reflecting medial stomatal zone, NM-G11501b (scale bar $100 \mu \mathrm{m}$ ).

\section{Torreya bilinica SAPORTA et MARION}

6. Cuticle of the specimen NM-G11509a reflecting lateral non-stomatal zone showing papillae near stomatal band, NM-G11509b (scale bar $100 \mu \mathrm{m}$ ).

7. Stomatal band of the previous specimen, NM-G11509b (scale bar $100 \mu \mathrm{m}$ ).

8. Cuticle of the specimen shown in Pl. 1, Fig. 15 reflecting stomatal band devoid of distal parts of papillae, NM-G11510b (scale bar $100 \mu \mathrm{m}$ ).

\section{PLATE 3}

\section{Liriodendron haueri ETTINGSHAUSEN}

1. Long petiolate leaf base, Knobloch's original (1961, pl. 7, fig. 1), NM-G2859 (scale bar $10 \mathrm{~mm}$ ).

2. Shallowly lobed small leaf, Knobloch's original (1961, pl. 14, fig. 4, as Styrax sp.), NM-G8591 (scale bar $10 \mathrm{~mm}$ ).

3. Lobed leaf with cuticle shown in Pl. 6, Fig. 1, Knobloch's original (1961, pl. 7, fig. 3), NM-G2856a (scale bar $10 \mathrm{~mm})$.

4. Incomplete lobed leaf with well-preserved venation, NM-G2997 (scale bar $10 \mathrm{~mm}$ ).

\section{PLATE 4}

Laurophyllum medimontanum BŮžEK, HoLÝ et KVAČEK

1. Leaf compression with cuticle shown in Pl. 6, Fig. 2, NM-G3002a (scale bar $10 \mathrm{~mm}$ ).

2. Leaf impression, Knobloch's original (1961, pl. 8, fig. 9, as Salix longa A. BRAUN), NM-G2563a (scale bar $10 \mathrm{~mm}$ ).

\section{Laurophyllum sp.}

3. Leaf impression, Knobloch's original (1961, pl. 10, fig. 7, as cf. Laurus primigenia UNGER), NM-G2890a (scale bar $5 \mathrm{~mm})$.

4. Impression of a leaf fragment, EK 258 (scale bar $5 \mathrm{~mm}$ ).

5. Leaf compression with cuticle shown in P1. 6, Fig. 3, Knobloch's original (1961, pl. 10, fig. 4, as Laurus princeps HeER), NM-G2885a (scale bar $10 \mathrm{~mm}$ ).

6. Petiolate base of leaf impression, Knobloch's original (1961, not figured, as ? Benzoin attenuatum HeER), NM-G2977 (scale bar $10 \mathrm{~mm}$ ).

7. Impression of leaf fragment, Knobloch's original (1961, pl. 10, fig 8), NM-G2884 (scale bar $10 \mathrm{~mm}$ ).

\section{PLATE 5}

\section{Daphnogene cinnamomifolia (BRONGNIART) UNGER}

1. Leaf impression with cuticle, Knobloch's original (1961, pl. 1, fig. 7, as Cinnamomum scheuchzeri (HEER) FrENZEN), NM-G2811a (scale bar $5 \mathrm{~mm}$ ). 
2. Broad leaf fragment with cuticle, NM-G11497 (scale bar $5 \mathrm{~mm}$ ).

3. Small leaf compression with cuticle, NM-G11500a (scale bar $5 \mathrm{~mm}$ ).

4. Narrow leaf impression, EK 247(scale bar $5 \mathrm{~mm}$ ).

\section{“Typha” latissima A. BRAUN}

5. Leaf impression with preserved venation, EK 250 (scale bar $5 \mathrm{~mm}$ ).

6. Leaf impression with preserved venation, Knobloch's original (1961, pl. 12, fig. 7, as Typha latissima A. BRAUN), NM-G8593 (scale bar $5 \mathrm{~mm}$ ).

8. Narrow leaf impression longitudinally torn in two parts, EK 253 (scale bar $5 \mathrm{~mm}$ ).

\section{Poacites sp.}

7. Narrow leaf impression, EK 255 (scale bar $5 \mathrm{~mm}$ ).

\section{Smilax weberi WESSEL}

9. Impression of incomplete leaf base, Knobloch's original (1961, pl. 15, fig. 9, as Smilax grandifolia (UNGER) HEER), NM-G8081a (scale bar $5 \mathrm{~mm}$ ).

10. Impression of almost complete leaf, Knobloch's original (1961, pl. 13, fig. 7, as Smilax grandifolia (UNGER) HEER), NM-G8608 (scale bar $5 \mathrm{~mm}$ ).

\section{PLATE 6}

\section{Liriodendron haueri ETTINGSHAUSEN}

1. Smooth cuticle of lower leaf side reflecting outlines of stomata obtained from leaf impression published by Knobloch (1961, pl. 7, fig. 3), NM-G2856b (scale bar $50 \mu \mathrm{m})$.

\section{Laurophyllum medimontanum BŮŽEK, HoLÝ et KVAČEK}

2. Strongly papillate abaxial cuticle of lower leaf side of leaf compression shown in Pl. 4, Fig. 1, NM-G3704c (scale bar $50 \mu \mathrm{m})$.

\section{Laurophyllum sp.}

3. Thin cuticle with a trichome base from lower leaf side of leaf compression shown in Pl. 4, Fig. 5, NM-G2885b (scale bar $50 \mu \mathrm{m}$ ).

\section{Daphnogene cinnamomifolia (BRONGNIART) UNGER}

4. Hairy abaxial cuticle of leaf compression shown in Pl. 5, Fig. 1, NM-G2811b (scale bar $50 \mu \mathrm{m}$ ).

Platanus neptuni (ETTINGSHAUSEN) BŮŽEK, HolÝ et KVAČEK 5. Abaxial cuticle of the specimen shown in Pl. 7, Fig. 2. NM-G11504b (scale bar $50 \mu \mathrm{m}$ ).

\section{Comptonia difformis (STERNBERG) BERRY}

6. Abaxial cuticle with peltate trichomes from the specimen shown in Pl. 13, Fig. 3, NM-G11506b (scale bar $50 \mu \mathrm{m}$ ).

\section{Acer angustilobum HEER}

7. Papillate abaxial cuticle from the specimen shown in Pl. 18, Fig. 3, NM-G11505b (scale bar $50 \mu \mathrm{m}$ ).

\section{Oleinites hallbaueri (MAI) SACHSE}

8. Adaxial cuticle with peltate trichome from the specimen shown in P1. 19, Fig. 5, NM-G2812b (scale bar $50 \mu \mathrm{m}$ ).

Engelhardia orsbergensis (WESSEL et WEBER) JÄHNICHEN, Mai et Walther

9. Abaxial cuticle from the specimen shown in Pl. 14, Fig. 5, NM-G11511b (scale bar $50 \mu \mathrm{m}$ ).

\section{PLATE 7}

Platanus neptuni (ETTINGSHAUSEN) BŮžEK, HolÝ et KVAČEK 1. Leaf impression, Knobloch's original (1961, pl. 10, fig. 12, as Ceratopetalum bilinicum ETTINGSHAUSEN), NM-G2887 (scale bar $5 \mu \mathrm{m}$ ).

2. Leaf compression with cuticle, NM-G11504a (scale bar $5 \mathrm{~mm})$.

3. Leaf compression with cuticle, NM-G11503a (scale bar $10 \mathrm{~mm})$

4. Leaf compression with cuticle, EK 260 (scale bar $5 \mathrm{~mm}$ ).

5. Isolated stamen, NM-G11918c (scale bar $1 \mathrm{~mm}$ ).

6. Infructescence, Knobloch's original (1961, pl. 3, fig. 9 left, as Comptonia difformis (STERNBERG) BERRY), NM-G2830b (scale bar $5 \mathrm{~mm}$ ).

7. Isolated stipule, EK 263 (scale bar $3 \mathrm{~mm}$ ).

Cercidiphyllum crenatum (UNGER) R. BROWN

8. Impression of broad leaf, Knobloch's original (1961, pl. 15, fig. 1), NM-G2998a (scale bar $10 \mathrm{~mm}$ ).

9. Impression of elliptic leaf, Knobloch's original (1961, pl. 15, fig. 3), NM-G8595 (scale bar $10 \mathrm{~mm}$ ).

\section{PLATE 8}

\section{Ampelopsis hibschii BưžEK, KVAČEK et WALTHER}

1. Leaf impression, Knobloch's original (1961, pl. 8, fig. 3, as Vitis sp.), NM-G2869 (scale bar $10 \mathrm{~mm}$ ).

2. Impression of leaf apex with separated tip, EK 267 (scale bar $10 \mathrm{~mm}$ ).

3. Impression of leaf base, EK 271 (scale bar $10 \mathrm{~mm}$ ).

4. Leaf fragment with separated tip, EK 270 (scale bar $10 \mathrm{~mm})$.

5. Leaf base with petiole, Knobloch's original (1961, pl. 10, fig. 3, as Platanus cf. aceroides GöPPERT), NM-G2891 (scale bar $10 \mathrm{~mm}$ ).

6. Leaflet, Knobloch's original (1961, pl. 7, fig. 7, as Zelkova ungeri KovÁTs), NM-G2855 (scale bar $10 \mathrm{~mm}$ ).

\section{PLATE 9}

Parvileguminophyllum haeringianum (ETTINGSHAUSEN) KVAČEK comb. $n$.

1. Leaflet, Knobloch's original (1961, pl. 14, fig. 8, as Mimosites cf. haeringiana EtINGSHAUSEN), NM-G8583 (scale bar $3 \mathrm{~mm}$ ).

2. Leaflet, Knobloch's original (1961, pl. 12, fig. 1, as Mimosites cf. haeringiana ETTINGSHAUSEN), NM-G8592 (scale bar $3 \mathrm{~mm}$ ).

3. Leaflet, NM-G11487 (scale bar 3 mm). 
Phaseolites sp. 1

4. Leaflet base, Knobloch's original (1961, pl. 5, fig. 15), NM-G2839 (scale bar $5 \mathrm{~mm}$ ).

\section{Phaseolites sp. 3}

5. Fragmentary long petiolate leaf with fragmentary leaflets, Knobloch's original (1961, pl. 11, fig. 5, as ?Cassia sp.), NM-G2903 (scale bar $5 \mathrm{~mm}$ ).

\section{Phaseolites sp. 4}

6. Emarginate leaflet, Knobloch's original (1961, pl. 10, fig. 10, as Dalbergia bella HeER), NM-G2862b (scale bar $5 \mathrm{~mm})$.

\section{Phaseolites sp. 2}

7. Leaflet base, EK 276 (scale bar $5 \mathrm{~mm}$ ).

8. Leaflet base, Knobloch's original (1961, pl. 8, fig. 10, as Leguminosites sp.), NM-G2868 (scale bar $5 \mathrm{~mm}$ ).

\section{PLATE 10}

\section{Rosa lignitum HEER}

1. Leaflet, Knobloch's original (1961, pl. 8, fig. 2, as ? Rhus pyrrhae UNGER), NM-G2866 (scale bar $5 \mathrm{~mm}$ ).

2. Leaflet, NM-G2876b (scale bar $5 \mathrm{~mm}$ ).

3. Leaflet, EK 285 (scale bar $5 \mathrm{~mm}$ ).

4. Leaflet, EK 282 (scale bar $5 \mathrm{~mm}$ ).

5. Small leaflet, EK 284 (scale bar $5 \mathrm{~mm}$ ).

6. Small leaflet, EK 283 (scale bar $5 \mathrm{~mm}$ ).

7. Leaflet, EK 280 (scale bar $5 \mathrm{~mm}$ ).

8. Leaflet, Knobloch's original (1961, pl. 9, fig. 11, as ? Rhus pyrrhae UNGER), NM-G2871 (scale bar $5 \mathrm{~mm}$ ).

9. Leaflet, EK 279 (scale bar $5 \mathrm{~mm}$ ).

\section{Crataegus pirskenbergensis KNOBLOCH}

10. Leaf impression, Knobloch's original (1961, pl. 8, fig. 7), NM-G2861a (scale bar $10 \mathrm{~mm}$ ).

11. Leaf impression, Knobloch's original (1961, pl. 8, fig. 8, holotype), NM-G2867a (scale bar $10 \mathrm{~mm}$ ).

\section{PLATE 11}

\section{Ulmus fischeri HEER}

1. Leaf impression, Knobloch's original (1961, pl. 1, fig. 7, as Zelkova ungeri KovÁTs), NM-G2807 (scale bar $10 \mathrm{~mm}$ ).

2. Narrow leaf impression, Knobloch's original, (1961, pl. 1, fig. 2, as Zelkova ungeri KovÁTs), NM-G2804 (scale bar $5 \mathrm{~mm}$ ).

3. Leaf base, Knobloch's original (1961, pl. 7, fig. 4, as Zelkova ungeri Kováts), NM-G2868 (scale bar $5 \mathrm{~mm}$ ).

4. Leaf impression, EK 287 (scale bar $10 \mathrm{~mm}$ ).

\section{Zelkova zelkovifolia (UNGER) BŮŽEK et KOTLABA}

5. Leaf base, EK 288 (scale bar $10 \mathrm{~mm}$ ).

\section{PLATE 12}

Celtis pirskenbergensis (KNOBLOCH) KVAČEK et WALTHER

1. Leaf base, Knobloch's original (1961, pl. 6, fig. 9, as Celtis begonioides GÖPPERT), NM-G2851a (scale bar $10 \mathrm{~mm}$ ).

2. Leaf apex, Knobloch's original (1961, pl. 6, fig. 5, as Celtis begonioides GÖPPERT var. pirskenbergensis KNOBLOCH), NM-G2852 (scale bar $10 \mathrm{~mm}$ ).

3. Leaf impressions showing leaf apex and a part of the base, Knobloch's original (1961, pl. 6, fig. 8, as Celtis begonioides GÖPPERT var. pirskenbergensis KNOBLOCH, holotype), NM-G2850a (scale bar $10 \mathrm{~mm}$ ).

4. Leaf fragment, NM-G2979, Knobloch's original (1961, not figured, as Celtis begonioides GÖPPERT var. pirskenbergensis KNOBLOCH) (scale bar $10 \mathrm{~mm}$ ).

5. Leaf fragment, counterimpression to Knobloch's original (1961, pl. 6, fig. 3, as Celtis begonioides GÖPPERT var. pirskenbergensis KNOBLOCH), NM-G2853b (scale bar $10 \mathrm{~mm})$.

6. Leaf base, Knobloch's original (1961, pl. 12, fig. 4, as Celtis begonioides GÖPPERT), NM-G8600 (scale bar $10 \mathrm{~mm})$.

\section{PLATE 13}

\section{Comptonia difformis (STERNBERG) BERRY}

1. Leaf apex, EK 209 (scale bar $10 \mathrm{~mm}$ ).

2. Middle part of leaf, Knobloch's original (1961, pl. 3, fig. 10), NM-G2827 (scale bar $10 \mathrm{~mm}$ ).

3. Fragmentary leaf compression with cuticle, NM-G11506a (scale bar $5 \mathrm{~mm}$ ).

4. Almost complete leaf, EK 298 (scale bar $10 \mathrm{~mm}$ ).

5. Narrow leaf without apex, EK 300 (scale bar 10mm).

6. Lower part of leaf, Knobloch's original (1961, pl. 3, fig. 6), NM-G2826 (scale bar $10 \mathrm{~mm}$ ).

7. Magnified base of the previous specimen NM-G2826 (scale bar $5 \mathrm{~mm}$ ).

8. Minute leaf impression, NM-G2987 (scale bar $1.5 \mathrm{~mm}$ ).

9. Narrow leaf without apex, EK 291 (scale bar $10 \mathrm{~mm}$ ).

\section{PLATE 14}

\section{Engelhardia orsbergensis (WESSEL et WEBER) JÄHNICHEN,} Mai et WaLther

1. Leaflet, Knobloch's original (1961, pl. 12, fig. 5, as Myrica lignitum (Unger) SAPORTA), NM-G8582 (scale bar $10 \mathrm{~mm})$.

2. Leaflet fragment, Knobloch's original (1961, pl. 1, fig. 13, as Myrica lignitum (UNGER) SAPORTA), NM-G2805 (scale 10 bar $\mathrm{mm}$ ).

3. Large leaflet, NM-G11515b (scale bar $10 \mathrm{~mm}$ ).

4. Leaflet fragment, Knobloch's original (1961, pl. 2, fig. 10, as Myrica lignitum (UNGER) SAPORTA), NM-G2824 (scale bar $10 \mathrm{~mm}$ ).

5. Fragmentary compression of base with cuticle, NM-G11511a (scale bar $5 \mathrm{~mm}$ ).

\section{Engelhardia macroptera (BRONGNIART) UNGER}

6. Fragmentary involucre, EK 312 (scale bar $10 \mathrm{~mm}$ ).

\section{Carya fragiliformis (STERNBERG) KVAČEK et WALTHER}

7. Leaflet base, counter-impression to Knobloch's original (1961, pl. 9, fig. 12, as Carya serraefolia (GÖPPERT) KRÄUSEL), NM-G2878b (scale bar $10 \mathrm{~mm}$ ). 


\section{Cyclocarya sp.}

8. Upper part of compound leaf, Knobloch's original (1961, pl. 15, fig. 6, as Cyclocarya cyclocarpa (SCHLECHTENDAL) KNOBLOCH), NM-G2932 (scale bar $10 \mathrm{~mm}$ ).

\section{PLATE 15}

\section{Betula alboides ENGELHARDT}

1. Fragmentary leaf, Knobloch's original (1961, pl. 14, fig. 3, as Betula cf. dryadum BRONGNIART), NM-G8588 (scale bar $10 \mathrm{~mm}$ ).

2. Almost complete leaf, EK 324 (scale bar $5 \mathrm{~mm}$ ).

\section{Betula buzekii KVAČEK et WALTHER}

3. Almost complete leaf, Knobloch's original (1961, pl. 5, fig. 11, as Betula prisca EtTingshausen), NM-G2847 (scale bar $10 \mathrm{~mm}$ ).

4. Almost complete leaf, Knobloch's original (1961, pl. 5, fig. 4, as Betula prisca EtTingshausen), NM-G2848 (scale bar $10 \mathrm{~mm}$ ).

\section{Alnus gaudinii (HEER) KNOBLOCH et KVAČEK}

5. Leaf base, EK 339 (scale bar $10 \mathrm{~mm}$ ).

6. Leaf base, EK 330 (scale bar $10 \mathrm{~mm}$ ).

7. Leaf impression, Knobloch's original (1961, pl. 11, fig. 10, as ? Pterocarya aff. castaneaefolia (GÖPPERT) SCHLECHTENDAL), NM-G8603 (scale bar $10 \mathrm{~mm}$ ).

\section{Alnus kefersteinii (GÖPPERT) UNGER}

8. Infructescence, Knobloch's original (1961, pl. 2, fig. 12, as Alnus sp.), NM-G2819a (scale bar $5 \mathrm{~mm}$ ).

9. Male catkin, Knobloch's original (1961, pl. 5, fig. 14, as Betula sp.), NM-G2840 (scale bar 5 mm).

\section{PLATE 16}

\section{Carpinus grandis UNGER}

1. Leaf impression, Knobloch's original (1961, pl. 14, fig. 1, as Carpinus orientalis GAUdin et STROzZI), NM-G8587 (scale bar $10 \mathrm{~mm}$ ).

\section{Carpinus roscheri KVAČEK et WALTHER}

2. Smaller leaf fragment, Knobloch's original (1961, pl. 2, fig. 6, as Betula brongniartii ETTINGSHAUSEN), NM-G2817 (scale bar $10 \mathrm{~mm}$ ).

3. Base of leaf fragment, Knobloch's original (1961, not figured, as Betula brongniartii EtTINGSHAUSEN), NM-G2981 (scale bar $10 \mathrm{~mm}$ ).

\section{Carpinus medimontana MAI}

4. Involucre, EK 256 (scale bar $5 \mathrm{~mm}$ ).

5. Involucre, NM-G2998b (scale bar $5 \mathrm{~mm}$ ).

\section{Carpinus cordataeformis MAI}

6. Involucre, NM-G2995b (scale bar $5 \mathrm{~mm}$ ).

7. Involucre, EK 349 (scale bar $5 \mathrm{~mm}$ ).

\section{PLATE 17}

\section{Salix sp.}

1. Almost complete leaf, Knobloch's original (1961, pl. 1, fig. 9, as Populus rottensis WEYLAND), NM-G2806 (scale bar $10 \mathrm{~mm}$ ).

2. Leaf tip, EK 360a (scale bar $10 \mathrm{~mm}$ ).

3. Upper part of leaf, NM-G2995c (scale 10 bar mm).

\section{Populus zaddachii HeER}

4. Long petiolate leaf base, Knobloch's original (1961, not figured), NM-G8590 (scale bar $10 \mathrm{~mm}$ ).

5. Leaf blade, Knobloch's original (1961, not figured), NM-G8579a (scale bar $10 \mathrm{~mm}$ ).

6. Leaf apex, EK 359 (scale bar $10 \mathrm{~mm}$ ).

\section{PLATE 18}

Toxicodendron herthae (UNGER) KVAČEK et WALTHER

1. Leaflet apex, counter-impression to Knobloch's original (1961, pl. 13, fig. 4, as Rhus herthae UNGER) NM-G2916b (scale bar $10 \mathrm{~mm}$ ).

\section{Acer angustilobum HEER}

2. Small leaf, EK 363 (scale bar $5 \mathrm{~mm}$ ).

3. Leaf fragment with cuticle shown in Pl. 6, Fig. 9, NM-G11505a (scale bar $10 \mathrm{~mm}$ ).

\section{Acer integrilobum WEBER}

4. Small leaf, EK 362 (scale bar $10 \mathrm{~mm}$ ).

\section{Acer sp.}

5. Winged mericarp, Knobloch's original (1961, pl. 11, fig. 8, as Acer sp.), NM-G8596 (scale bar mm).

\section{Acer palaeosaccharinum STUR}

6. Long petiolate leaf, Knobloch's original (1961, pl. 9, fig. 5), NM-G2872 (scale bar $5 \mathrm{~mm}$ ).

7. Broad leaf, Knobloch's original (1961, pl. 1, fig. 11), NM-G2814 (scale bar $10 \mathrm{~mm}$ ).

\section{PLATE 19}

Craigia bronnii (Unger) KVAČEK, BƯŽK et MANCHeSTer

1. Fruit valve, EK 374 (scale bar $5 \mathrm{~mm}$ ).

2. Incomplete fruit valve, EK 375 (scale bar $5 \mathrm{~mm}$ ).

\section{Hydrangea microcalyx SIEBER}

3. Petaloid sepal, Knobloch's original (1961, pl. 11, fig. 11, as Paliurus thurmannii HeER), NM-G8585 (scale bar $5 \mathrm{~mm})$.

\section{Cornus studeri HeER}

4. Basal part of leaf, Knobloch's original (1961, pl. 13, fig. 1), NM-G8606 (scale bar $10 \mathrm{~mm}$ ).

\section{Oleinites hallbaueri (MAI) SACHSE}

5. Leaf fragment with cuticle, Knobloch's original (1961, pl. 1, fig. 8, as Myrica lignitum (UNGER) SAPORTA), NM-G2812a (scale bar $10 \mathrm{~mm}$ ). 
6. Almost complete leaf, Knobloch's original (1961, pl. 3, fig. 1, as Myrica lignitum (UnGER) SAPORTA), NM-G4859a (scale bar $10 \mathrm{~mm}$ ).

7. Detailed venation of the previous specimens, NM-G4859a (scale bar $5 \mathrm{~mm}$ ).

\section{PLATE 20}

\section{Dicotylophyllum sp. 1}

1. Leaf fragment, Knobloch's original (1961, pl. 4, fig. 2, as Juglans acuminate A. BRAUN), NM-G2834 (scale bar $10 \mathrm{~mm})$.

\section{Dicotylophyllum sp. 2}

2. Long petiolate leaf base, EK 383 (scale bar $5 \mathrm{~mm}$ ).

3. Petiolate leaf base, Knobloch's original (1961, pl. 14, fig. 6, as Leguminosites sp.), NM-G8597a (scale bar $5 \mathrm{~mm}$ ).

\section{Dicotylophyllum sp. 3}

4. Leaf fragment, Knobloch's original (1961, pl. 4, fig. 9, as Juglands (Carya) bilinica UNGER), NM-G2837 (scale bar $10 \mathrm{~mm})$.

\section{Dicotylophyllum cf. heerii (ENGELHARDT) KVAČEK et WATHER} 5. Petiolate leaf base, NM-G11512 (scale bar $5 \mathrm{~mm}$ ).

\section{Dicotylophyllum sp. 6}

6. Small complete leaf, Knobloch's original (1961, pl. 14, fig. 6, as Celastrus persei UNGER), NM-G2862 (scale bar $5 \mathrm{~mm})$.

\section{Dicotylophyllum sp. 5}

7. Leaf base, Knobloch's original (1961, pl. 1, fig. 6, as Aesculus cf. palaeocastanum EtTINGSHAUSEN), NM-G2806a (scale bar $10 \mathrm{~mm}$ ).

\section{Dicotylophyllum sp. 4}

8. Leaf without base, Knobloch's original (1961, pl. 8, fig. 12, as Sibirea rottensis WEYLAND), NM-G28089 (scale bar $5 \mathrm{~mm}$ ).

Saportaspermum cf. occidentale MAYER et MANCHESTER 9. Winged seed, NM-G11483 (scale bar $3 \mathrm{~mm}$ ).

\section{Carpolithes sp. 2}

10. Rounded seed?, Knobloch's original (1961, pl. 8, fig. 11, as Carpolithus sp.), NM-G2870 (scale bar $1 \mathrm{~mm}$ ).

\section{Carpolithes sp. 1}

11. Fruitlet?, Knobloch's original (1961, pl. 1, fig. 10, as ? Pisonia eocenica Ettingshausen), NM-G2813a (scale bar $1 \mathrm{~mm}$ ).

\section{PLATE 21}

View of the present landscape at the Hrazený locality, photo P. Gürtlerová 2014. 
PLATE 1
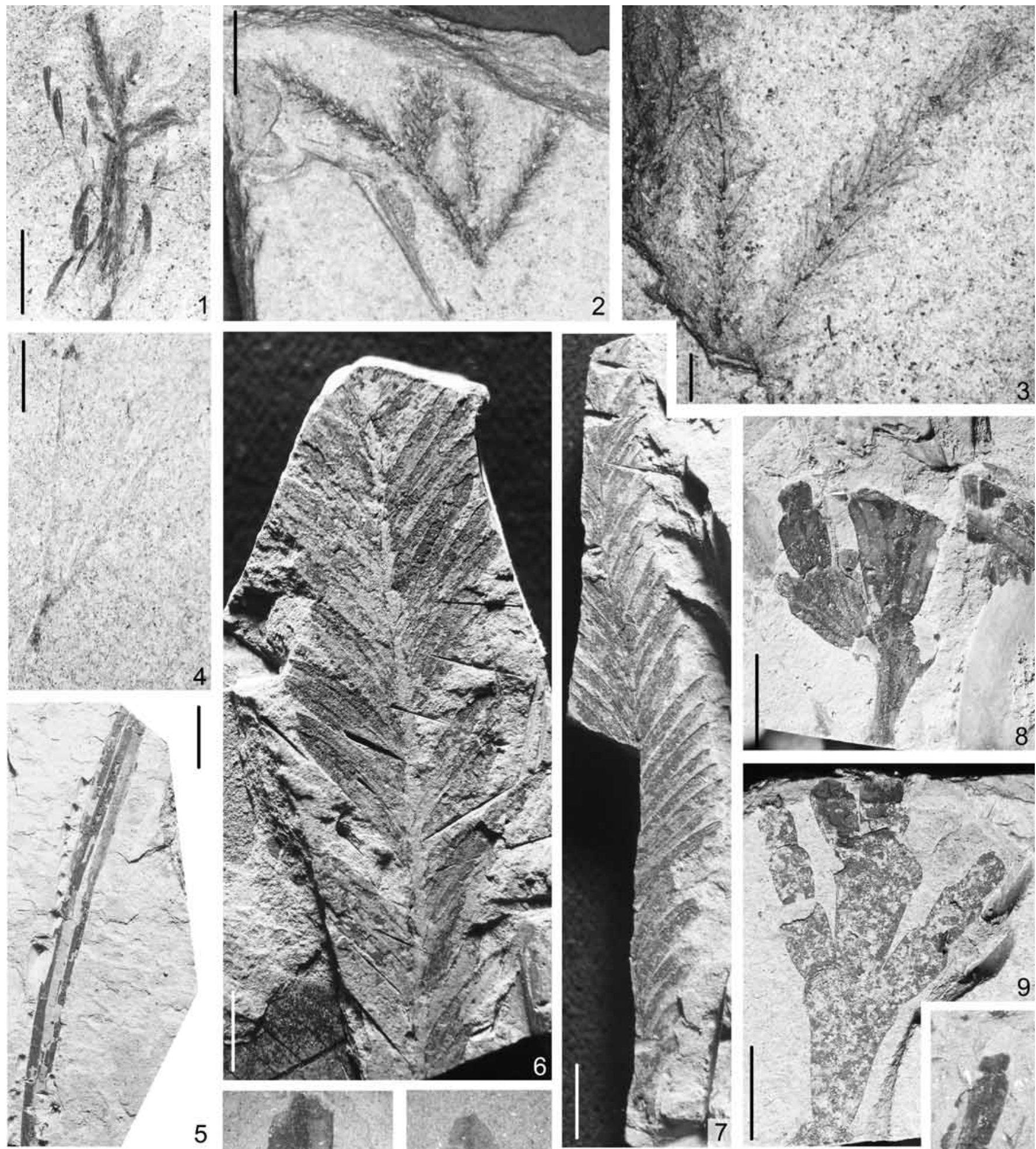

3
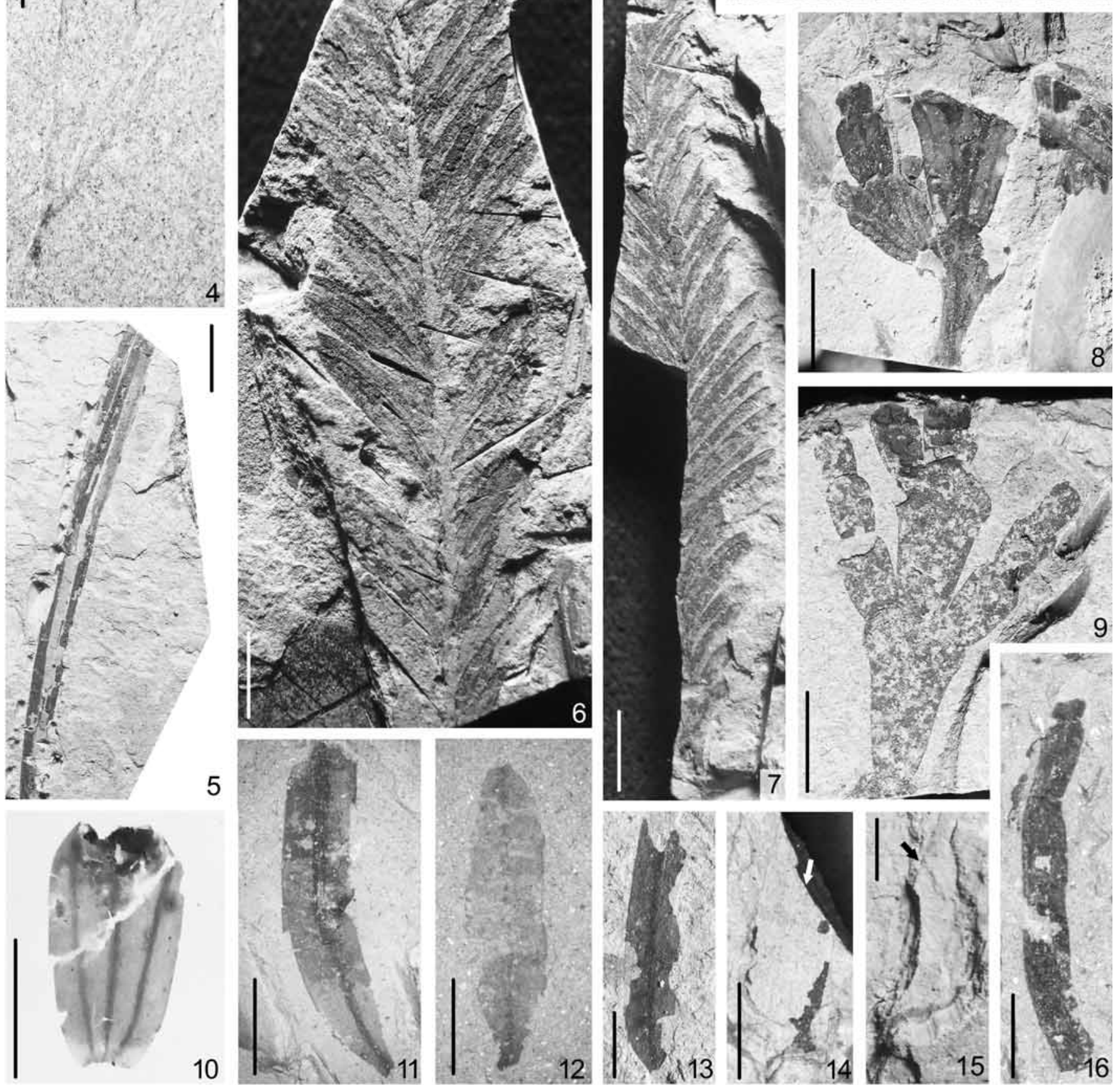

6
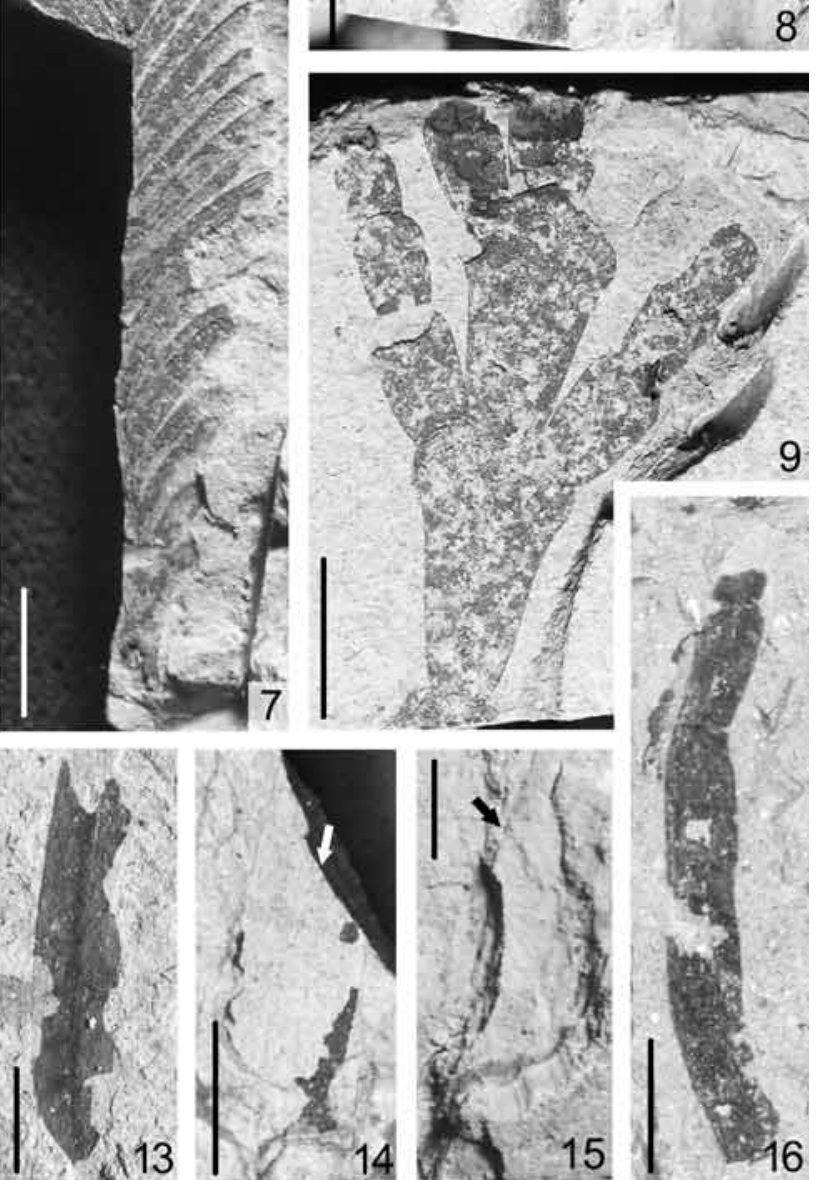
PLATE 2
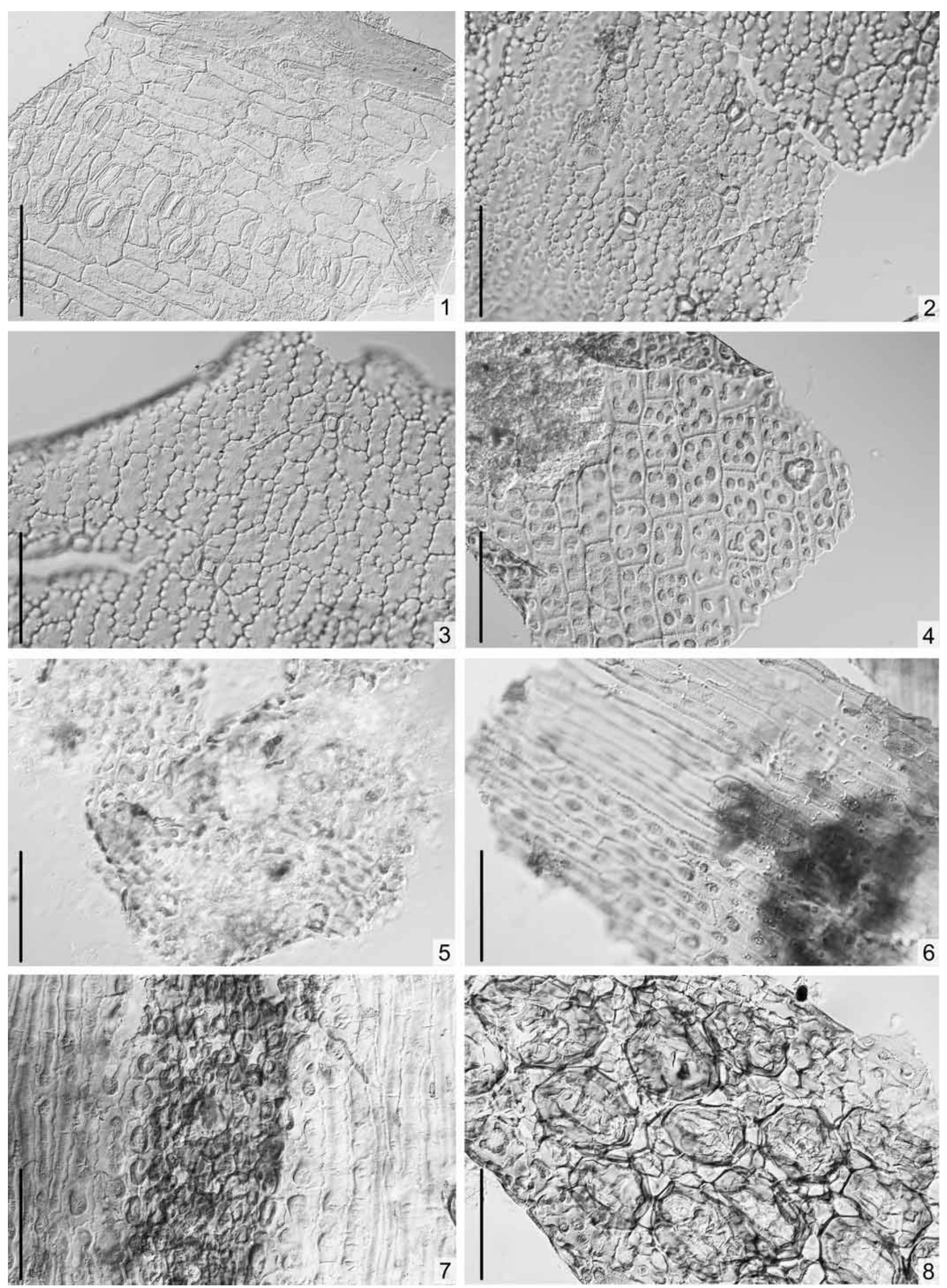
PLATE 3
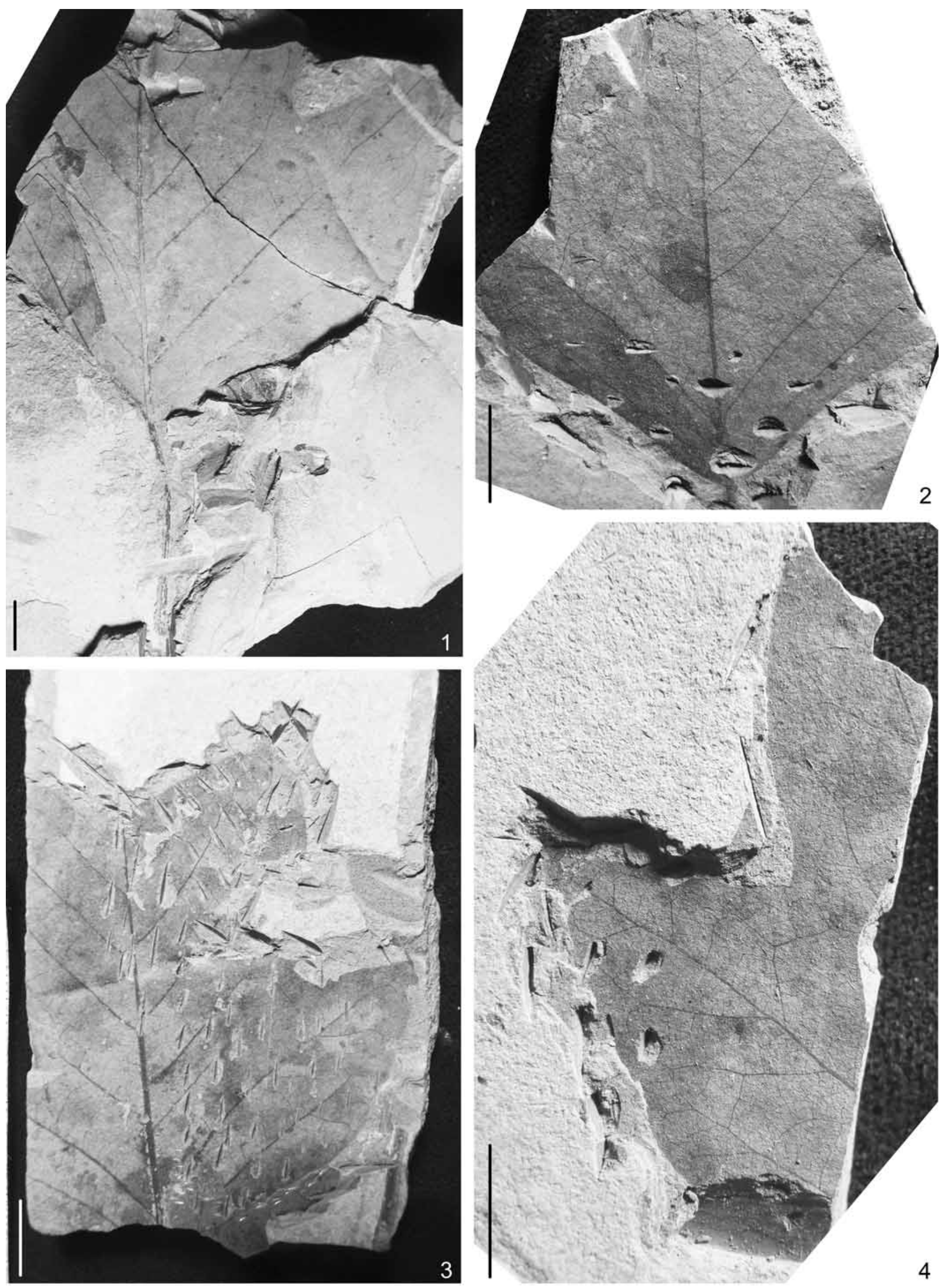
PLATE 4

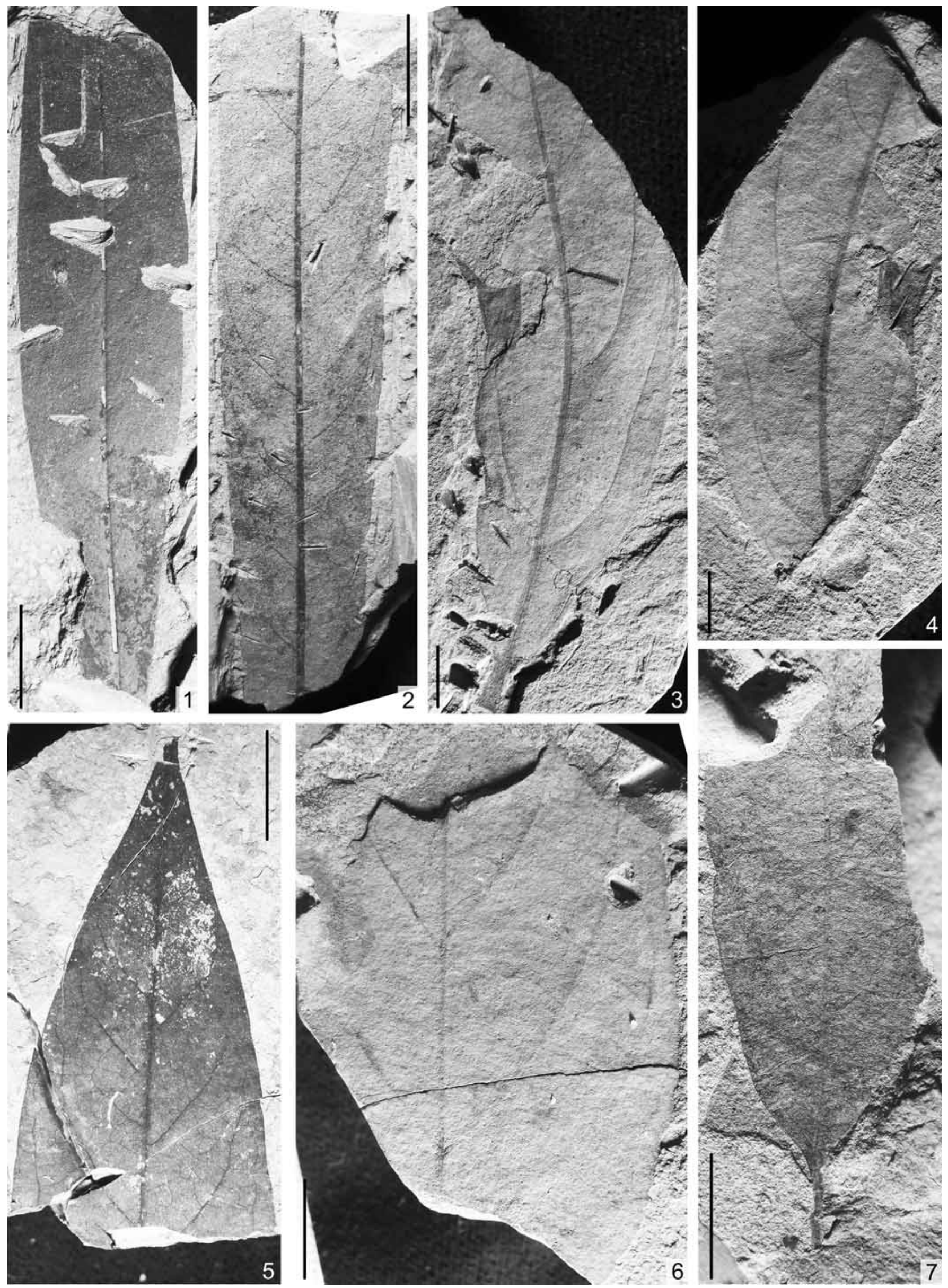




\section{PLATE 5}

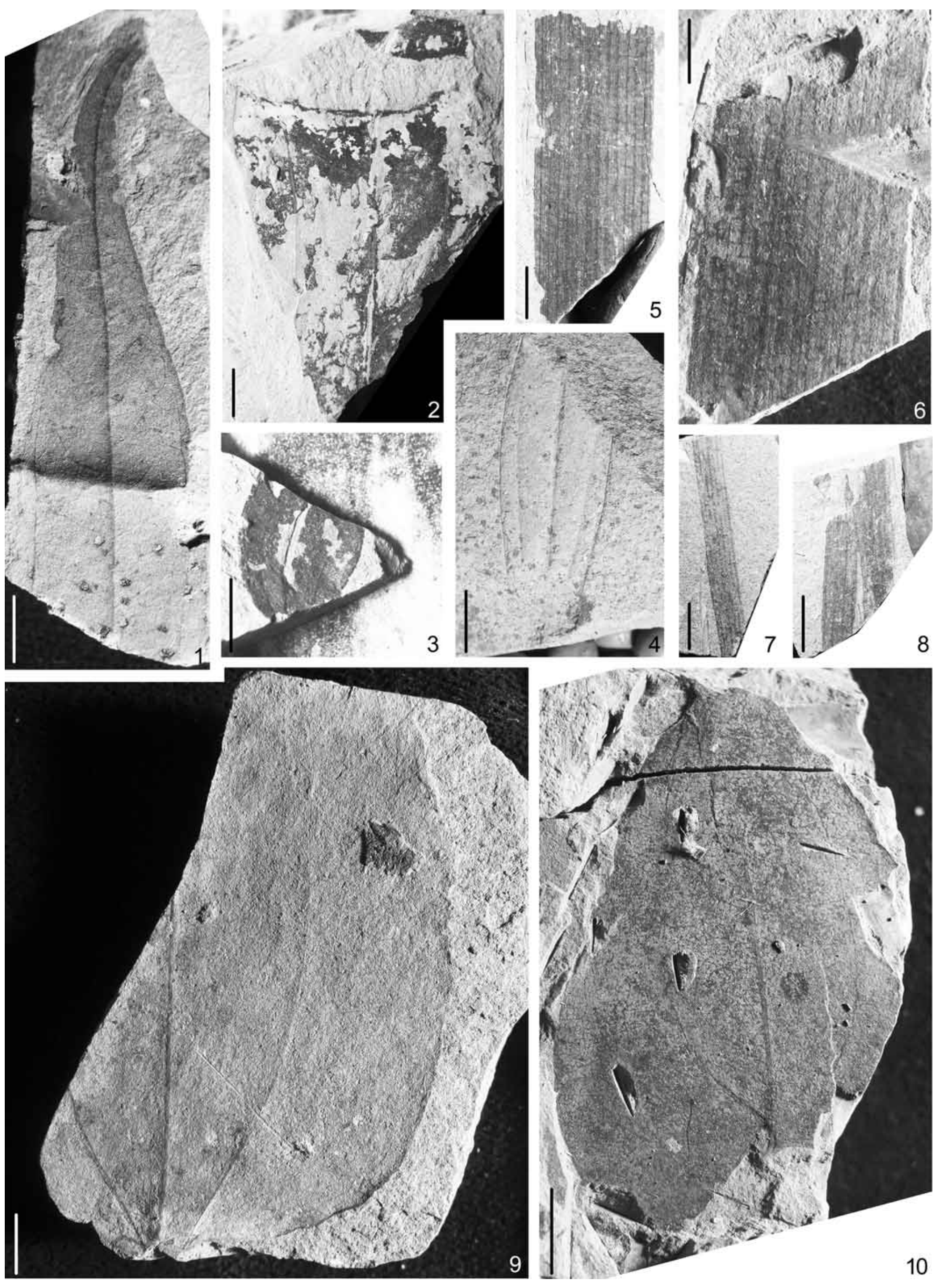


PLATE 6
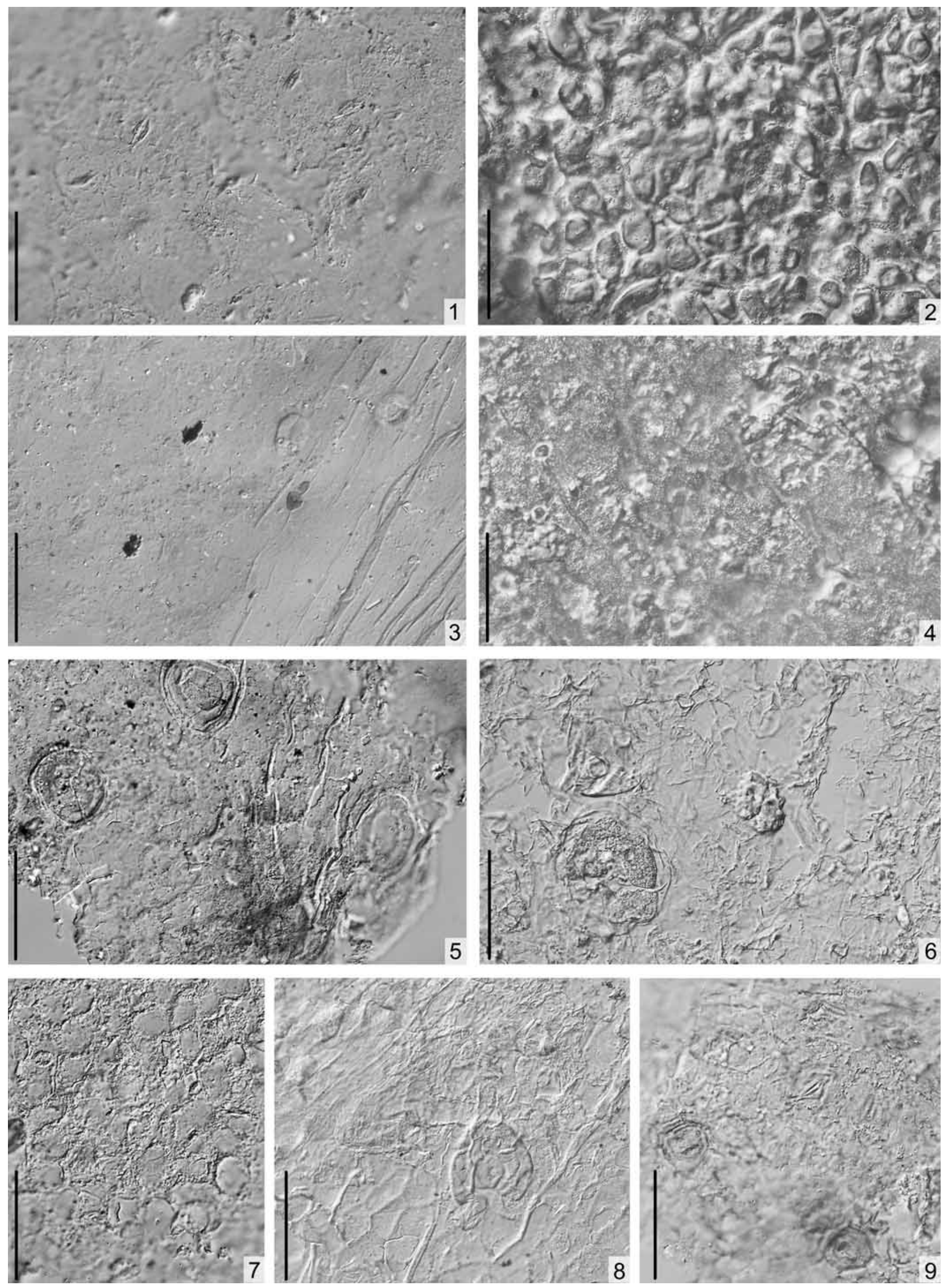
PLATE 7

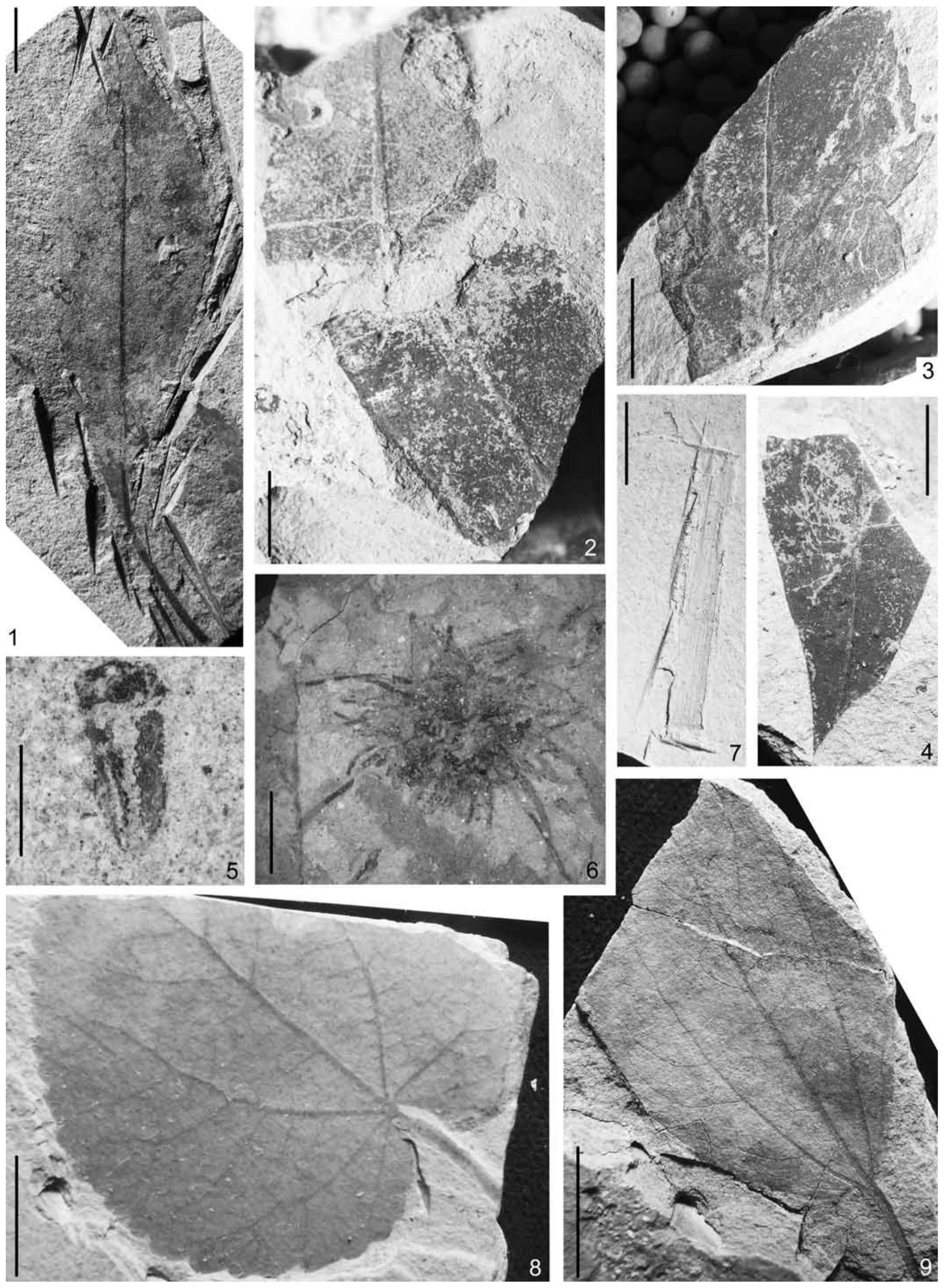


PLATE 8
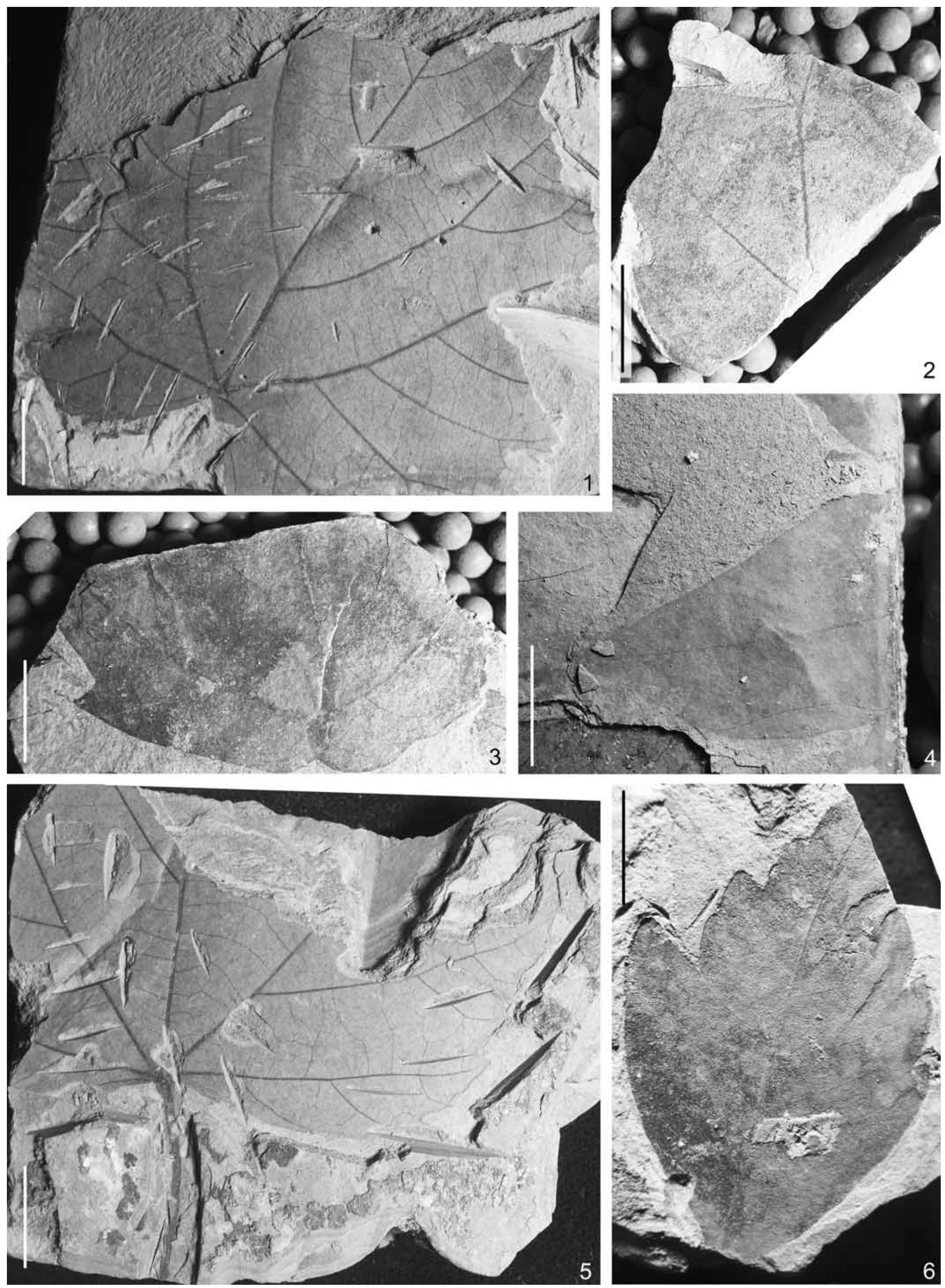


\section{PLATE 9}

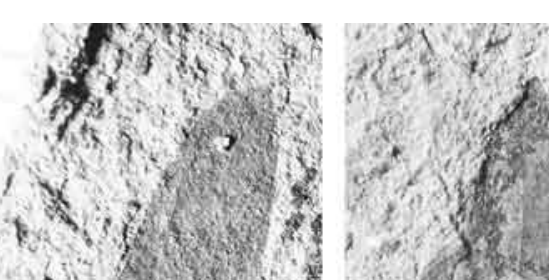

i)
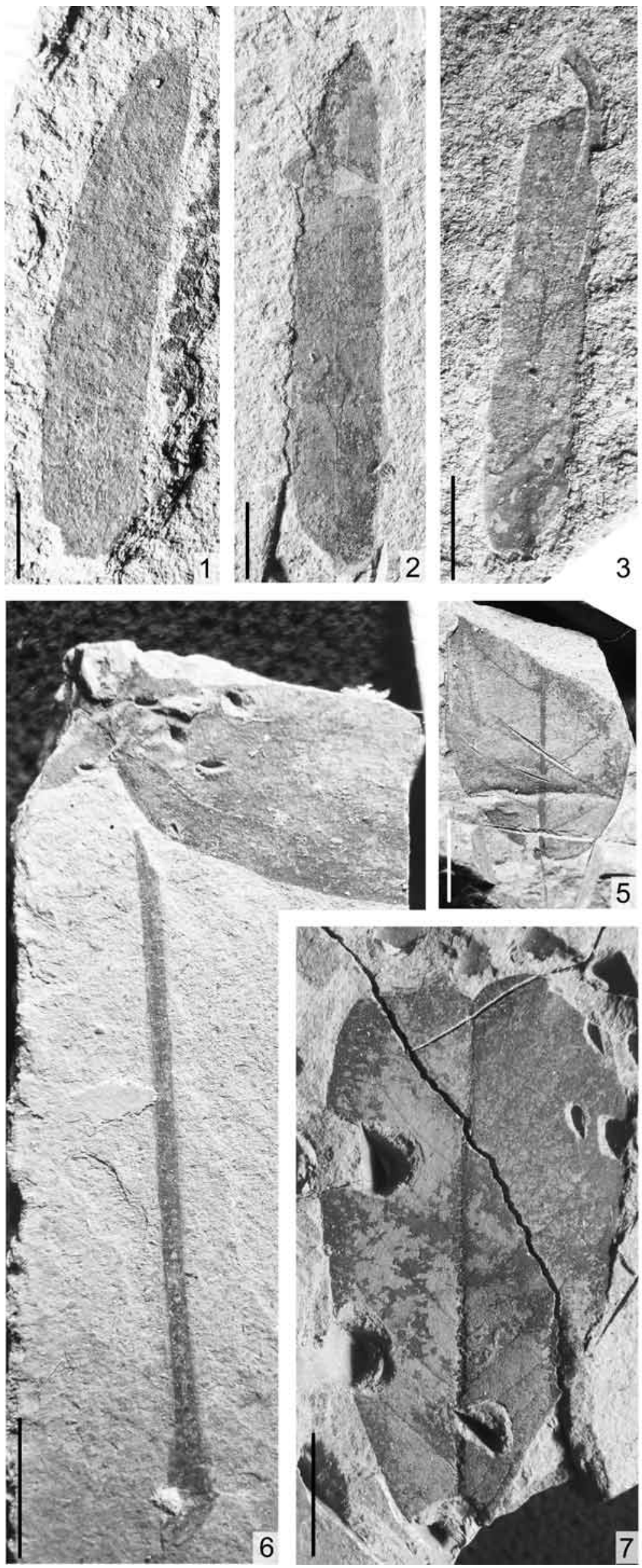

7
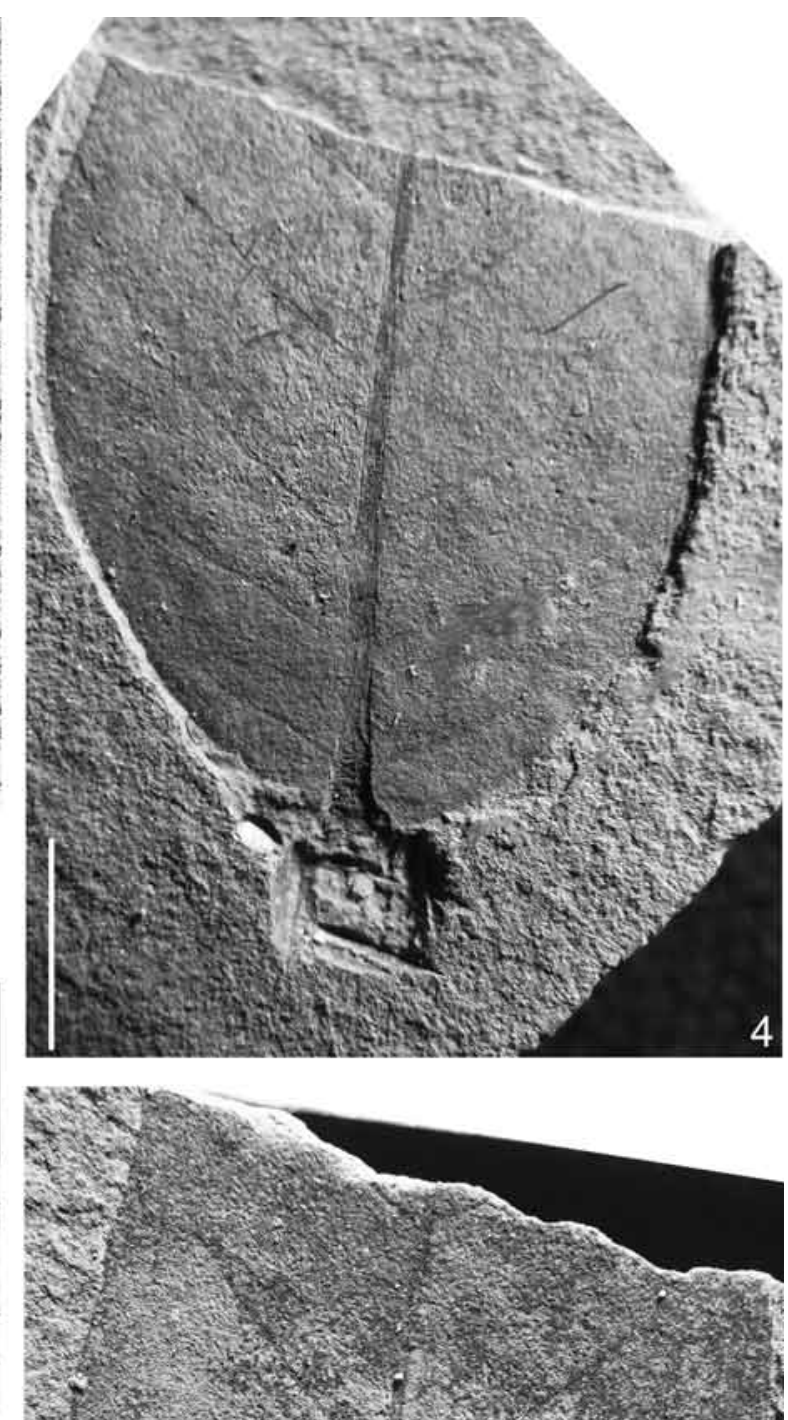

$\frac{1}{2}$
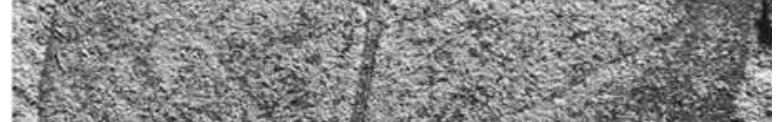

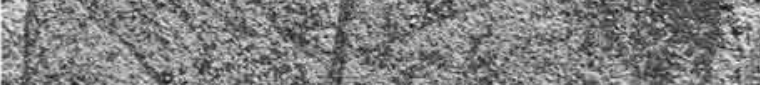

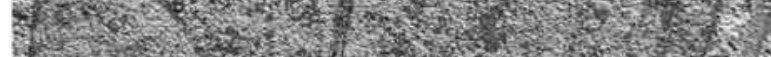

6. 20100

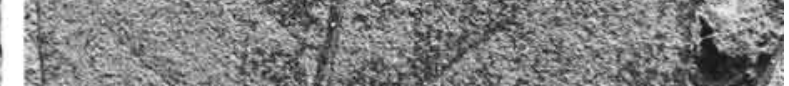

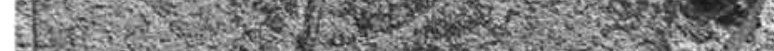

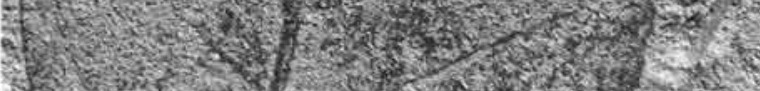

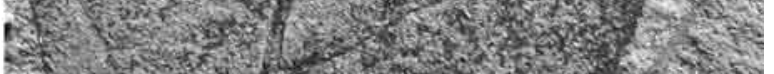

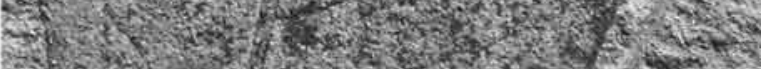

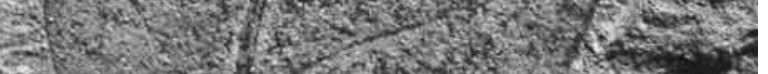

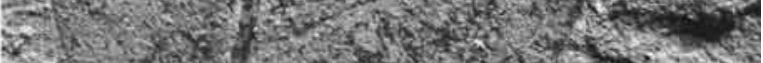

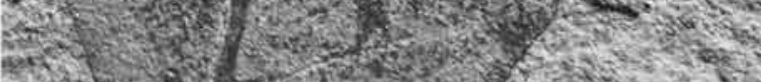

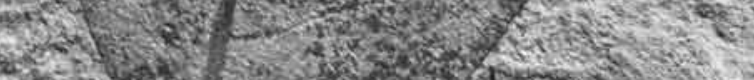

sists

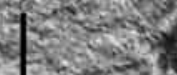

y forectist

\section{.}


PLATE 10
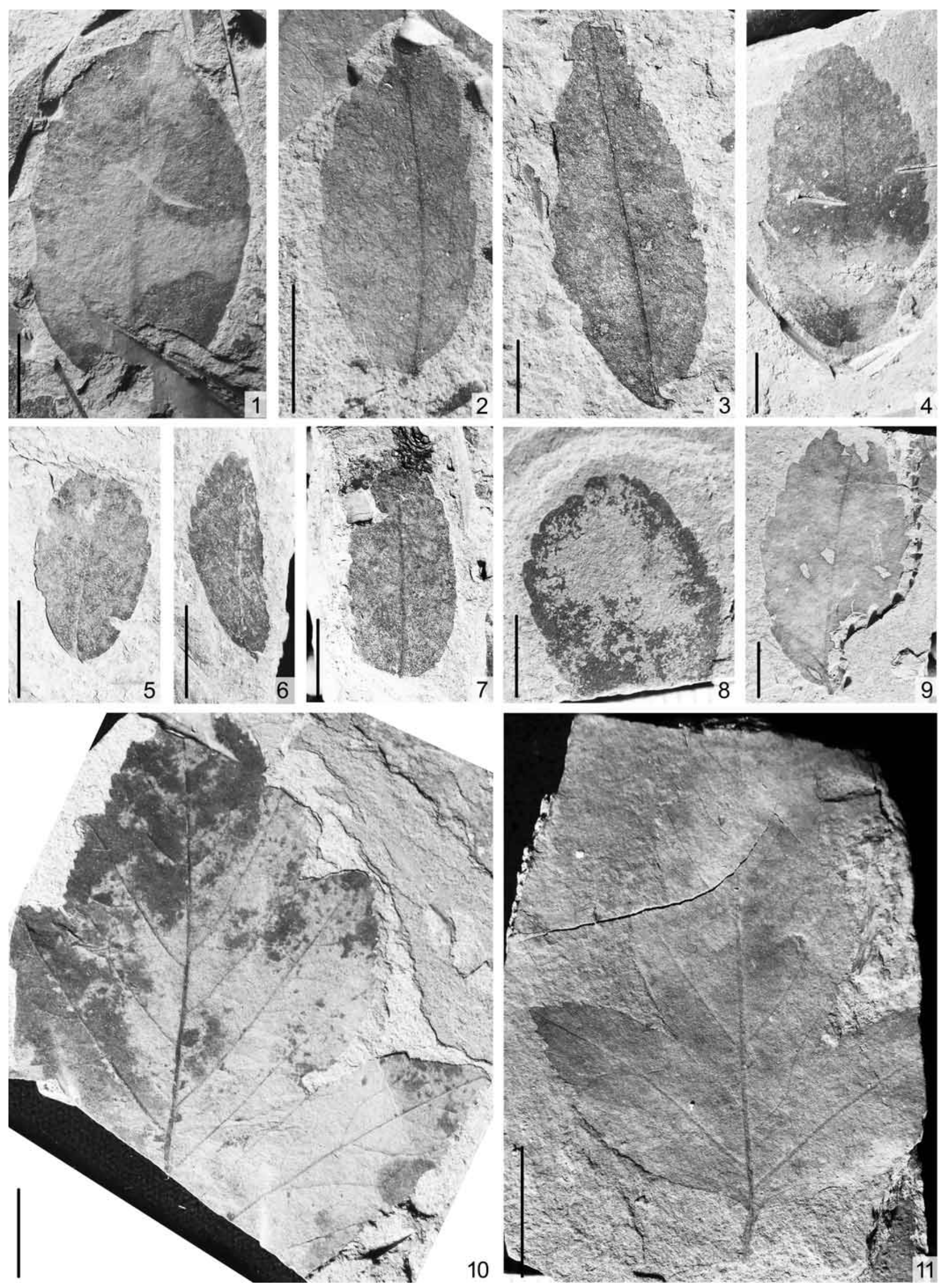


\section{PLATE 11}
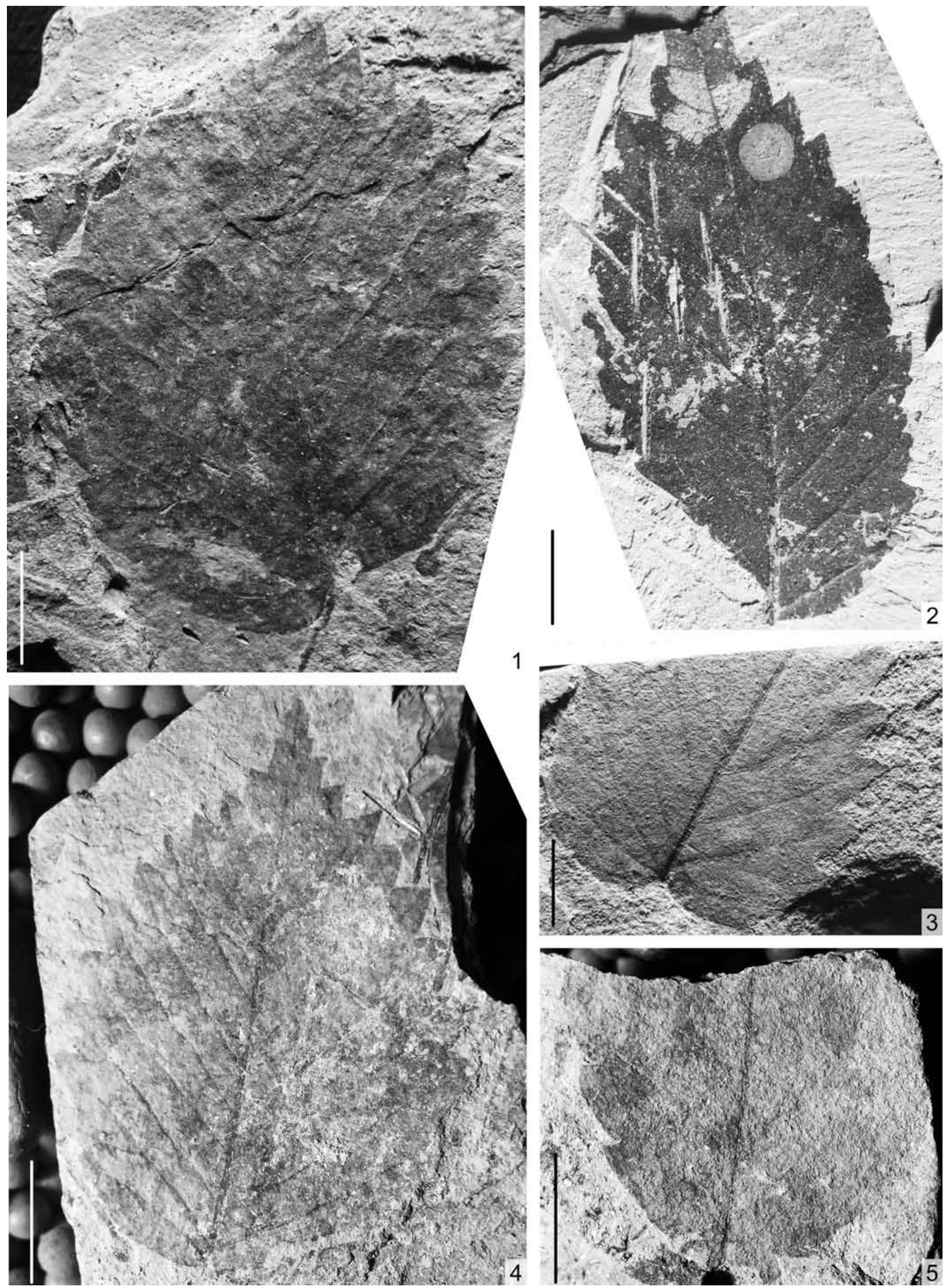
PLATE 12
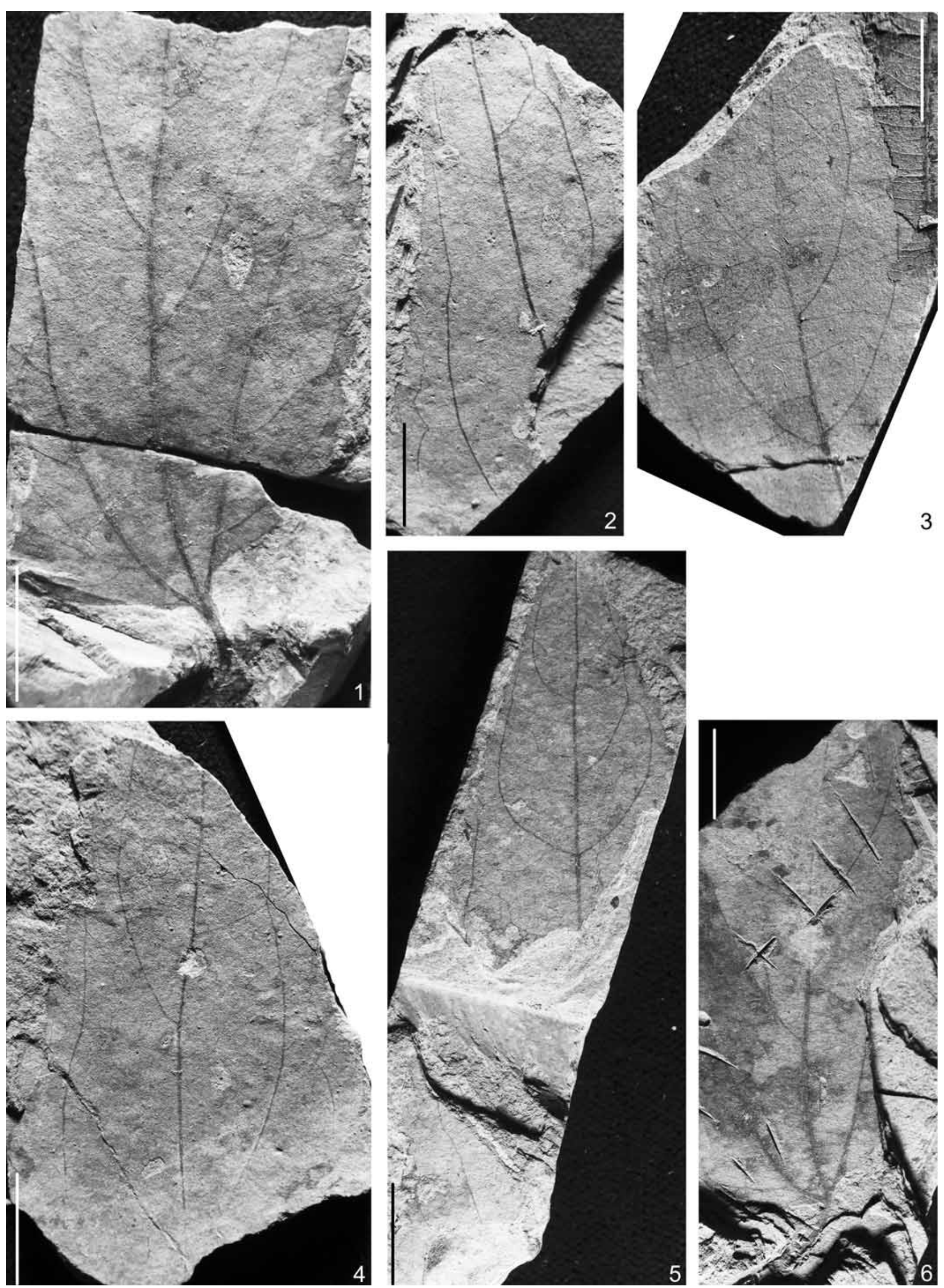
PLATE 13

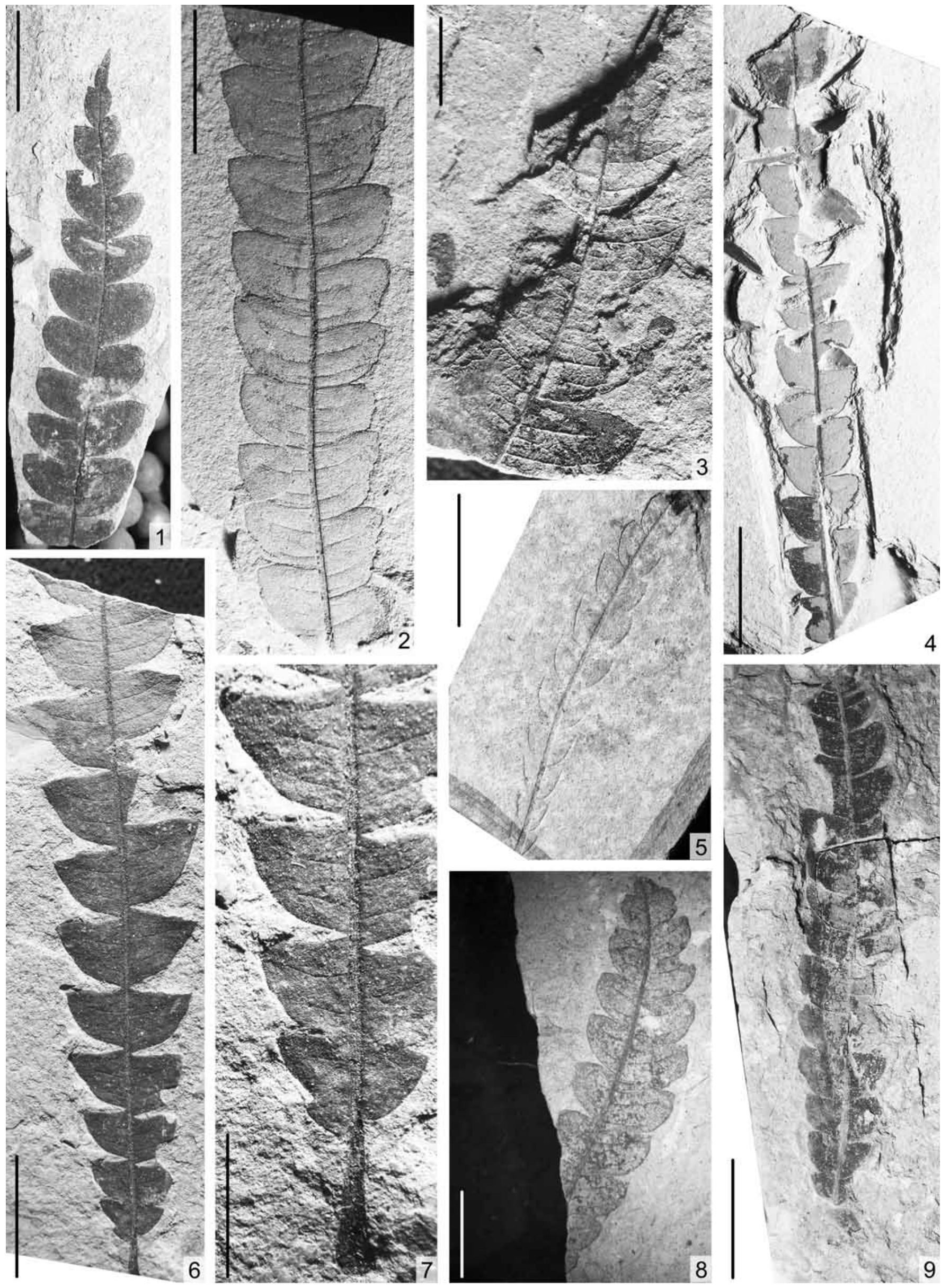


PLATE 14
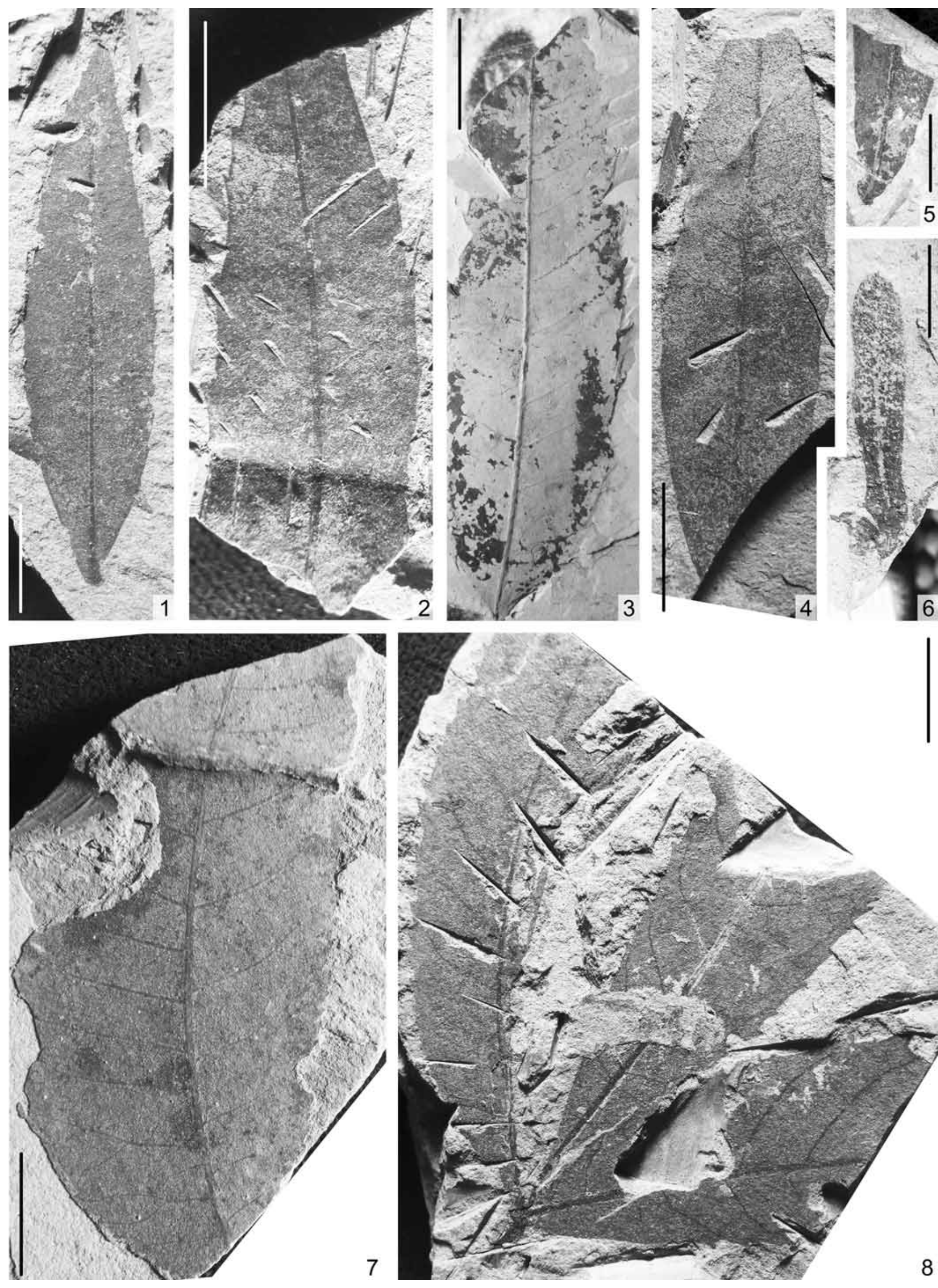

3
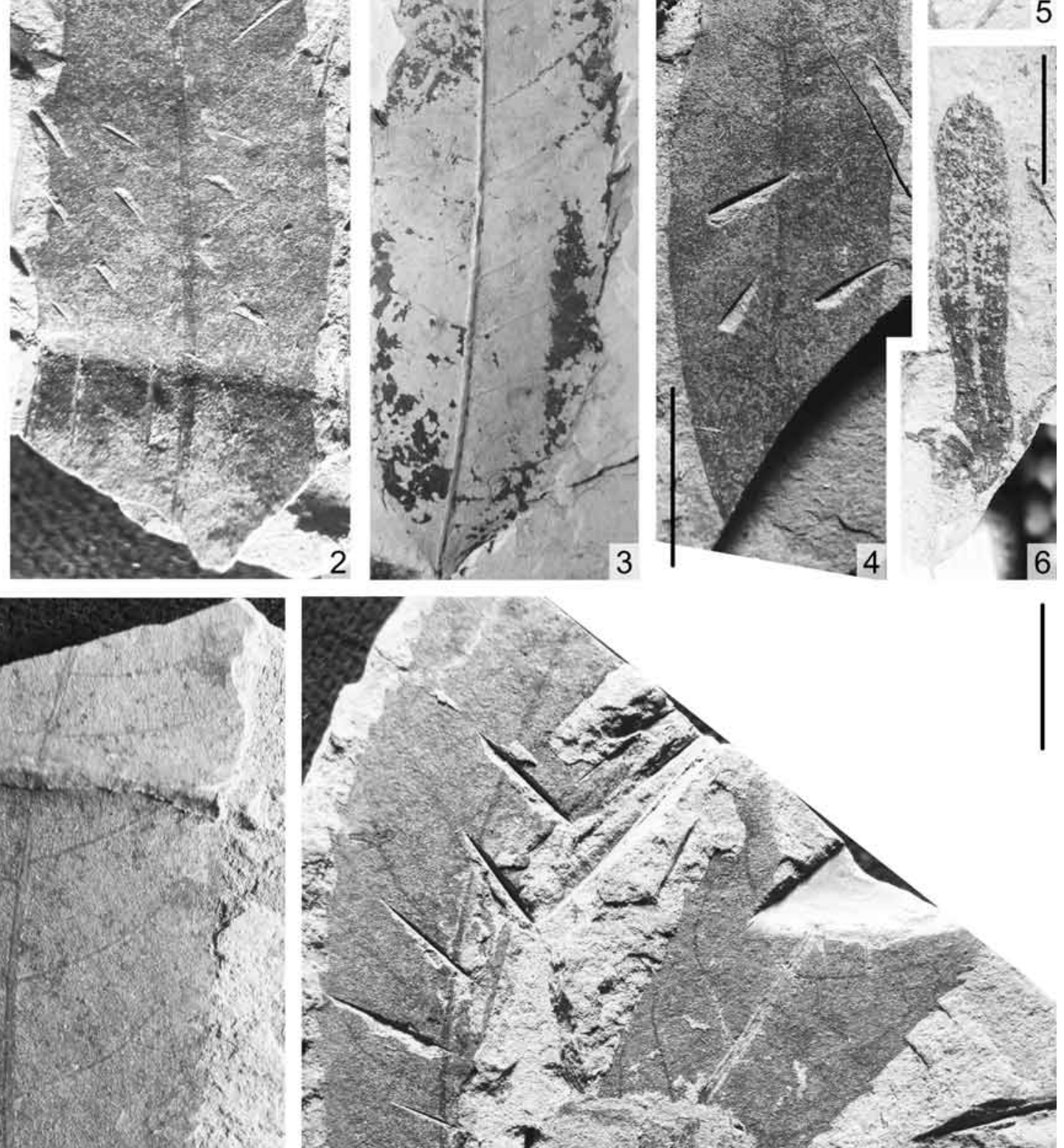

7

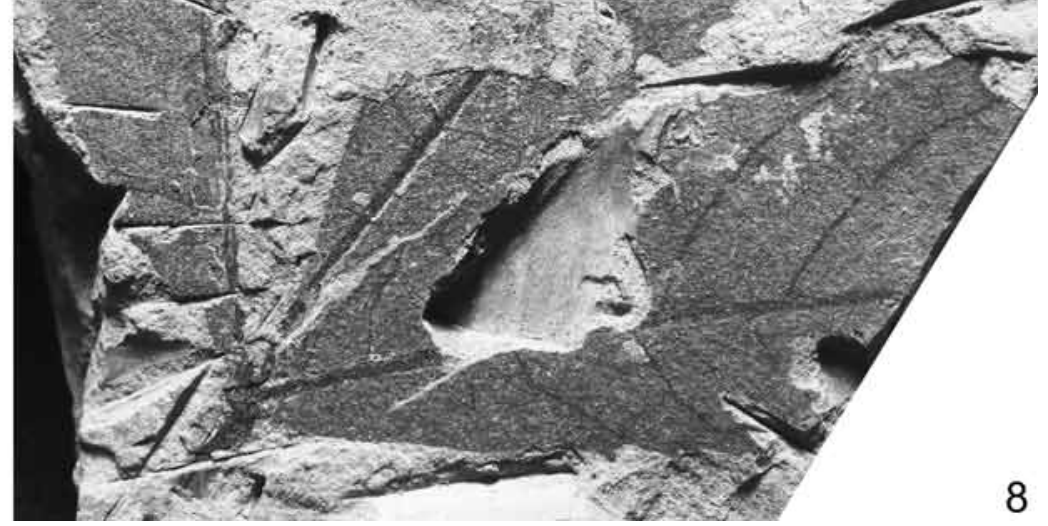




\section{PLATE 15}

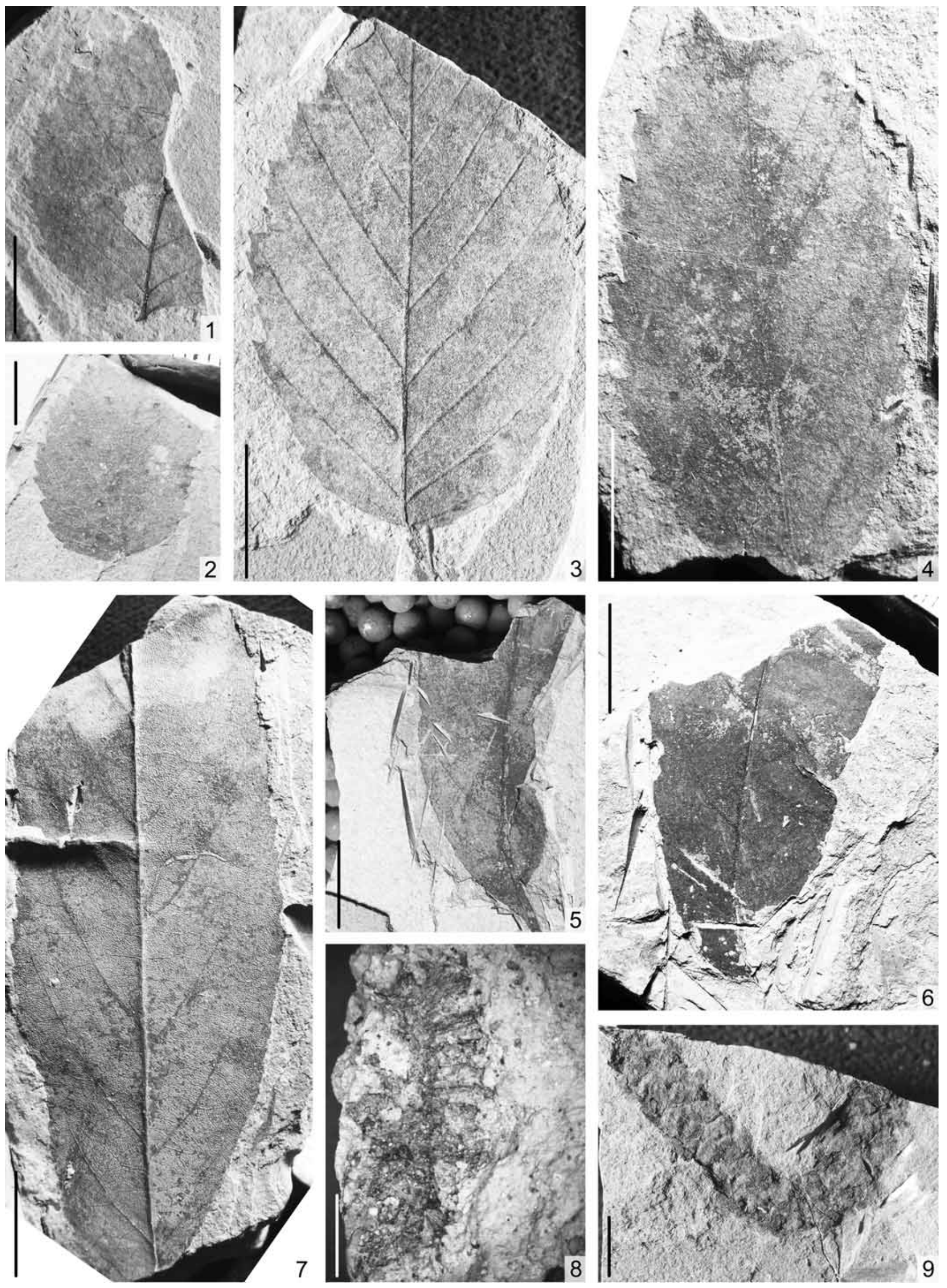


PLATE 16
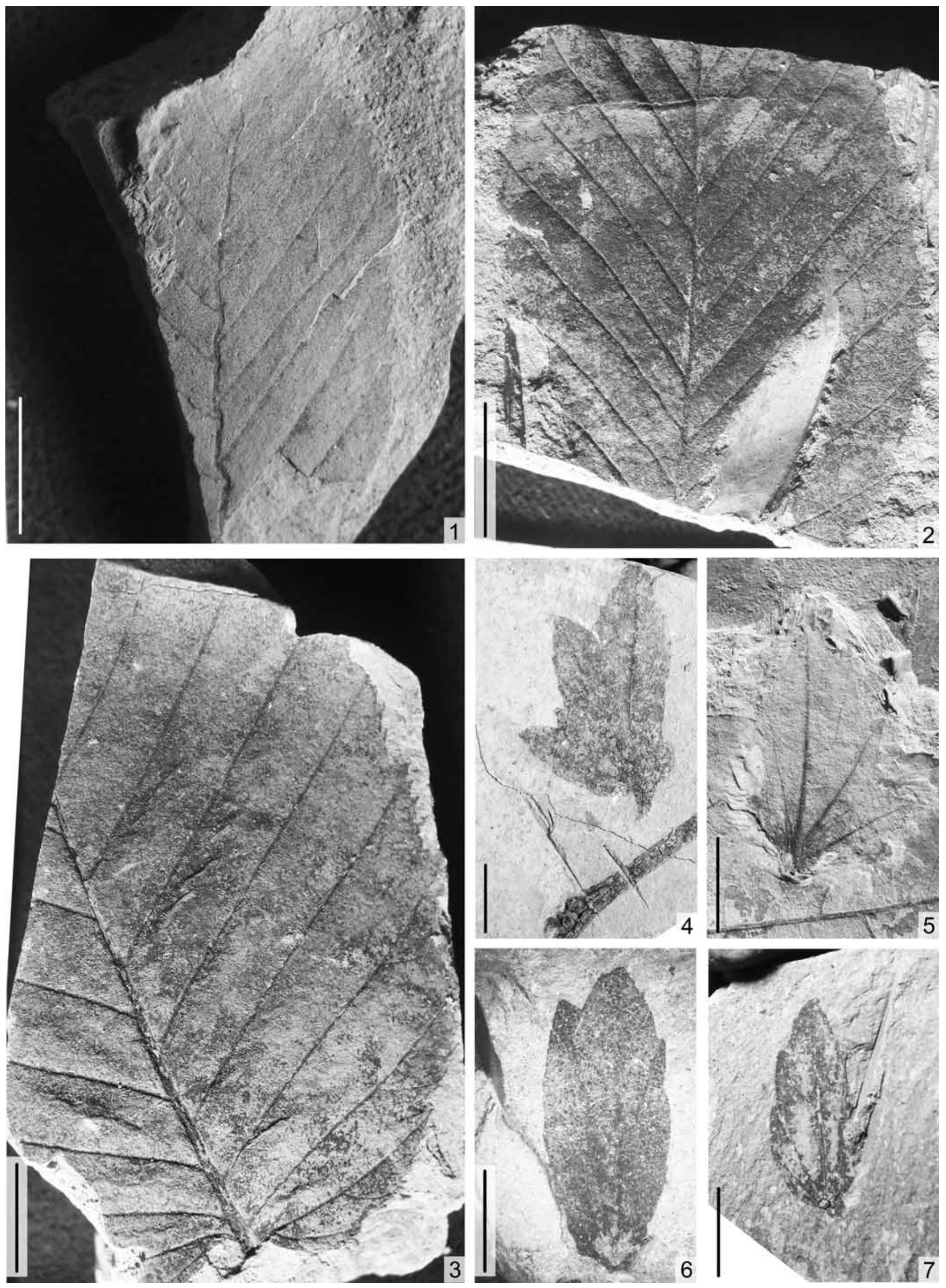

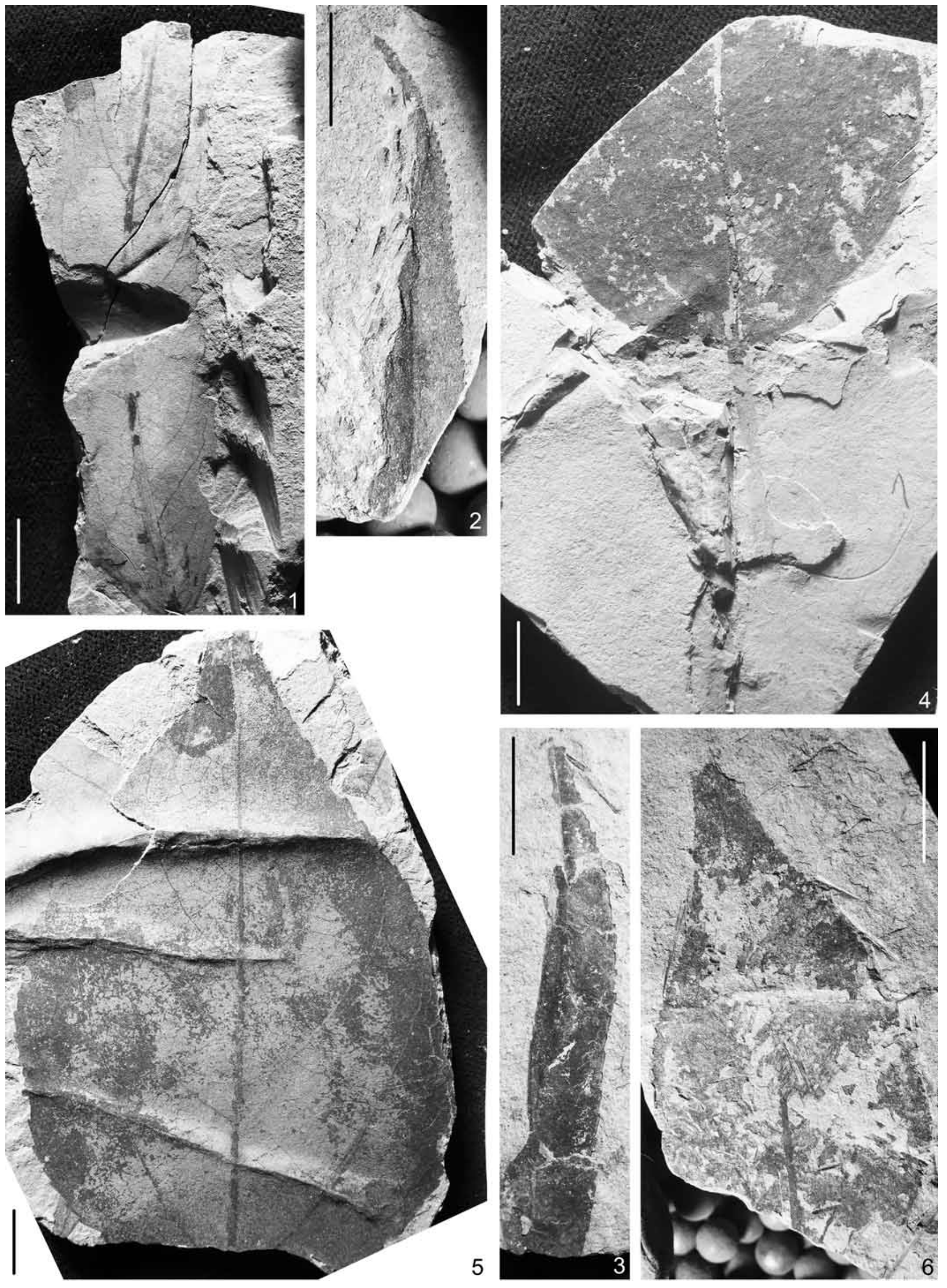
PLATE 18
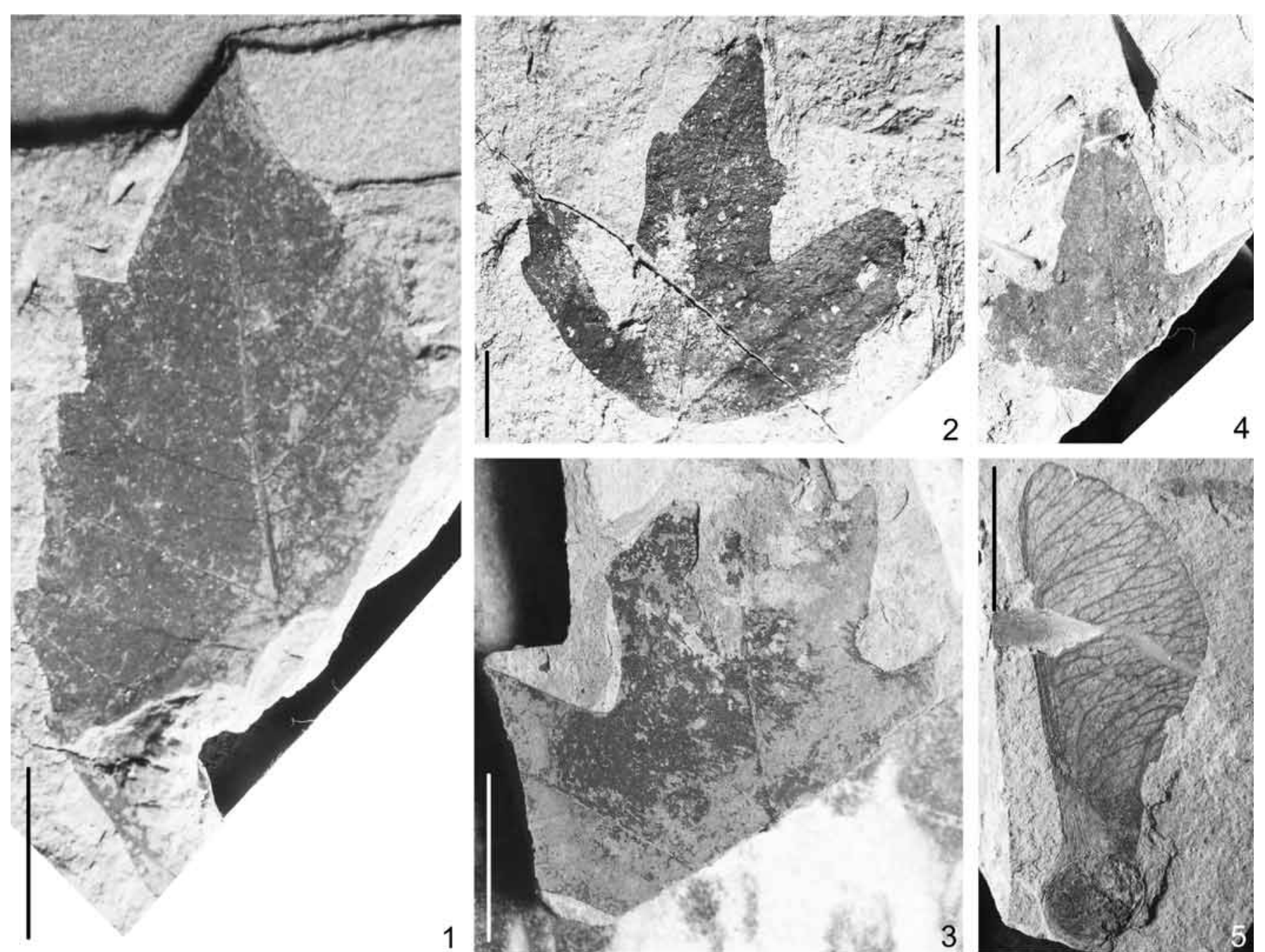

1
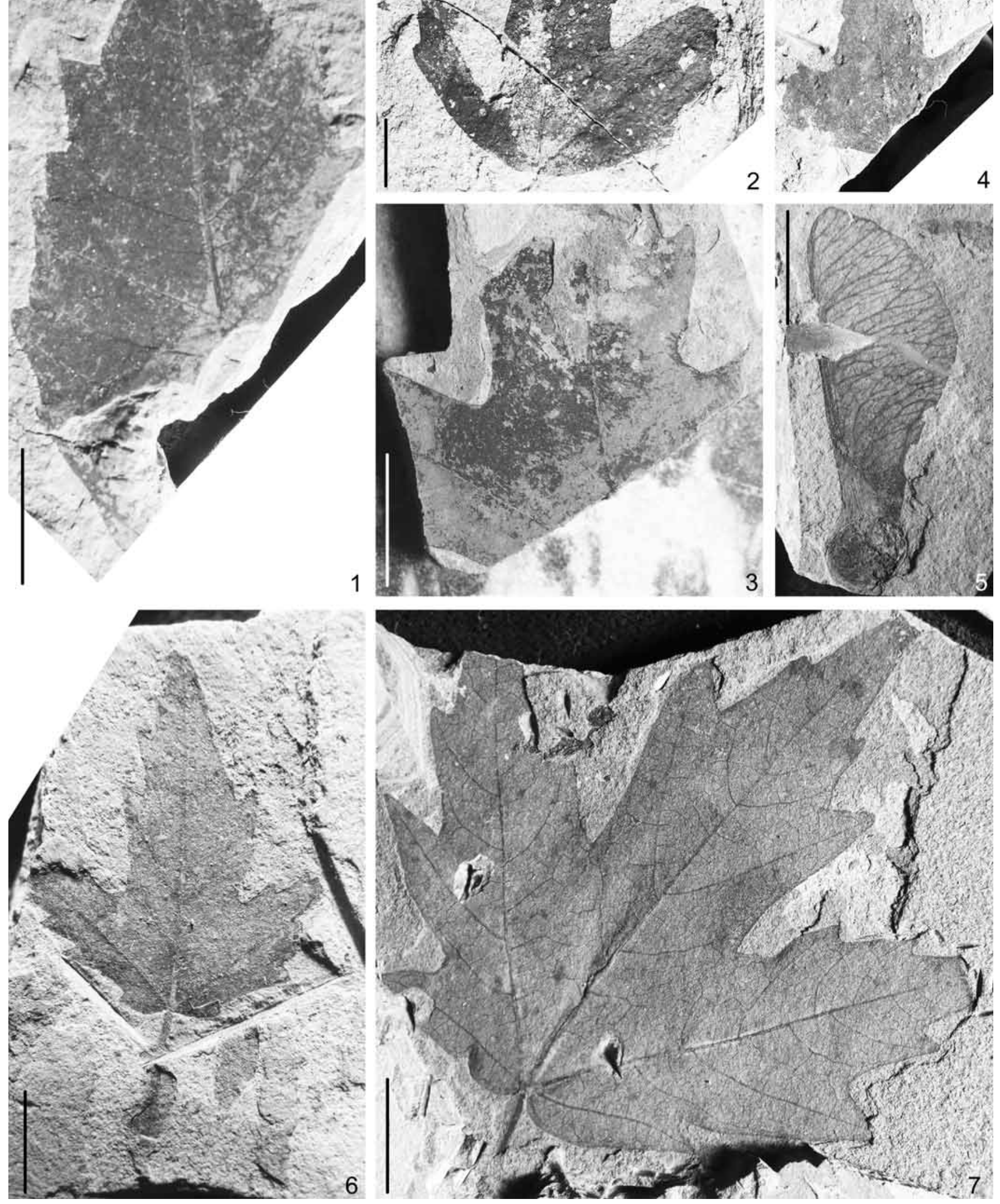
PLATE 19
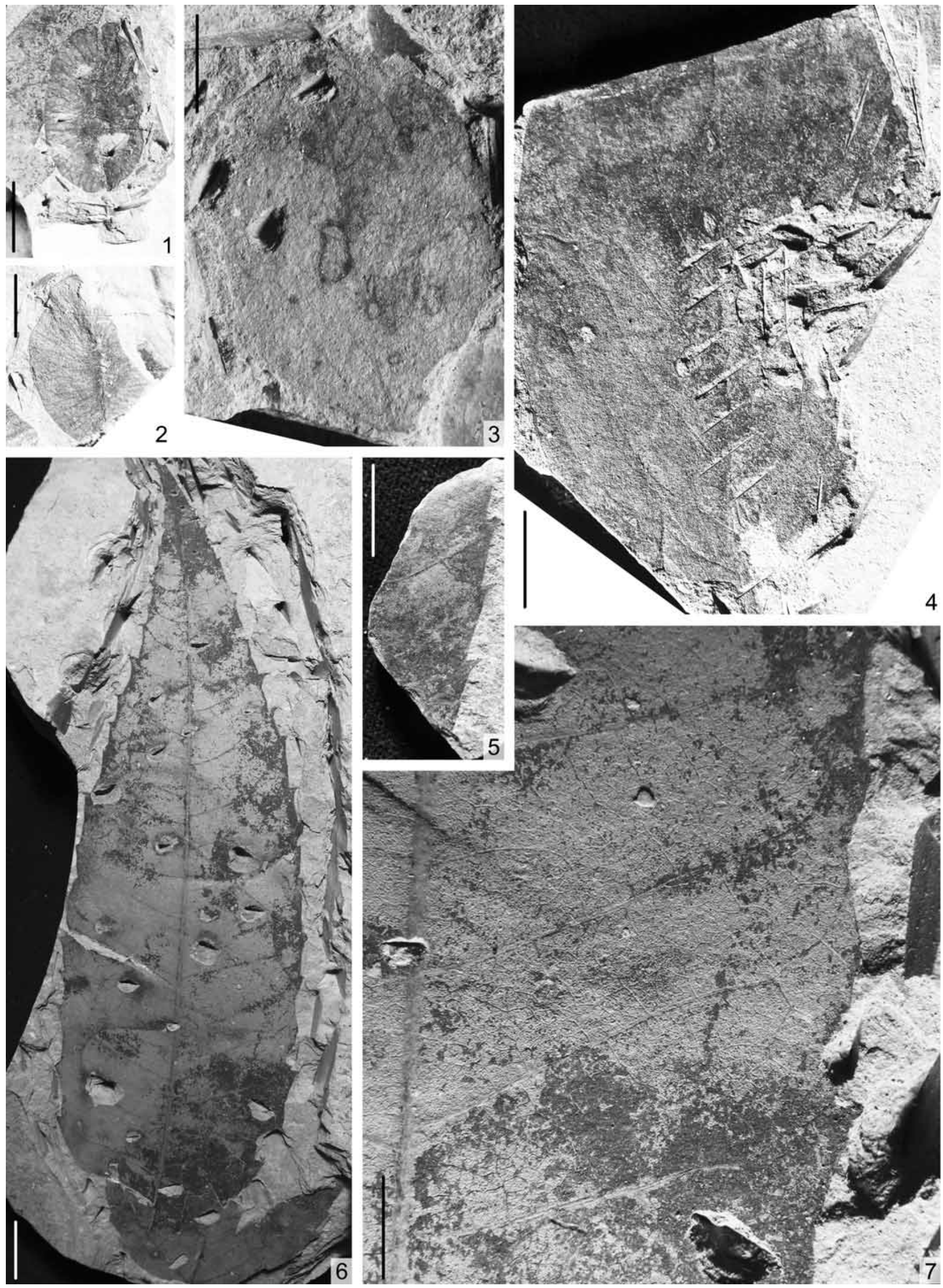

4
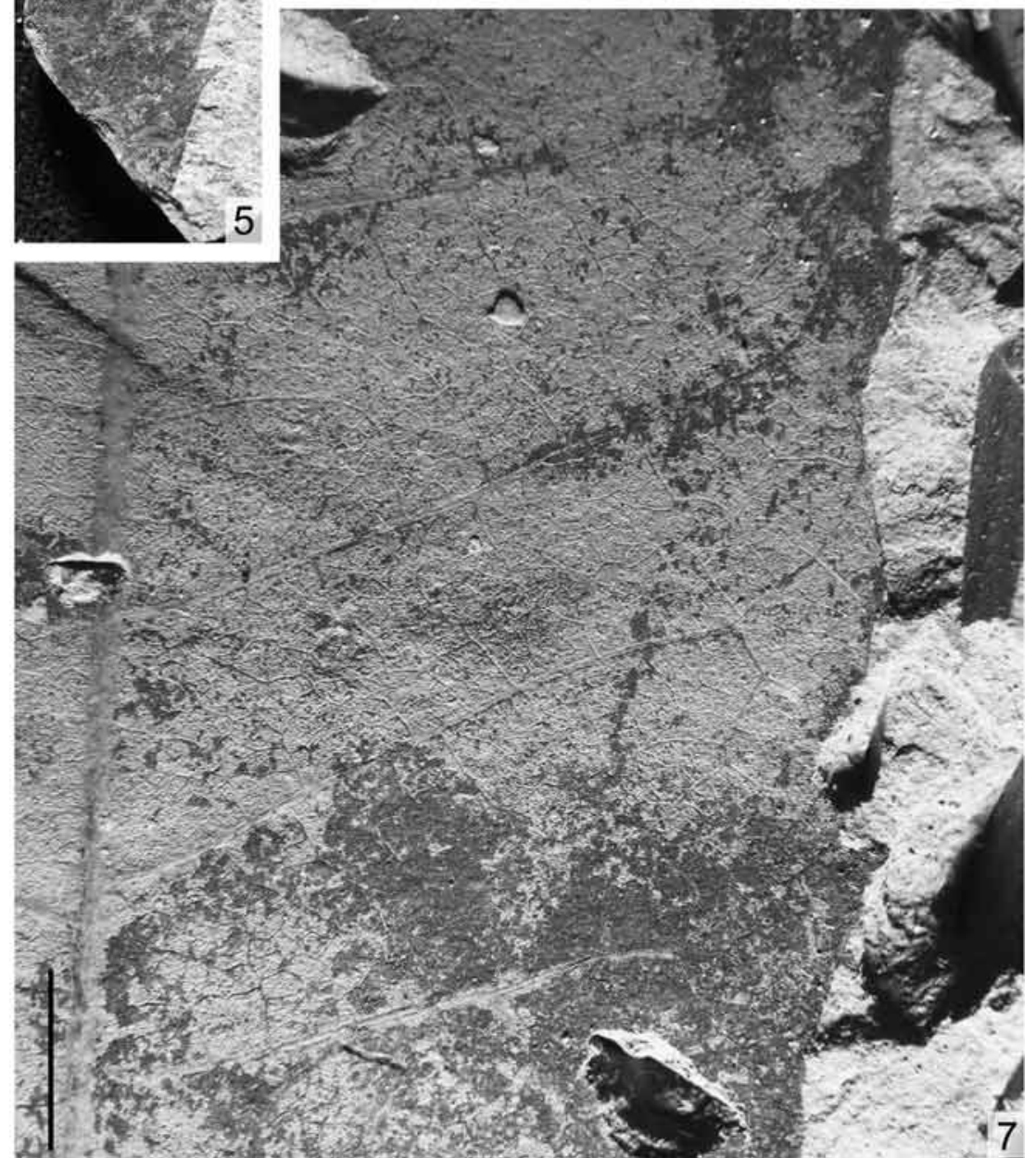
PLATE 20
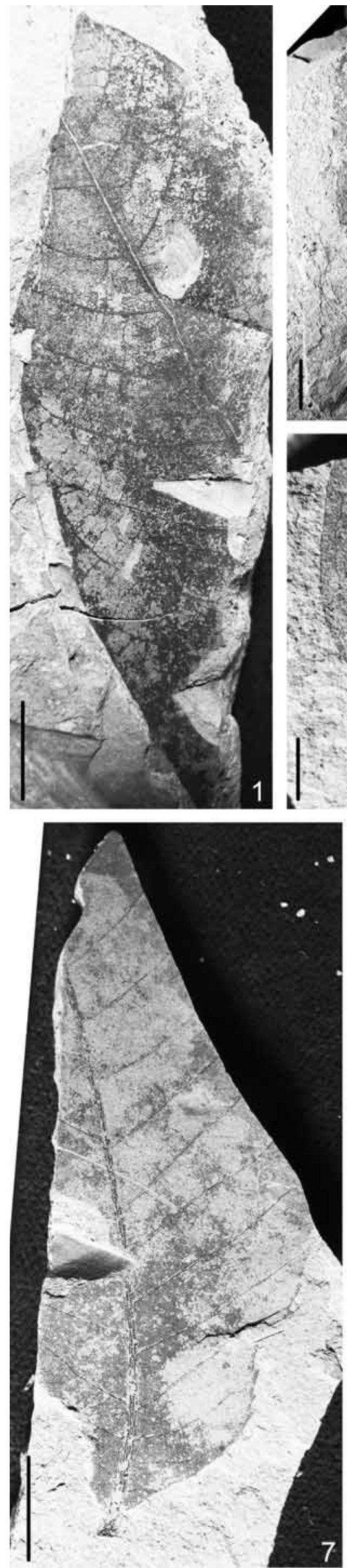
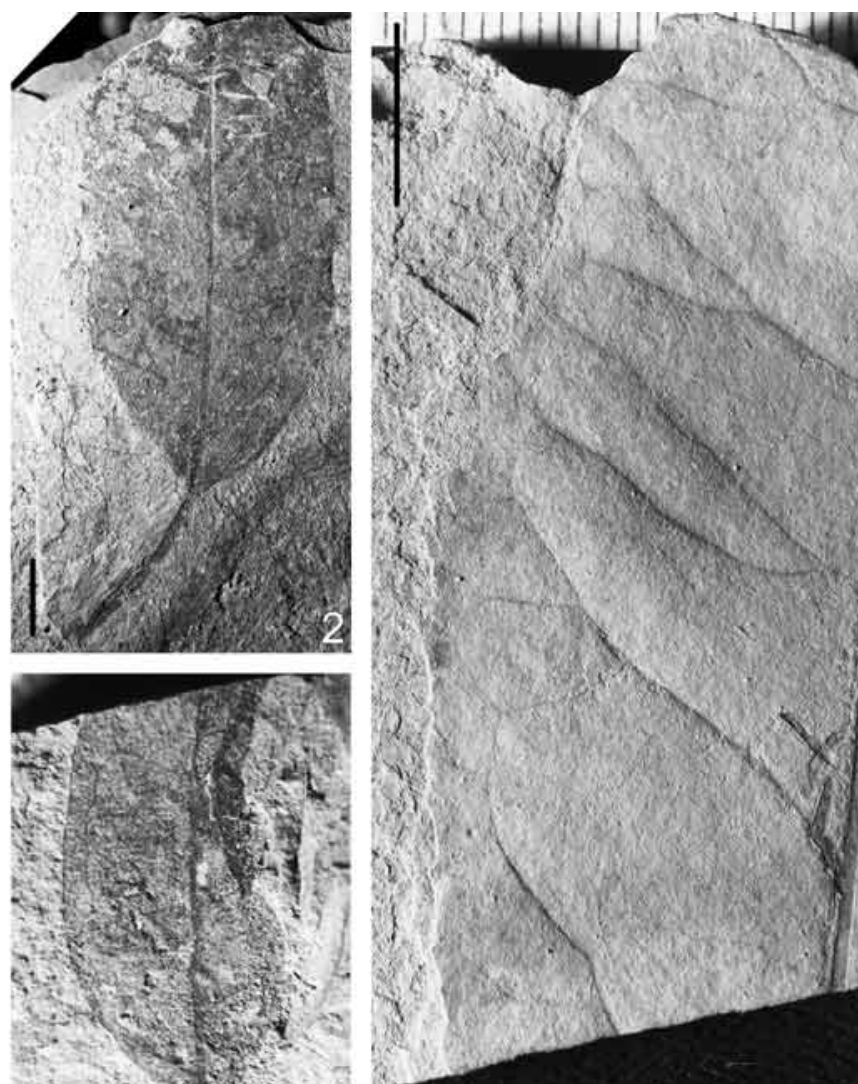

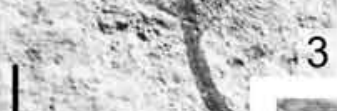
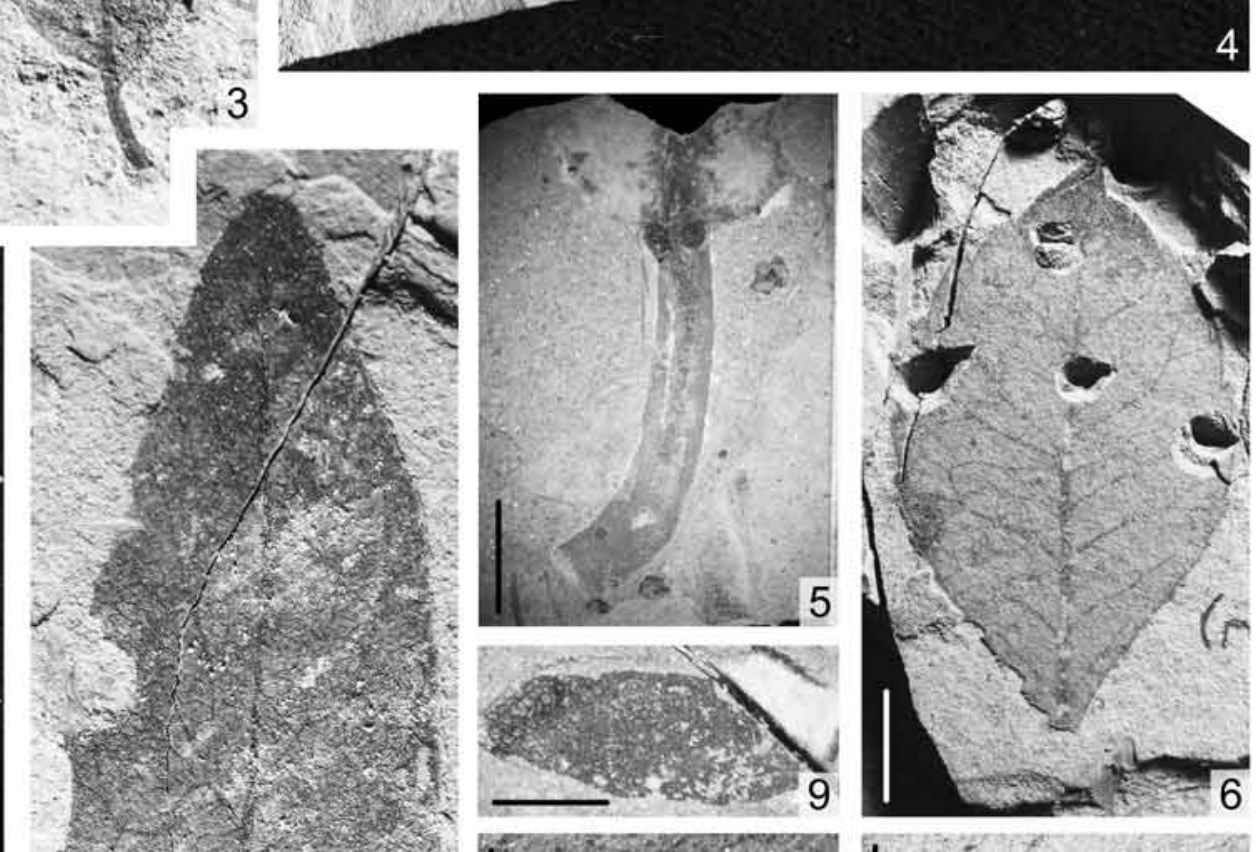

$2 x^{2}+2$
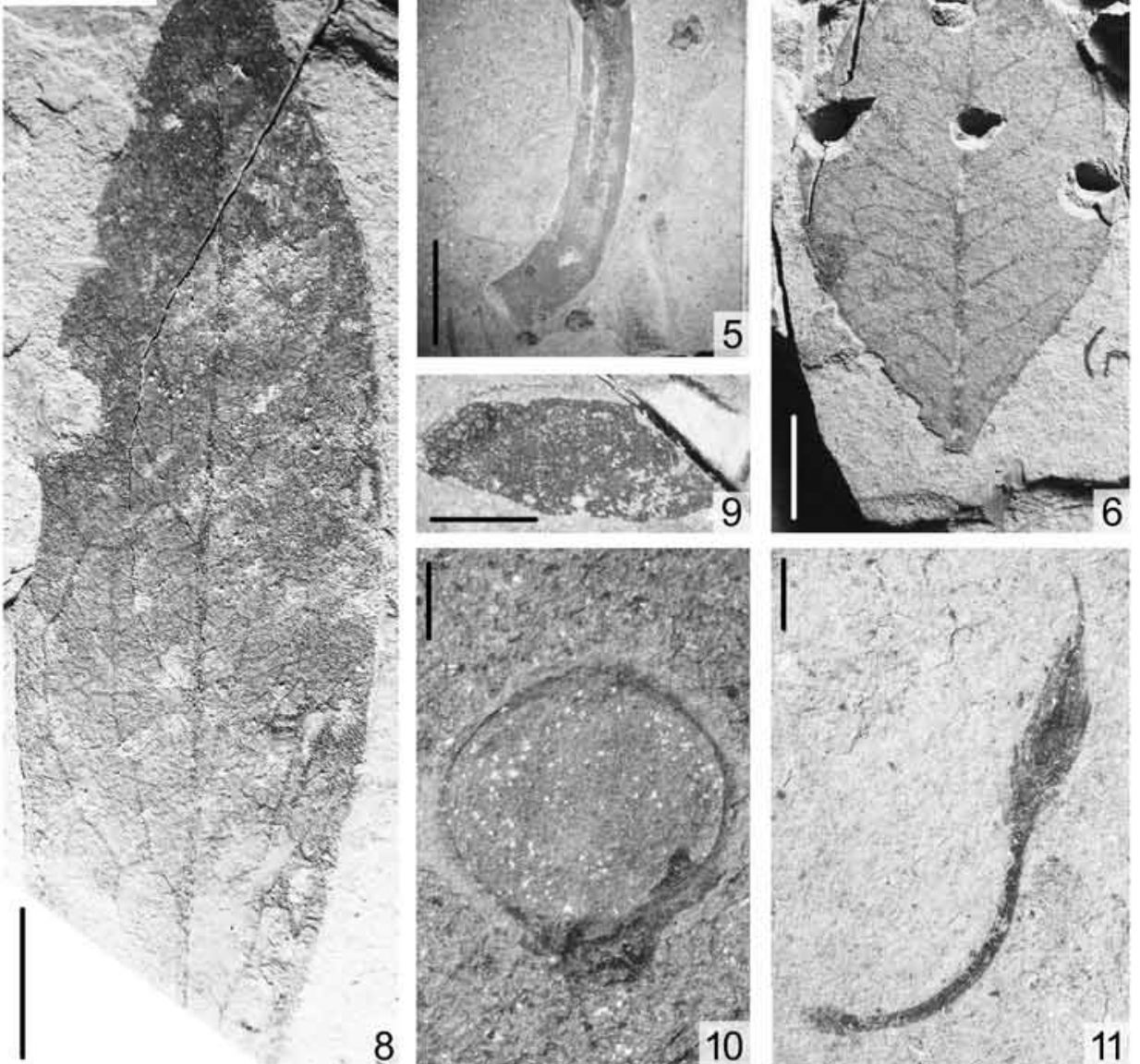


\section{PLATE 21}

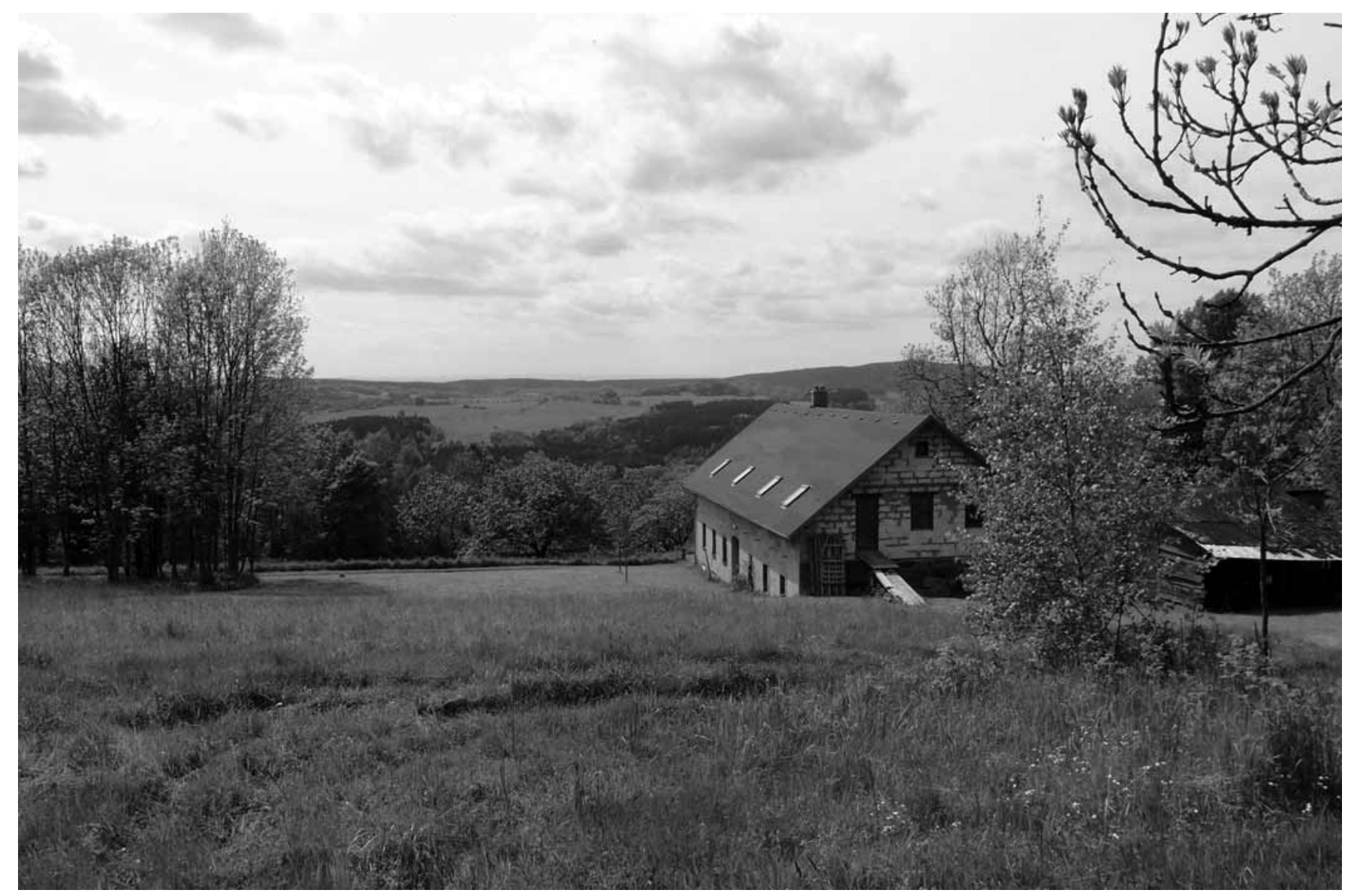

